\title{
Interstitial Deletions Generating Fusion Genes
}

\author{
IOANNIS PANAGOPOULOS ${ }^{1}$ and SVERRE HEIM ${ }^{1,2}$ \\ ${ }^{1}$ Section for Cancer Cytogenetics, Institute for Cancer Genetics and Informatics, \\ The Norwegian Radium Hospital, Oslo University Hospital, Oslo, Norway; \\ ${ }^{2}$ Institute of Clinical Medicine, Faculty of Medicine, University of Oslo, Oslo, Norway
}

\begin{abstract}
A fusion gene is the physical juxtaposition of two different genes resulting in a structure consisting of the head of one gene and the tail of the other. Gene fusion is often a primary neoplasia-inducing event in leukemias, lymphomas, solid malignancies as well as benign tumors. Knowledge about fusion genes is crucial not only for our understanding of tumorigenesis, but also for the diagnosis, prognostication, and treatment of cancer. Balanced chromosomal rearrangements, in particular translocations and inversions, are the most frequent genetic events leading to the generation of fusion genes. In the present review, we summarize the existing knowledge on chromosome deletions as a mechanism for fusion gene formation. Such deletions are mostly submicroscopic and, hence, not detected by cytogenetic analyses but by array comparative genome hybridization (aCGH) and/or high throughput sequencing (HTS). They are found across the genome in a variety of neoplasias. As tumors are increasingly analyzed using aCGH and HTS, it is likely that more interstitial deletions giving rise to fusion genes will be found, significantly impacting our understanding and treatment of cancer.
\end{abstract}

A fusion gene is defined as the physical juxtaposition of two different genes resulting in a chimeric structure consisting of the head of one gene and the tail of the other. It is an

This article is freely accessible online.

Correspondence to: Ioannis Panagopoulos, Section for Cancer Cytogenetics, Institute for Cancer Genetics and Informatics, The Norwegian Radium Hospital, Oslo University Hospital, Montebello, PO Box 4954 Nydalen, NO-0424 Oslo, Norway. Tel: +47 22782362, e-mail: ioannis.panagopoulos@rr-research.no

Key Words: Interstitial deletion, chromosome, cytogenetics, fusion gene, review. important class of mutations in both benign and malignant neoplasms where they often constitute the primary tumorigenic event (1-5). Clinically, fusion gene-detection may play a key role in the accurate diagnosis and sub-classification of cancers, may have prognostic significance, and the novel genes may even be the target of molecular therapy (6-9). Thus, they are key to an increased understanding of neoplastic processes and may serve as the ultimate biomarker. As such, they have attracted much attention.

Fusion genes have been detected in hematologic neoplasms as well as in both benign and malignant mesenchymal, epithelial, and other solid tumors (10, 11). During 1982-1988, 10 fusion genes were identified, followed by 162 during the next decade (1990-99). In the last update (January 15, 2021) of the "Mitelman Database of Chromosome Aberrations and Gene Fusions in Cancer", the number of fusion genes had risen to 32,618 (12). The list is certainly going to become longer as more tumor samples are investigated using high throughput sequencing methodologies (10). However, many of the fusion genes detected by these techniques alone, i.e. without subsequent, meticulous verification by other methods, are likely to represent stochastic events without any pathogenetic significance (13).

Chromosomal translocations, and to a lesser extent inversions, have traditionally been viewed as the most common genetic mechanisms whereby fusion genes are generated. The existence of such events has been known since the 1980s and the field has been repeatedly and extensively reviewed (1-5, 7, 14-17).

In contrast, unbalanced genomic rearrangements leading to loss of material, in particular terminal and interstitial chromosomal deletions, have mostly been pathogenetically associated with loss of tumor suppressor genes (11, 18-20). In the 1970 s, the detection of a constitutional interstitial deletion of chromosome band $13 \mathrm{q} 14$ in some patients with retinoblastoma was key to Knudson's two-hit model of suppressor gene-mediated tumorigenesis and crucial for the 
subsequent discovery of $R B 1$, the classical tumor suppressor gene (21-27). Another example was the interstitial deletion of chromosome band 9p21 detected in many types of cancer, but particularly in acute lymphoblastic leukemia, which results in loss of the cyclin dependent kinase inhibitor $2 \mathrm{~A}$ and 2B genes (CDKN2A and CDK2NB) (28-31). Chromosome deletions resulting in the loss of an important allele and, consequently, reduced levels of protein in the cells lacking that allele (haploinsufficiency) may also contribute to cancer development, even in the absence of subsequent loss of the second allele $(20,32-34)$.

A less known consequence of interstitial chromosomal deletions is the formation of fusion genes. In the present review, we discuss this genetic mechanism, i.e. the fusion genes that develop through it, and the neoplastic diseases in which this appears to be preferred.

\section{Genes at the Rims of Interstitial Deletions May Fuse to Form Chimeric Genes/Transcripts}

The principle for the formation of a fusion gene by interstitial deletion is the same as that for a translocationgenerated fusion. The deletion starts within the 5 '-end of one gene and finishes within the 3'-end of another, its fusion partner. Both genes are transcribed in the same orientation, i.e. from telomere to centromere or from centromere to telomere. Thus, juxtaposition of the two genes by removal of the chromosome segment between them results in a chimeric structure consisting of the head of one gene and the tail of the other (Figure 1A). Depending on the size of the deletion, loss of gene loci between the fusion partners may or may not accompany the fusion gene formation.

It is important to note that a fusion gene generated by a deletion could also be formed by a translocation between homologous chromosomes if the breaks and recombinations are the same as those for the deletion (Figure 1B). For example, deletion in chromosome bands 1q22-23 breaks the genes lamin $\mathrm{A} / \mathrm{C}$ (LMNA in 1q22) and neurotrophic receptor tyrosine kinase 1 (NTRK1 in 1q23.1), both of which are transcribed from centromere to telomere, to generate the LMNA-NTRK1 fusion gene in many malignancies (see below). The same LMNA-NTRK1 fusion gene can also be formed by a $\mathrm{t}(1 ; 1)(\mathrm{q} 22 ; \mathrm{q} 23)$ chromosome translocation.

Most fusion genes have been detected using high throughput sequencing technologies. In fact, most were found as fusion transcripts in RNA sequencing analyses and were subsequently reported as fusion genes (35-39). For the majority of cases, no chromosome banding or other cytogenetic analysis, no fluorescence in situ hybridization (FISH), array comparative genome hybridization (aCGH), single nucleotide polymorphism (SNP) array, Southern blot or other methodologies were used to support this conclusion. As a consequence, no actual genomelevel confirmation exists that fusion gene formation has taken place in these situations, i.e. no structural DNA rearrangement leading to the junction of two different genes has been proven. In order to fill this "gap" between fusion transcripts and fusion genes, Prof. Mitelman decided in his database that "chromosome abnormalities giving rise to gene fusions identified through RNA sequencing are by default designated as translocations ( $\mathrm{t}$ ), unless shown to arise by other types of chromosome rearrangements (del, dup, ins, inv)" (12, 40, 41). By way of example, the "Mitelman Database of Chromosome Aberrations and Gene Fusions in Cancer" lists the transcript emanating from a fusion between the transcriptional repressor GATA binding 1 (TPRS1) gene from 8q23.3 and the pleomorphic adenoma gene 1 (PLAG1) from 8q12.1 (TRPS1-PLAG1 chimera), found by RNA sequencing in a uterine myxoid leiomyosarcoma and a soft tissue myoepithelial tumor, as being generated by a $\mathrm{t}(8 ; 8)(\mathrm{q} 12 ; \mathrm{q} 23)$ $(12,40,41)$. However, no direct evidence for the presence of such a translocation is provided in the articles describing the genetic analyses of the above-mentioned tumors (40, 41). By contrast, we recently examined a chondroid syringoma carrying a del(8)(q12q23) as the only cytogenetic aberration (42). Using aCGH, FISH, reverse transcription polymerase chain reaction (RT-PCR), and Sanger sequencing methodologies, we showed that a TRPS1-PLAG1 chimeric gene was generated by the deletion (42) (Figure 2).

Chimeric transcripts may also be formed at the transcription level. In that case, two independently transcribed, neighboring genes with the same orientation give rise to a single chimeric RNA which may code for a chimeric protein (43-46). Various names have been given for these chimeric transcripts such as readthrough transcripts, transcription induced chimeras, tandem RNA chimeras etc (47). They have been found in many mammals (48). Whether they should be viewed as genuine chimeric transcripts is still under discussion (43-50). An example involves the genes solute carrier family 45 member 3 (SLC45A3) and ETS Like 4 transcription factor (ELK4) which are both transcribed from telomere to centromere and map on $1 \mathrm{q} 32$ with a distance of $25 \mathrm{kbp}$ between them. The chimeric SLC45A3-ELK4 transcript, detected in prostate cancer, was found to be generated by cis-splicing between the two neighboring genes SLC45A3 and ELK4 without any actual rearrangement of DNA $(35,51-53)$. That chimera is designed as resulting from a $\mathrm{t}(1 ; 1)(\mathrm{q} 32 ; \mathrm{q} 32)$ in Mitelman's database (12).

With all these difficulties, caveats, and provisos in mind, we provide a chromosome-by-chromosome list of the unambiguous deletion-generated neoplasia-associated fusion genes that we have been able to ascertain from the relevant literature (Table I).

\section{Chromosome 1}

The SCL/TAL1 interrupting locus (STIL is also known as $S I L)$ maps on $1 \mathrm{p} 33$, is transcribed from centromere to telomere, and codes for a protein which is part of the 

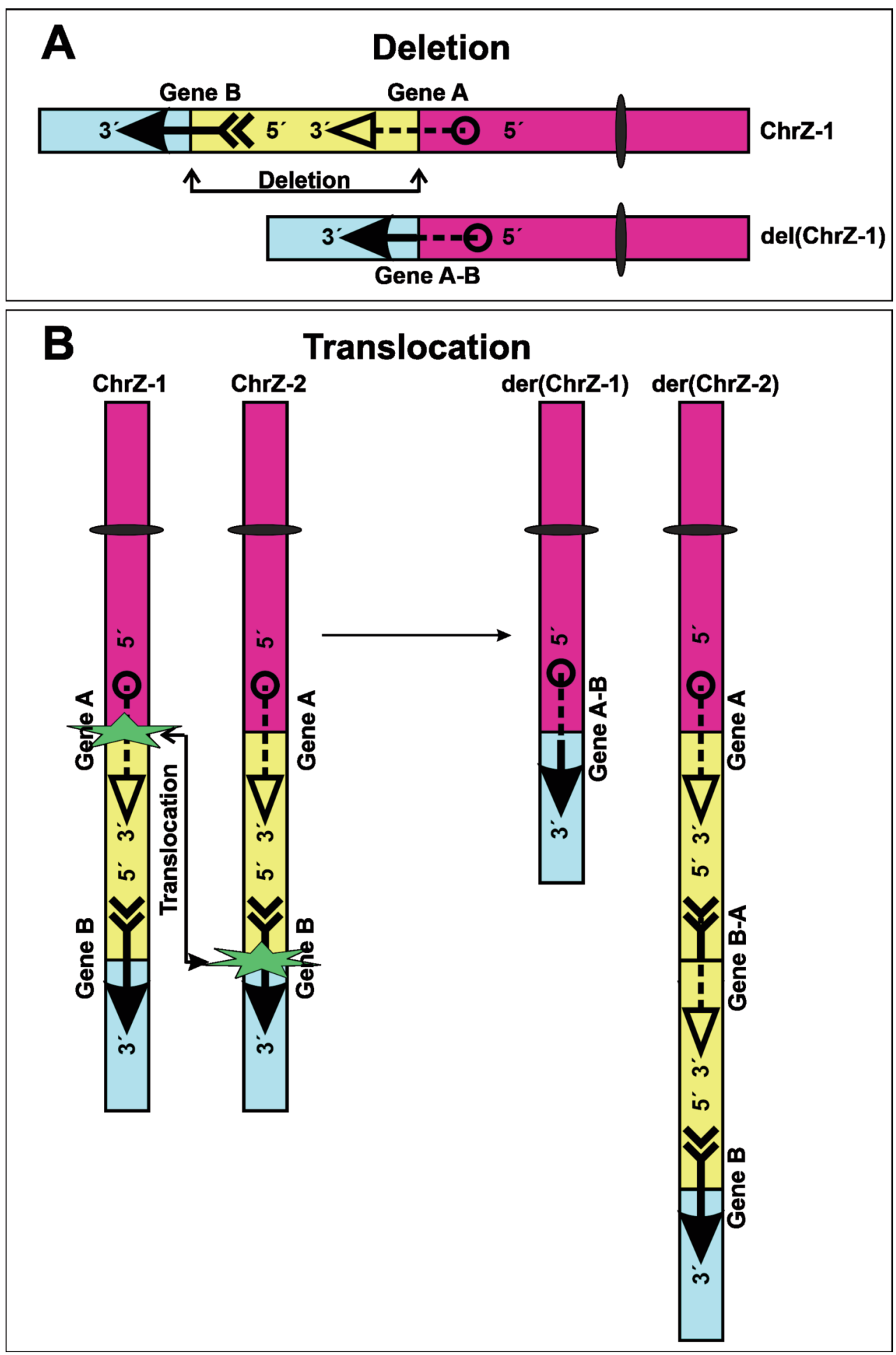

Figure 1. Formation of a fusion gene (Gene A-B) by an interstitial deletion and a chromosome translocation. (A) The deletion starts within Gene A and finishes within Gene B. Both genes are transcribed from centromere to telomere. The juxtaposition of the two genes by removal of the chromosome segment (yellow region) between them results in the chimeric Gene A-B consisting of the head (5'-end) of Gene A and the tail (3'end) of Gene B. Loss of gene loci mapping in the yellow region, between the fusion partners, accompanies the fusion gene formation. (B). Formation of Gene A-B fusion by chromosome translocation between the two homologous chromosomes ChrZ-1 and ChrZ-2. Gene A-B is formed on der(ChrZ1) whereas the reciprocal Gene B-A is formed on the $\operatorname{der}(\mathrm{ChrZ-2)}$ chromosome. Duplication of gene loci mapped in the yellow region accompanies the reciprocal Gene B-A formation. 


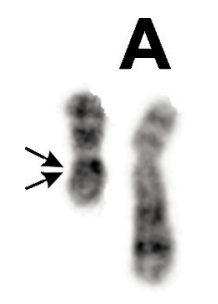

$\operatorname{del}(8) 8$

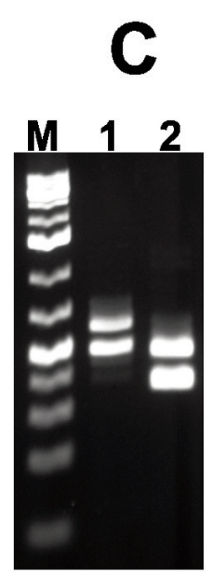

\section{B}

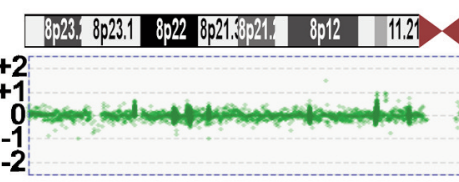

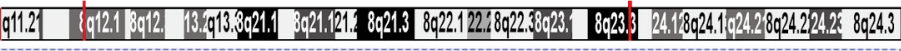

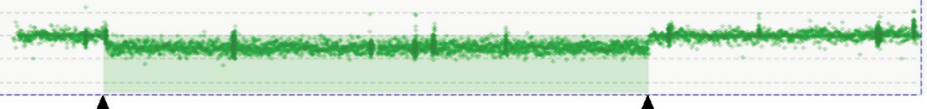

Chr8:57120365

Chr8:116661489
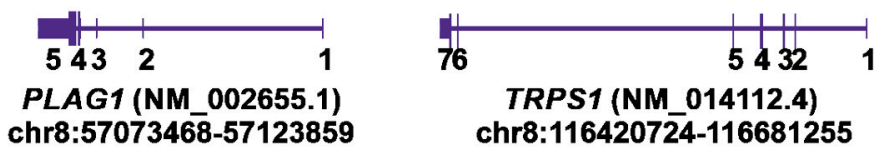

D

TRPS1 exon $1 \downarrow P L A G 1$ exon 2

T T C T T G AC GAT TAAT CAACAGRT T GC C T C T T G GK GC T GCC T

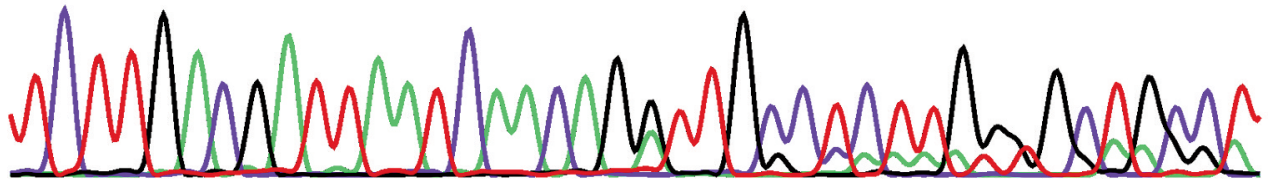

TRPS1 exon $1 \downarrow$ PLAG1 exon 3

T T C T T GACGAT TAATCAACA GATTG GCCAAAAT G G GAGGAT

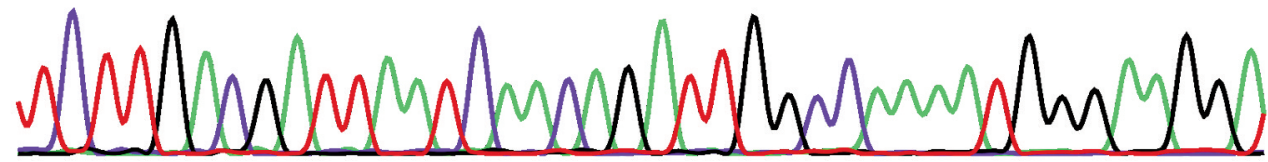

$\mathbf{E}$

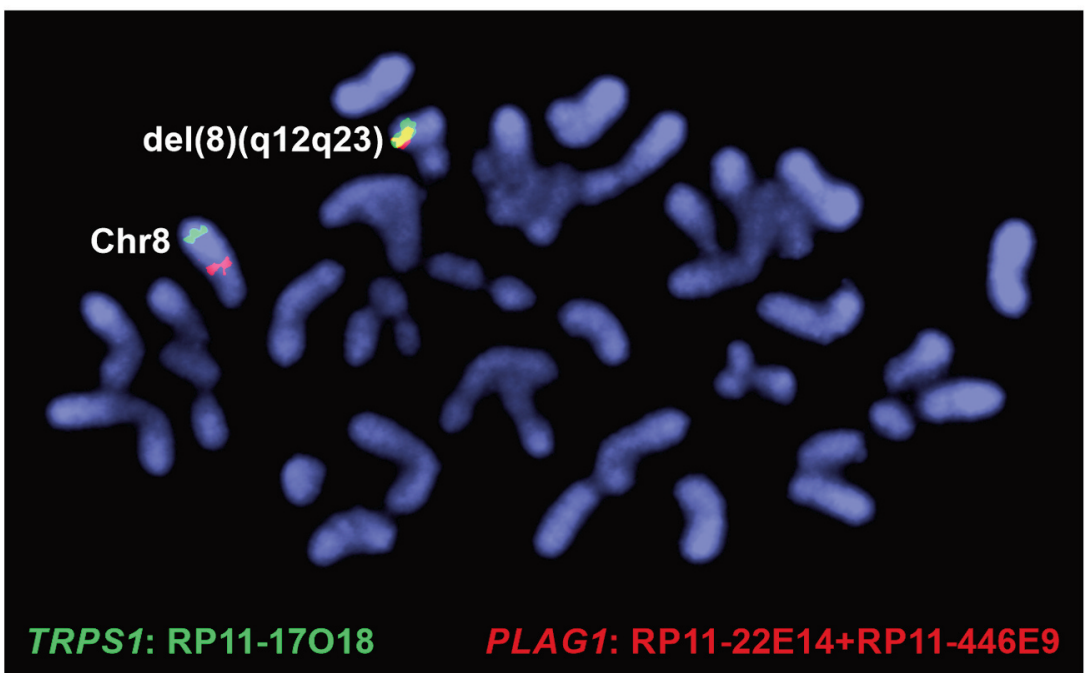

Figure 2. Identification of a TRPS1-PLAG1 fusion gene which is generated by the interstitial deletion del(8)(q12q23). (A) Partial karyotype showing the del(8)(q12q23) and the normal chromosome 8 (breakpoints are shown by arrows). (B) Array comparative genomic hybridization showing the deletion in the $q$ arm of chromosome 8. Based on the hg19 assembly, the deletion started at position Chr8:57120365 in intron1 of PLAG1 and ended at Chr8:116661489 in exon 1 of TRPS1. (C) Gel electrophoresis showing the amplified TRPS1-PLAG1 cDNA fragments. (D) Partial sequence chromatograms of the CDNA amplified fragment showing the junction positions of exon 1 of TRPS1 with exon 2 of PLAG1 and exon 1 of TRPS1 with exon 3 of PLAG1. E) FISH analysis on metaphase spreads with PLAG1 probe (red signal) and TRPS1 probe (green signal) showing that the TRPS1-PLAG1 fusion gene is on the del(8)(q12q23) (yellow signal). One copy of PLAG1 (red signal) and one of TRPS1 (red signal) are on chromosome 8. Data and figure are obtained from reference 42. 


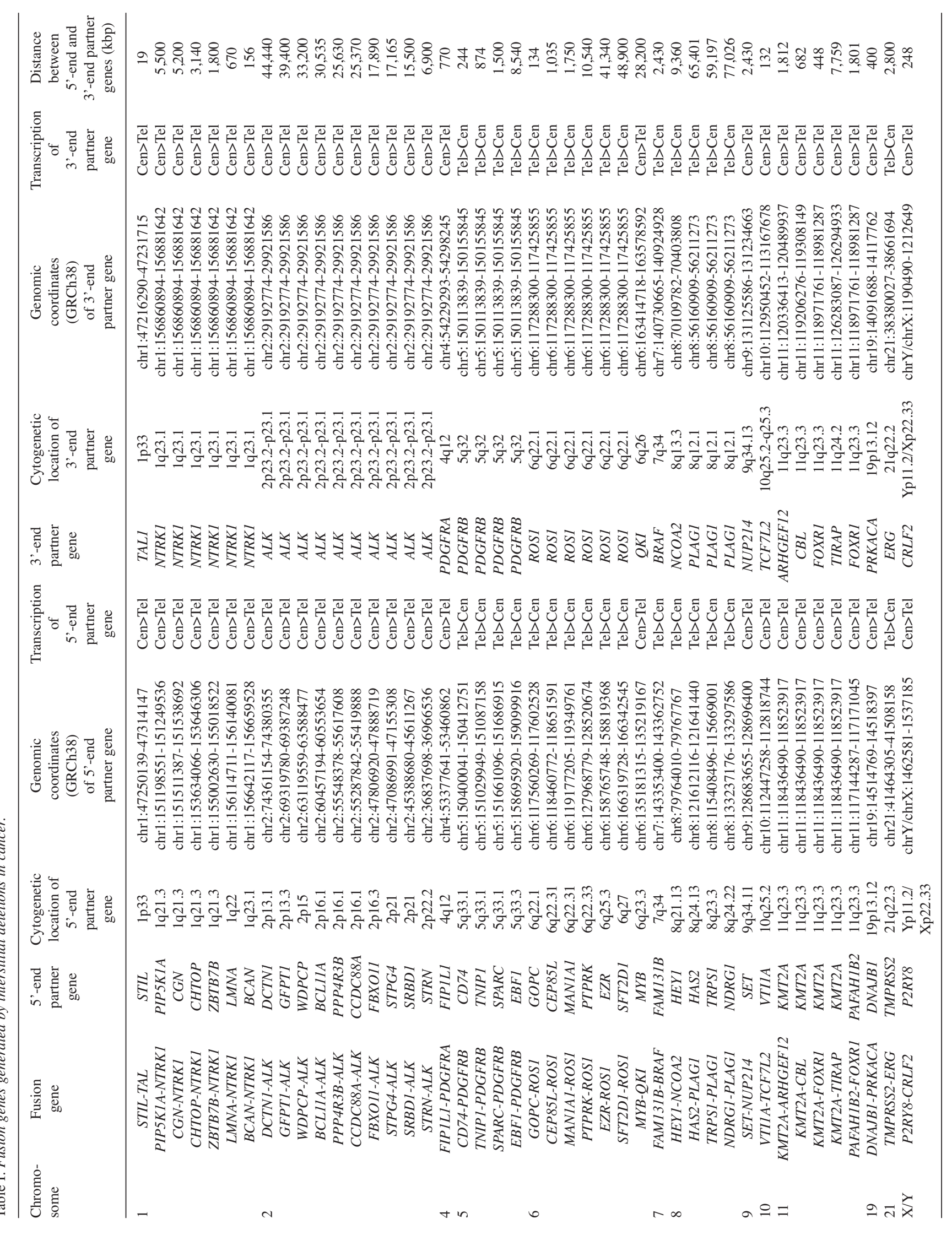


pericentriolar material surrounding the parental centrioles, which is essential for centriole duplication during the cell cycle (54). The T-cell acute leukemia 1 (TAL1 also known as $S C L$, tal-1) gene maps just $18 \mathrm{kbp}$ distal to $S T I L$, is transcribed from centromere to telomere and codes for a transcription factor that harbors the basic helix-loop-helix domain (bHLH) which is a protein dimerization and DNAbinding motif common to many eukaryotic transcription factors (55).

In 1990, two independent research groups working on Tlineage acute lymphoblastic leukemias detected an approximately $90 \mathrm{kbp}$ interstitial deletion in $1 \mathrm{p} 33$ which caused the 5'-untranslated part of STIL to fuse with the coding part of TALl $(56,57)$. The deletion placed the expression of TAL1 under the control of the STIL promoter, causing aberrant overexpression of the TAL1 protein $(56$, 57). To the best of our knowledge, this was the first description of a fusion gene resulting from an interstitial, submicroscopic deletion.

The STIL-TAL1 fusion gene has been reported in 15-25\% of pediatric and young adult T-lineage acute lymphoblastic leukemia (T-ALL) but much less frequently in older T-ALL patients (58-60). Compared to T-ALL patients without STILTAL1 fusions, those with the chimera have a higher white blood cell count at diagnosis, express CD2 on their leukemic cells and show a poor response to the steroid drug prednisone $(59,61,62)$. The prognosis of $S T I L-T A L 1$ fusionpositive leukemias has been reported as both better, poorer or about equal to that of other T-ALL groups $(59,61-64)$. In murine models, abnormal expression of TAL1 has been reported to result in the development of T-cell malignances $(65,66)$.

Fusion of the gene coding for lamin A and $\mathrm{C}$ (LMNA) with the gene coding for neurotrophic receptor tyrosine kinase 1 (NTRK1) was reported to occur as the result of a $750 \mathrm{kbp}$ interstitial deletion in chromosome bands 1q22-23 in a spitzoid melanoma (67). Both genes are transcribed from centromere to telomere. Subsequently, LMNA-NTRK1 fusion was also described in other neoplasias such as colon cancer, thyroid cancer, breast cancer, cholangiocarcinoma, soft tissue sarcoma, and uterine sarcoma (68-80). The LMNA-NTRK1 codes for a chimeric tyrosine kinase. Patients with this fusion can be treated with kinase inhibitors such as crizotinib, entrectinib, and larotrectinib with significant clinical response $(71,72,79,81-85)$.

In the 1q21-23 chromosomal region, 15 fusion genes involving NTRK1 have been reported. Based on the orientation of the transcription (from centromere to telomere), interstitial deletions come across as the probable cause of fusions between NTRK1 (3'-fusion partner) and zinc finger and BTB domain containing 7B $(Z B T B 7 B)$, brevican $(B C A N)$, chromatin target of protein arginine methyltransferase 1 (CHTOP), cingulin $(C G N)$, platelet endothelial aggregation receptor 1
(PEAR1), or phosphatidylinositol-4-phosphate 5-kinase type 1 alpha (PIP5K1A). The fusions have been found in various tumors of the brain, breast, bladder, and neuroendocrine cells (75, 80, 86-89). Most fusions have been detected using high throughput sequencing methodologies. Cytogenetic, FISH, aCGH, or any other data confirming the said deletions at the genomic level are lacking.

Using CRISP-Cas9, Cook et al. (90) generated a microdeletion leading to a Bcan-Ntrk1 fusion gene in mice. The mice developed high-grade gliomas which responded to the Ntrk1 inhibitor entrectinib. In general, patients whose cancers carry NTRK1 fusion genes have responded satisfactorily to treatment with tyrosine kinase inhibitors $(85,91-95)$.

\section{Chromosome 2}

The anaplastic lymphoma kinase $(A L K)$ gene maps to $2 \mathrm{p} 23$ (position chr2:29,192,774-29,921,586) and is transcribed from centromere to telomere. More than $20 A L K$-chimeras have been reported in which the $A L K 5^{\prime}$ '-fusion partner comes from another gene which also resides on the short arm of chromosome 2. In 10 of these $A L K$-chimeras, the 5'fusion partner maps proximal to $A L K$ (i.e. closer to chromosome 2 centromere) and is also transcribed from the centromere towards the telomere (Table I). Thus, an interstitial deletion could be the genomic mechanism behind the generation of these chimeras.

Fusion of the coiled-coil domain-containing protein $88 \mathrm{~A}$ (CCDC88A) gene with $A L K$, giving a CCDC88A-ALK chimera, was found in an anaplastic ependymoma of an 8month-old girl. An interstitial deletion del(2)(p16p23) was seen by G-banding examination of the tumor cells and confirmed by FISH. Genomic PCR showed that the deletion started within intron 12 of CCDC88 (2p16.1) and ended within intron 19 of $A L K(2 \mathrm{p} 32.2)$ (96).

$A L K$-fusions were detected with the genes dynactin 1 (DCTN1) in uterine inflammatory myofibroblastic tumor and pancreatic ductal adenocarcinoma (DCTN1-ALK chimera) $(97,98)$, glutamine:fructose-6-phosphate amidotransferase 1 (GFPT1) in medullary thyroid cancer (GFPT1-ALK chimera) (99), WD repeat-containing planar cell polarity effector $(W D P C P)$ in lung adenocarcinoma (WDPCP-ALK chimera) (100), BAF chromatin remodeling complex subunit BCL11A in lung adenocarcinoma (BCL11A-ALK chimera) $(101,102)$, S1 RNA binding domain 1 (SRBD1) in lung adenocarcinoma (SRBD 1-ALK chimera) $(103,104)$, and striatin $(S T R N)$ in lung adenocarcinoma, malignant peritoneal mesothelioma, and thyroid carcinoma (STRN-ALK chimera) (105-108). These were true chimeric genes resulting from DNA rearrangements, possibly deletions between the 5'-fusion partner and $A L K$ (the 3'partner). In all the above-mentioned fusion genes, the genomic breakpoint in $A L K$ was within the 1932 bp long intron 19 of the gene. 
Irrespective of the 5'-fusion partner gene, all $A L K$ chimeras seem to code for chimeric protein tyrosine kinases (109). Patients whose tumors carry $A L K$-chimeras, respond well to treatment with ALK inhibitors (110-115). More specifically, patients whose tumors carry the fusions DCTN1$A L K, B C L 11 A-A L K, S R B D 1-A L K, S T P G 4-A L K$, and STRN$A L K$ have reportedly shown excellent response to ALK inhibitors such as Crizotinib, Ceritinib, and Alectinib (98, 101-103, 105-107, 116).

\section{Chromosome 4}

The factor interacting with PAPOLA and CPSF1 (FIPILI) gene and the platelet derived growth factor receptor alpha (PDGFRA) gene both map to chromosome band $4 \mathrm{q} 12$ and are transcribed from centromere to telomere. The distance between them is $800 \mathrm{kbp}$. FIP1L1 codes for a subunit of the cleavage and polyadenylation specificity factor complex that polyadenylates the 3' end of mRNA precursors (117). PDGFRA codes for a cell surface tyrosine kinase receptor for members of the platelet-derived growth factor family (118-120). PDGFRA together with its paralog gene platelet derived growth factor receptor beta $(P D G F R B)$, and the genes colony stimulating factor 1 receptor $(C S F R 1)$, KIT proto-oncogene receptor tyrosine kinase $(K I T)$, and fms related receptor tyrosine kinase 3 (FLT3) code for the class III family of receptor tyrosine kinases that have important roles in leukemo- and tumorigenesis (120-124).

In 2003, the FIPIL1-PDGFRA fusion gene was, as a result of an $800 \mathrm{kbp}$ interstitial chromosomal deletion in $4 \mathrm{q} 12$, detected in nine out of 16 patients with hypereosinophilic syndrome (125). FIP1L1-PDGFRA codes for a chimeric, constitutively active tyrosine kinase which consists of the first 233 amino acids of FIP1L1 and the last 523 amino acids of PDGFRA. Imatinib inhibits tyrosine phosphorylation by the FIP1L1-PDGFRA fusion protein (125). Nowadays, the World Health Organization's "Classification of tumours of haematopoietic and lymphoid tissues" lists, under the category "Myeloid/lymphoid neoplasms with eosinophilia and rearrangement of PDGFRA, PDGFRB, or FGFR1, or with PCM1-JAK2", the new subgroup "Myeloid/lymphoid neoplasms with PDGFRA rearrangement" in which FIP1L1PDGFRA is the most commonly detected gene fusion (126128). Patients with this disease usually respond well to imatinib $(129,130)$.

\section{Chromosome 5}

The PDGFRB gene maps to $5 \mathrm{q} 32$ and is transcribed from telomere to centromere. It encodes, similarly to its homologous PDGFRA gene, a cell surface tyrosine kinase receptor for members of the platelet-derived growth factor family $(119,120,123,124)$. In 1994, Golub et al. reported that the $\mathrm{t}(5 ; 12)(\mathrm{q} 33 ; \mathrm{p} 13)$ chromosome translocation sometimes seen in chronic myelomonocytic leukemia results in fusion of the ETS variant transcription factor 6 gene (ETV6, also known as TEL) from $12 \mathrm{p} 13$ with $P D G F R B$ (131). According to the January 15, 2021 version of the Mitelman Database of Chromosome Aberrations and Gene Fusions in Cancer, 49 PDGFRB chimeras have been reported, most of them in hematologic malignancies (12). The consequence of the $P D G F R B$ fusions is constitutive activation of the PDGFRB tyrosine kinase $(120,123)$. Patients with hematologic malignancies bearing PDGFRB chimeras can be successfully treated with imatinib (132-140).

The genes EBF transcription factor 1 ( $E B F 1$ on $5 \mathrm{q} 33.3)$, CD74 molecule (CD74 on $5 \mathrm{q} 33.1$ ), secreted protein acidic and cysteine rich (SPARC on 5q33.1), and TNFAIP3 interacting protein 1 (TNIP1 on $5 \mathrm{q} 33.1)$ are transcribed from telomere to centromere and have been found to fuse as 5'end partner genes with $P D G F R B$ (Table I). The EBFI$P D G F R B$ chimera, which is found in B-lineage acute lymphoblastic leukemia, in the majority of cases results from an 8.6 Mbp interstitial deletion, $\operatorname{del}(5)(\mathrm{q} 32 \mathrm{q} 33.3)$, with breakpoints within the EBFI and PDGFRB genes $(132,133$, 141-143). In very few cases, a chromosome translocation has instead been shown to generate the EBF1-PDGFRB chimera (142). The TNIP1-PDGFRB chimera results from a $900 \mathrm{kbp}$ interstitial deletion with breakpoints located within TNIP1 and PDGFRB $(6,144-146)$.

No information exists about DNA rearrangements behind the formation of the CD74-PDFGRB and SPARC-PDGFRB chimeras found in a patient with B-ALL and a case of lipofibromatosis, respectively $(147,148)$. CD74 and SPARC are located $240 \mathrm{~kb}$ and $1.5 \mathrm{Mbp}$ distal to $P D G F R B$, respectively. Since both genes are transcribed from telomere to centromere, as is $P D G F R B$, and since both are distal to $P D G F R B$, we see it as probable that both fusions are the product of interstitial deletions.

\section{Chromosome 6}

The ROS proto-oncogene 1 , receptor tyrosine kinase (ROS1) gene maps on 6q22.1, is transcribed from telomere to centromere, and codes for a tyrosine kinase receptor with similarities to the Drosophila sevenless tyrosine kinase receptor (149-155). Neither the expression nor the cellular function of ROS1 has been well studied but the gene seems to be widely expressed. Examining the expression of ROS1 in 45 different human cell lines, the majority from various neoplasias, Birchmeier et al. (152, 155-158) found high-level expression in glioblastoma-derived cell lines but no to very low expression in the remainder. Further studies have shown ectopic expression of ROS1 also in other brain tumors (152, 155-158). ROS1 chimeras have been reported in various types of cancer, more and more as tumors are increasingly being 
screened for fusion genes/transcripts. In 2016, a review of ROS1 fusions in cancer reported 26 genes as having been found to fuse with ROS1 (159) whereas a similar recent review reported the number of ROSI fusion partners to be 54 (160). In 2020, the year before the review by Drilon et al. (160) was published, another 14 novel ROS1 fusion partner genes were added to the list (161-165), raising the total currently known number of ROS1 chimeras to 68 . Regardless of their large number and variability, ROS1 chimeras encode chimeric ROS1 proteins which are constitutively active kinases and which, consequently, may be targets for treatment with kinase inhibitors $(13,160,166-171)$.

In 2003, Charest et al. (172) showed that cells from a glioblastoma contained a $250 \mathrm{kbp}$ submicroscopic interstitial deletion causing fusion of the golgi associated PDZ and coiled-coil motif containing GOPC (also known as $F I G$ ) gene with ROS1. The GOPC-ROS1 transcript, which consists of the first seven exons of GOPC and the last nine exons of $R O S 1$, was in-frame and coded for a constitutively active GOPC-ROS1 chimeric protein that seems to be oncogenic $(172,173)$. At present, the GOPC-ROS1 chimera is considered to be a rare, but recurrent, fusion found in glioma, lung adenocarcinoma, cholangiocarcinoma, and high-grade serous ovarian carcinoma $(166,168,172,174$ 177). The chimeric GOPC-ROS 1 protein may be the target for kinase inhibitors $(160,166-169,177)$.

In 2013, a 41.5 Mbp interstitial deletion, del(6)(q22q25), was reported to fuse the first 10 exons of the ezrin $(E Z R)$ gene, which is transcribed from telomere to centromere and maps on 6q25.3, with exons 34-43 of the ROSI gene in lung adenocarcinomas from four female patients, three of whom had never been smokers (178). The EZR-ROSI gene coded for a chimeric protein with oncogenic activity. It contained the FERM domain of the EZR protein joined to the transmembrane and kinase domains of ROS1 (178). Additional studies confirmed the recurrence of EZR-ROSI in lung cancer and also that the finding was clinically important: the chimeric protein could be the target of kinase inhibitors with very good results $(160,161,167,169,179-184)$.

A chimera with the centrosomal protein 85 like (CEP85L) gene, which maps on 6q22.31, 1.0 Mbp distal to ROS1, and is transcribed from telomere to centromere, as the 5 '-end partner gene and ROS1 as the 3'-end partner gene has been reported in an angiosarcoma as well as a few glioblastomas (87, 166, 185-188). The chimeric CEP85L-ROS1 transcript was accompanied by deletion of the 5'-end of ROS1 suggesting that an interstitial $1.1 \mathrm{Mbp}$ submicroscopic deletion within band 6q22 caused the CEP85L-ROS1 chimera $(166,185)$. The $C E P 85 L-R O S 1$ transcript codes for a chimeric protein with oncogenic activity. The protein can be targeted with kinase inhibitors $(87,166,185-188)$.

Recently, three novel in-frame ROSI chimeric transcripts were detected $(161,164)$ using high throughput technology, probably corresponding to microdeletions between ROS1 (as the 3 '-end partner gene) and 5'-end partner genes $(161,164)$. In the first chimeric transcript, found in a melanoma of the skin, the SFT2 domain containing 1 (SFT2D1) gene was fused to ROSI (161). In the second transcript, found in a serous carcinoma of the ovary, an invasive ductal breast carcinoma, and in a carcinoma of unknown origin, the protein tyrosine phosphatase receptor type $\mathrm{K}$ (PTPRK) gene was fused to ROS1 (161). In the third transcript, found in a leiomyosarcoma, the mannosidase alpha class $1 \mathrm{~A}$ member 1 (MAN1A1) gene was fused with ROS1 (164). In vitro assays showed that the MAN1A1-ROS1 protein had strong transformation potential and that the kinase inhibitor crizotinib inhibited growth of MAN1A1-ROS1 transformed cells in a dose-dependent manner (164).

The SFT2D1, PTPRK, and MANIAl genes are distal to ROS1 and map on 6q27, 6q22.33, and 6q22.31, respectively. They are transcribed from telomere to centromere. Thus, a $49 \mathrm{Mbp}$ deletion is predicted to have caused the SFT2D1ROS1, an $11 \mathrm{Mbp}$ deletion the PTPRK-ROS1, whereas a 2 Mbp deletion probably resulted in the MAN1Al-ROS1 chimera.

The MYB proto-oncogene ( $M Y B$ is also known as $c-M Y B$ ) gene codes for a transcription regulator with three helix-turnhelix (HTH) DNA-binding domains, maps on 6q23.3, and is transcribed from centromere to telomere $(189,190)$. The gene and its paralogues $M Y B L 1$ (also known as $A-M Y B$, on 8q13.1) and MYBL2 (also known as $B-M Y B$, on 20q13.12) compose the MYB family of transcription factors which play important roles in cell growth, differentiation, and apoptosis (191-193). MYB regulates hematopoiesis, is crucial for colon development in murine animals, and is required for the proliferation of neural progenitor cells and maintenance of the neural stem cell niche $(189,193-196)$. Because $M Y B$ is involved in many malignancies such as leukemias and solid cancers of breast, colon, and brain, it has been considered as an attractive target for anti-tumor therapy $(193,197,198)$.

The QKI, KH domain containing RNA binding $(Q K I)$ gene, which codes for a protein that regulates pre-mRNA splicing, export of mRNAs from the nucleus, protein translation, and mRNA stability, maps on $6 \mathrm{q} 26$ and is transcribed from centromere to telomere (199-201). In 2014, Roth et al. (202) used high-resolution SNP array methodology to detect, in a pediatric ganglioglioma, a 30 Mbp deletion in 6q23.3-26 with the proximal breakpoint in the last intron of $M Y B$ and the distal one within the $Q K I$ gene. They proposed that the result of this deletion would be a $M Y B-Q K I$ fusion gene, a chimera that had previously been reported in a pediatric low-grade glioma (203). The $M Y B$ $Q K I$ fusion gene was subsequently found to characterize angiocentric gliomas (204-207). Interstitial deletion as a mechanism for the generation of the MYB-QKI fusion was reported in two of the studies (204-207). 


\section{Chromosome 7}

The B-Raf proto-oncogene, serine/threonine kinase $(B R A F)$ gene maps to $7 \mathrm{q} 34$ and transcribes from telomere to centromere (208-210). It codes for a member of the RAF family of serine/threonine protein kinases which is involved in regulating the MAP kinase/ERK signaling pathway and affects cell division, differentiation, and secretion (211-214).

Mutations in BRAF, most commonly the V600E mutation, have been found in many malignancies such as melanoma, colorectal cancer, thyroid carcinoma, non-small cell lung carcinoma, hairy cell leukemia, non-Hodgkin lymphoma, and adenocarcinoma of lung (214-216). The mutations play a fundamental role in cancer development. They constitutively activate $B R A F$ resulting in an over-performing RAF-MEKERK signaling cascade, promotion of cell proliferation and survival, and inhibition of apoptosis (214-216). The identification and characterization of pathogenic $B R A F$ mutations have led to the development of BRAF kinase inhibitors used to treat patients whose cancers carry this particular genetic abnormality $(214,215,217,218)$.

$B R A F$ chimeras have also been reported (12). In Mitelman's Database of Chromosome Aberrations and Gene Fusions in Cancer (updated October 15, 2020), 95 BRAF chimeras were registered with 30 of them involving a partner gene in $7 \mathrm{q}$.

Using aCGH, Cin et al. (219) found in three pilocytic astrocytomas a $2.5 \mathrm{Mbp}$ interstitial deletion in chromosome band 7q34. The deletion led to in-frame fusion of the currently uncharacterized gene with the name "family with sequence similarity 131-member B" (FAM131B) with BRAF. The chimeric FAM131B-BRAF protein was a constitutively active kinase with MEK phosphorylation potential and transforming activity in vitro (219). Subsequent studies confirmed the existence of a submicroscopic interstitial deletion in $7 \mathrm{q} 34$ and the recurrent generation of a FAM131B$B R A F$ chimeric gene in pilocytic astrocytomas $(202,206$, 220, 221).

\section{Chromosome 8}

The gene with the name "hes related family bHLH transcription factor with YRPW motif 1" (HEYl) maps on $8 \mathrm{q} 21.13$, is transcribed from telomere to centromere, and codes for a nuclear protein belonging to the hairy and enhancer of split-related (HESR) family of basic helix-loophelix (bHLH)-type transcriptional repressors (222-225). The nuclear receptor coactivator 2 (NCOA2) gene maps on $8 \mathrm{q} 13.3$, is also transcribed from telomere to centromere, and codes for a transcriptional coactivator of nuclear hormone receptors (226-229). A HEY1-NCOA2 fusion gene has been reported to be pathognomonic for mesenchymal chondrosarcoma (230-236). SNP array analyses of a few such chondrosarcomas indicated an interstitial deletion as the cause of the HEY1-NCOA2 chimeric gene $(221,231)$.

The pleomorphic adenoma gene 1 (PLAG1) maps to $8 \mathrm{q} 12.1$, is transcribed from telomere to centromere, and codes for a zinc finger transcription factor (237-240). PLAG1 spans $50 \mathrm{kbp}$ and contains 5 exons, the first 3 of which are untranslated (NCBI reference: NM_002655.3) (237, 241). PLAG1 was initially found to be rearranged in pleomorphic adenomas carrying a $\mathrm{t}(3 ; 8)(\mathrm{p} 22 ; \mathrm{q} 12)$ translocation which led to its fusion as a 3 '-end partner with the catenin beta 1 (CTNNB1) gene from 3p22.1 (237). Subsequently, various PLAG1-fusion genes were found in pleomorphic adenomas of the salivary glands, lipoblastomas, as well as other tumors (40-42, 242-246). In PLAG1 chimeras, the two fusion partner genes exchange their promoters and the 5 '-end untranslated exons. Consequently, the expression of PLAG1 is controlled and regulated by the fusion partner gene promoter. The PLAG1 gene is either overexpressed or activated which results in deregulation of its targeted genes and leading thus to tumor development $(240,247-251)$.

The hyaluronan synthase 2 (HAS2) gene maps on 8q24.13, is transcribed from telomere to centromere, and codes for the isoform 2 of hyaluronan synthase (252-256). HAS2 spans 29 $\mathrm{kb}$ and has 4 exons, the first of which is untranslated (NCBI reference: NM_005328.3). In 2000, a recurrent HAS2PLAG1 fusion gene was detected in three lipoblastomas, two of which had $\operatorname{del}(8)(q 12 q 24)$ and the third a ring chromosome 8 (244). The genomic breakpoints were in introns 1 of both HAS2 and PLAG1, and in the chimeric HAS2-PLAG1 transcripts, the untranslated exon 1 of HAS2 fused to either exon 2 or exon 3 of PLAG1 (244). Thus, the HAS2-PLAG1 fusion gene was the result of a $65.5 \mathrm{Mbp}$ interstitial $\operatorname{del}(8)(q 12 q 24)$ deletion. Subsequent reports on lipobastomas confirmed that the HAS2-PLAG1 fusion resulted from a del(8)(q12q24) (257-259).

The transcriptional repressor GATA binding 1 (TRPS1) gene maps on $8 \mathrm{q} 23.3$, is transcribed from telomere to centromere, and codes for a transcription factor that represses GATA-regulated genes and binds to a dynein lightchain protein (260). TRPS1 spans $260 \mathrm{kbp}$ and has seven exons, the first of which is untranslated (NCBI reference: NM_014112.5). Chimeric TRPS1-PLAG1 transcripts in which exon 1 of TRPS1 was fused to exon 2 or exon 3 of PLAG1, were reported in soft tissue myoepithelial tumor, uterine myxoid leiomyosarcoma, and chondroid syringoma (40-42). G-banding analysis of the chondroid syringoma revealed an interstial deletion, del(8)(q12q23) (Figure 2A). aCGH examination confirmed the deletion and showed that it started in intron 1 of PLAG1 and ended in exon 1 of TRPS1 (Figure 2B). RT-PCR (Figure 2C) and Sanger sequencing (Figure 2D) confirmed the presence of the TRPS1-PLAG1 fusion transcripts. FISH analysis on metaphase spreads showed that the TRPS1-PLAG1 fusion 
gene was on the $\operatorname{del}(8)(q 12 q 23)$ chromosome (Figure $2 \mathrm{E})$. Thus, both the aCGH and karyotyping data indicated that a TRPS1-PLAG1 fusion gene had been formed as the result of a deletion (42).

The $\mathrm{N}$-myc downstream regulated 1 gene (NDRG1) maps to $8 \mathrm{q} 24.22$, is transcribed from telomere to centromere and codes for a cytoplasmic protein involved in stress and hormonal responses, cell growth, and differentiation (261264). The NDRG1 gene spans $60 \mathrm{kbp}$ and has sixteen exons of which the first is untranslated (NCBI reference: NM_006096.4). A chimeric NDRG1-PLAG1 transcript in which exon 1 of NDRG1 was fused to exon 3 of PLAG1 was found in a chondroid syringoma (42). FISH analysis showed that the NDRG1-PLAG1 chimeric gene was on a ring chromosome 8. No reciprocal PLAG1-NDRGl chimeric gene was seen. The data indicated that an interstitial deletion had caused the NDRG1-PLAG1 chimera (42).

\section{Chromosome 9}

A fusion of the SET nuclear proto-oncogene (SET) with the nucleoporin 214 (NUP214) gene, also known as CAN, was discovered by von Linden et al. in an acute undifferentiated leukemia with normal karyotype. The discovery was made while they were looking for the DEK-NUP214 (alias DEK$C A N)$ fusion gene generated by $\mathrm{t}(6 ; 9)(\mathrm{p} 22 ; \mathrm{q} 34)$ in acute myeloid leukemias (265-267).

SET and NUP214 map on 9q34.11 and 9q34.13, respectively, and are both transcribed from centromere to telomere. SET codes for a nuclear protein which inhibits both histone acetyltransferase and demethylation of DNA (268, 269), whereas NUP214 codes for a nuclear envelop protein which is a subunit of the nuclear pore complex (270). The SET-NUP214 protein is found within the nucleus. It causes disturbed intracellular localization of the chromosomal maintenance 1 (CRM1) protein that facilitates transport of RNA and protein across the nuclear membrane into the cytoplasm (271). As a consequence, disruption of the nuclear export system occurs. Recruitment of the SET-NUP214 protein onto $H O X$ gene clusters leads to aberrant expression of $H O X$ genes in leukemic cells $(271,272)$. Expression of SET-NUP214 in transgenic mice was shown to block hematopoietic differentiation (273).

In 2006, Rosati et al. reported that a $2.5 \mathrm{Mbp}$ deletion generated SET-NUP214 fusion in an AML-patient (274). Subsequent studies confirmed that the submicroscopic deletion did indeed lead to SET-CAN chimeras in leukemias (274-281).

The SET-NUP214 chimera has been detected in AML as well as in undifferentiated acute leukemia (AUL) and B- and T-differentiated lymphoblastic leukemias (B-ALL and TALL). Its overall frequency in T-ALL is $3-8 \%(275,277$, 282). SET-NUP 214 is rare in pediatric T-ALL but was found in as many as $13 \%$ of adult T-ALLs $(60,282)$. In a recent study of 24 patients whose leukemic cells carried a SETNUP214 and who had undergone allogeneic hematopoietic stem cell transplantation, those who expressed SET-NUP214 after transplantation fared badly (283).

\section{Chromosome 10}

Vesicle transport through interaction with t-SNAREs 1A (VTI1A) and transcription factor 7 like 2 (TCF7L2) are neighboring genes in 10q25.2-25.3, separated by $130 \mathrm{kbp}$. Both are transcribed from centromere to telomere (284). The VTIIA gene codes for a soluble N-ethylmaleimide-sensitive fusion protein-attachment protein receptor that is active in intracellular trafficking $(285,286)$. The TCF $7 L 2$ gene codes for a high mobility group (HMG) box-containing transcription factor that plays a key role in the Wnt signaling pathway $(287,288)$. Although several TCF7L2 tissue specific splice variants have been found, all of them code for a protein which has an N-terminal beta-catenin (CTNNB1)binding domain and a HMG-box region (287-289).

Genomic sequencing of colorectal adenocarcinomas identified a $540 \mathrm{kbp}$ deletion starting in intron 2 of the VTIIA gene and ending in intron 3 of the TCF7L2 gene, thus generating a VTI1A-TCF7L2 chimera which is in-frame transcribed and translated to a chimeric protein lacking the CTNNB1-binding domain of TCF7L2 (284). In the first study, the chimeric VTI1A-TCF7L2 gene was present in $3 \%$ of the examined colorectal carcinomas (284). Later, Nome et al. (290) detected the VTIIA-TCF7L2 fusion transcript in 42 $\%$ of colorectal cancers but also in $28 \%$ of normal colonic mucosa samples as well as in $25 \%$ of normal tissue samples taken from various other anatomical sites. They also detected seven different splice variants of the VTI1A-TCF7L2 transcript (290). These data indicate that VTIIA-TCF7L2 is not specific for cancer nor for cells emanating from the large bowel. Nevertheless, functional studies of the VTI1A-TCF4 chimeric protein have shown that it acts as a dominant negative regulator of the Wnt signaling pathway, and that its transcription is activated by CDX2 (291). It is possible that it plays a pathogenetic role in cancer in spite of its lack of specificity.

\section{Chromosome 11}

The histone-lysine N-methyltransferase 2A gene (KMT2A, also known as $M L L$ ) maps to $11 \mathrm{q} 23$ and is transcribed from centromere to telomere. It encodes a transcriptional coactivator with multiple functional motifs and domains, among them a menin-binding motif at the amino-terminus, DNA binding AT hooks, a cysteine rich CXXC domain, plant homeodomain finger motifs, a bromodomain, a transactivation domain, and a SET domain at the carboxyl-terminus responsible for histone 
H3 lysine 4 (H3K4) methyltransferase activity (292-297). $K M T 2 A$ is known to recombine with more than 100 different partners in hematologic malignances and solid tumors with most of the fusions coding for chimeric proteins (12). All KMT2A-chimeric proteins retain the menin-binding motif, the DNA binding AT hooks, and the CXXC domain indicating that they are essential for the transformation potential of the fusion proteins $(282,298-300)$.

Fusions of KMT2A with three genes - Rho guanine nucleotide exchange factor 12 (ARHGEF12), Casitas Blineage lymphoma proto-oncogene $(C B L)$, and decapping enzyme scavenger $(D C P S)$ - were found to result from interstitial deletions in various hematologic malignancies (Table I) (147, 282, 298-305).

KMT2A-ARHGEF 12 fusion is brought about by a $2 \mathrm{Mbp}$ deletion stretching from the major breakpoint cluster region of $K M T 2 A$, which spans from exon 7 to exon 13 , to intron 11 or 13 of ARHGEF12 (Figure 3) (299-301, 304, 305). The result is an in-frame KMT2A-ARHGEF 12 chimeric transcript that gives rise to a protein composed of the KMT2A aminoterminus and the ARHGEF12 carboxyl-terminus (299-301, $304,305)$. So far, seven cases with KMT2A-ARHGEF 12 fusion have been reported: three AMLs, three B-ALLs, and one high-grade B-cell lymphoma (147, 299-305). Figure 3 presents, in brief, our results on identification of a KMT2A$A R H G E F 12$ fusion gene generated by a therapy induced interstitial deletion in subband 11q23.3 in a child treated for acute myeloid leukemia (301). aCGH detects a deletion which starts in the KMT2A gene and ends in the ARHGEF12 gene (Figure $3 \mathrm{~A}$ ). The deletion is also confirmed by FISH (Figure 3B). Finally, molecular methodologies (genomic PCR and Sanger sequencing of the PCR amplified fragments) show that an intronic sequence of $K M T 2 A$ fuses to an intronic sequence of ARHGEF 12, generating a chimeric KMT2AARHGEF 12 gene (Figure 3C).

A $K M T 2 A-C B L$ fusion is generated by an $800 \mathrm{kbp}$ deletion starting within $K M T 2 A$ and ending in $C B L$ gene $(282,298$ $300)$. It gives rise to an in-frame $K M T 2 A-C B L$ chimeric transcript that translates into a chimeric protein. Up to now, $K M T 2 A-C B L$ fusion has been described in two AML and one T-Lineage ALL (282, 298-300).

Mayer et al. (306) described an AML patient with a $\operatorname{del}(11)(q 23)$ in the diagnostic karyotype. Detailed investigation showed that the leukemic cells carried a 7.8 Mbp interstitial deletion which fused a genomic sequence from intron 8 of $K M T 2 A$ with an intergenic sequence $7.2 \mathrm{kbp}$ upstream of the DCPS gene. DCPS maps on $11 \mathrm{q} 24.2,10 \mathrm{kbp}$ distal to TIRAP, and is transcribed, as is $K M T 2 A$, from centromere to telomere (306). At the transcription level, the deletion results in in-frame fusion of exon 8 of KMT2A with exon 2 of the DCPS gene (306).

The forkhead box R1 (FOXRl) gene maps to 11q23.3 (chr11:118,971,761-119,018,638), is transcribed from centromere to telomere, and codes for a member of the forkhead box (FOX) family of transcription factors which are expressed in the testis, predominantly in spermatogonia and meiotic spermatocytes $(307,308)$. Santo et al. (309) identified interstitial microdeletions activating the FOXR1 gene in three neuroblastomas. In two of them, a $500 \mathrm{kbp}$ deletion between intron 1 of $K M T 2 A$ upstream of the FOXRl gene resulted in a KMT2A-FOXRl chimeric transcript in which the entire coding region of $F O X R 1$ was fused to exon 1 of KMT2A. In the third neuroblastoma, a 1.9 Mbp deletion within 11q23.3, starting within the platelet activating factor acetylhydrolase 1 b catalytic subunit 2 (PAFAH1B2) and ending just upstream of FOXRl, resulted in two PAFAHIB-FOXRl chimeric transcripts in which the entire coding region of $F O X R I$ was fused to exon 2 of PAFAHIB. Thus, both KMT2A-FOXR1 and PAFAH1B-FOXR1 resulted in FOXR1 expression (309).

\section{Chromosome 19}

In 2014, a $400 \mathrm{kbp}$ submicroscopic deletion in 19p13.12 was found to fuse the DnaJ heat shock protein family (Hsp40) member B1 (DNAJB1) gene with the protein kinase cAMPactivated catalytic subunit alpha (PRKACA) gene in all fifteen examined cases of fibrolamellar hepatocellular carcinoma, a rare liver cancer (310). Both DNAJBI and PRKACA are transcribed from centromere to telomere. Although the breakpoints were different in the examined cases, each deletion started either in intron 1 or exon 2 of $D N A J B 1$ and ended in intron 1 of PRKACA. The resulting DNAJB1$P R K A C A$ chimeric transcript thus comprised the first exon of DNAJB1 and exons 2-10 of PRKACA (310). The correlation between DNAJB1-PRKACA fusion gene formation and fibrolamellar hepatocellular carcinoma was quickly confirmed by other groups (311-316). Recently, the same fusion gene was reported to be recurrent also in intraductal oncocytic papillary neoplasms of the pancreas and bile ducts, cystic precursors to invasive carcinoma $(317,318)$.

The DNAJB1 gene codes for a member of the heat shock protein 40 family (HSP40) which interact with HSP70s and are involved in numerous cellular processes such as refolding, interaction, and transport of proteins $(319,320)$. PRKACA codes for one of the catalytic subunits of protein kinase A $(321,322)$. The DNAJB1-PRKACA gene codes for a chimeric protein kinase with oncogenic potential $(310,315$, $323,324)$. Both the first exon of $D N A J B 1$ and the kinase domain of PRKACA were required for tumorigenesis (324).

\section{Chromosome 21}

In 2005, Tomlins et al. (325) reported a recurrent fusion transcript of transmembrane serine protease 2 (TMPRSS2) with the E26 transformation-specific (ETS) related gene $(E R G)$, resulting in strong overexpression of $E R G$, in 

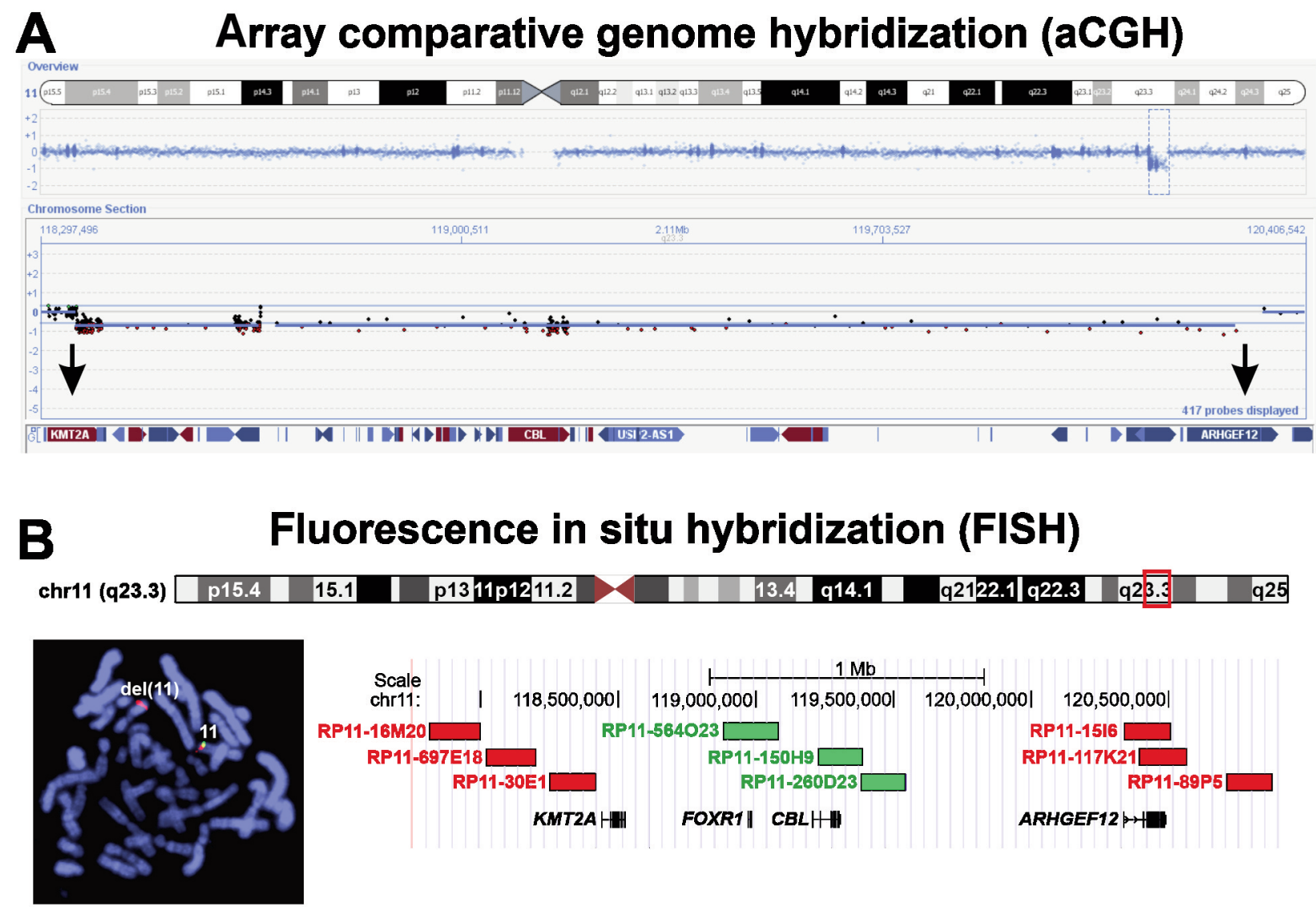

C

M 12

Molecular methologies

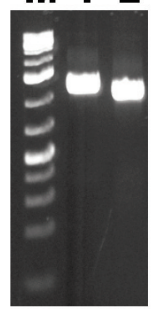

Genomic PCR
$K M T 2 A$ intron 9$\rfloor A R H G E F 12$ intron 13

CA GAGGAAGTAAT TC TT TACCACT G G T T T GAAT TT T T

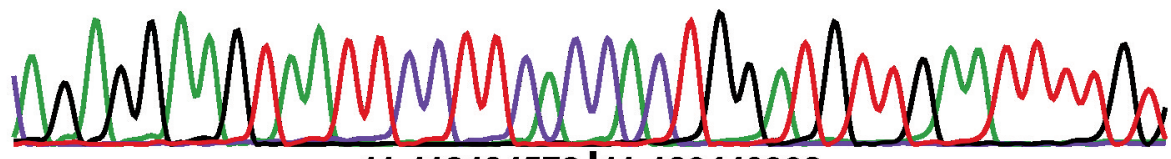

11:118484572|11:120440908

\section{Sanger sequencing}

Figure 3. Identification of a KMT2A-ARHGEF12 fusion gene generated by an interstitial deletion in subband 11q23.3. (A) Array comparative genome hybridization detects a deletion which starts in the KMT2A gene and ends in the ARHGEF12 gene. (B) Fluorescence in situ hybridization confirms the deletion between the KMT2A and ARHGEF12 genes. The green and red probes hybridized on the normal chromosome 11. Only the red probes hybridized on the del(11) indicating the deleted area (green signals missing). (C) Examinations using molecular methodologies (genomic PCR and Sanger sequencing of the PCR amplified fragments) show that an intronic sequence of KMT2A fuses to an intronic sequence of ARHGEF12, generating a chimeric KMT2A-ARHGEF12 gene. Data and figure are from reference 305.

prostate cancer. The TMPRSS2-ERG fusion transcript was quickly confirmed by other groups and was found to be present in at least $40 \%$ of prostate cancers (see below) and $20 \%$ of high-grade prostatic intraepithelial neoplasia (326-
331). The TPPRSS2 gene maps on 21q22.3, is transcribed from telomere to centromere, and codes for a type II transmembrane serine protease (332-334) which in prostate cancer is regulated by androgen $(335,336)$. The ERG gene 
maps on 21q22.2, 3.1 Mbp centromeric (proximal) to TMPRSS2. It is transcribed from telomere to centromere and codes for a member of the ETS family of transcription factors (337-339).

FISH and aCGH analyses show that the TMPRSS2-ERG fusion gene is generated by an approximately 3.0 Mbp interstitial deletion which starts in $E R G$ and ends in TMPRSS2, by translocation between the two chromosomes 21 or by microdeletion and concurrent translocation $(326,327$, $329-331,340-344)$. Roughly $40 \%$ to $60 \%$ of TMPRSS2-ERG fusion genes in patients with prostate cancer are generated by deletions $(345,346)$. Furthermore, prostate cancer patients whose tumor cells have a TMPRSS2-ERG fusion stemming from deletion, seem to have worse prognosis than those with a fusion resulting from translocation $(346,347)$. The $3 \mathrm{Mbp}$ region between ERG and TMPRSS 2 contains many genes which are involved in cancer and may function as tumor suppressor genes. The fact that the interstitial deletion which generates the TMPRSS2-ERG fusion gene, simultaneously results in haploinsufficiency for these genes, may explain the clinical difference. In a murine model, Linn et al. (348) showed that only mice lacking the interstitial region developed prostate adenocarcinoma marked by poor differentiation and epithelial-to-mesenchymal transition.

\section{Chromosome $\mathrm{X} / \mathrm{Y}$}

The genes cytokine receptor like factor 2 (CRLF2, also known as TSLPR) and $\mathrm{P} 2 \mathrm{Y}$ receptor family member 8 (P2RY8) map to the pseudoautosomal regions Xp22.33 and Yp11.2, are transcribed from centromere to telomere, and are separated by a $250 \mathrm{kbp}$ genomic region (349-353). CRLF2 codes for a receptor for thymic stromal lymphoprotein (TSLP) (349-352). CRLF2 together with interleukin 7 receptor (IL7R) and TSLP form the TSLPR complex which is capable of activating multiple signaling transduction pathways, among them the JAK/STAT pathway and the PI-3 kinase pathway (354-356).

$P 2 R Y 8$ codes for a member of the family of G-protein coupled receptors (357-359). The P2RY8 protein together with its ligand, S-geranylgeranyl-L-glutathione, and the enzyme gamma-glutamyltransferase-5, which metabolizes Sgeranylgeranyl-L-glutathione to a form that does not activate the P2RY8 receptor, promote confinement of $\mathrm{B}$-cells in germinal centers (357-359).

In 2009, two groups reported that in B-progenitor ALL a $300 \mathrm{kbp}$ interstitial deletion within the pseudoautosomal region Xp22.33/Yp11.2 juxtaposed the first, noncoding exon of $P 2 R Y 8$ with the coding region of $C R L F 2$ resulting in overexpression of $C R L F 2(360,361)$. The P2RY8-CRLF2 fusion was found in 5-7\% of patients with B-progenitor ALL but in more than $50 \%$ of B-ALL patients with Down syndrome (360-365). The P2RY8-CRLF2 fusion could be both an early and a clearly secondary genomic event in BALL development, making its role in leukemogenesis all the more intriguing $(363,366,367)$.

\section{Conclusion}

Although it may seem more likely that fusion genes or activated oncogenes are mainly caused by balanced genomic rearrangements, and although the early history of fusion gene detection in cancer apparently corroborated this view, we show here that interstitial chromosomal deletions are not an uncommon mechanism for the formation of similar fusion genes. Most of these deletions are below the detection level of chromosome banding methodologies and, hence, were detected using other techniques, including aCGH and high throughput sequencing. The detected interstitial deletions/fusion genes are not restricted to one or only a few chromosomes or a single type of cancer; instead, they have been found across almost the entire genome and in various neoplasias. Their detection has improved significantly our understanding of tumorigenesis and leukemogenesis and they are increasingly used for diagnosis and classification of neoplasms, prognostication, and as targets for molecular therapy. As more neoplasms are being analyzed, especially as high throughput sequencing is increasingly being relied on in laboratory diagnostic routines, even more such interstitial deletions/fusion genes are likely to be found, something that is going to have a significant impact both clinically and scientifically. The challenge in this context, however, is to apply proper verification/falsification measures to all new discoveries that will be made so that the field does not become swamped by data of questionable significance.

\section{Conflicts of Interest}

The Authors declare that they have no potential conflicts of interest with regards to this study.

\section{Authors' Contributions}

Both authors (IP and SH) wrote the manuscript.

\section{Acknowledgements}

This work was supported by grants from Radiumhospitalets Legater.

\section{References}

1 Rabbitts TH: Chromosomal translocations in human cancer. Nature 372(6502): 143-149, 1994. PMID: 7969446. DOI: $10.1038 / 372143 \mathrm{a} 0$

2 Rowley JD: The critical role of chromosome translocations in human leukemias. Annu Rev Genet 32: 495-519, 1998. PMID: 9928489. DOI: 10.1146/annurev.genet.32.1.495 
3 Mitelman F, Johansson B and Mertens F: The impact of translocations and gene fusions on cancer causation. Nat Rev Cancer 7(4): 233-245, 2007. PMID: 17361217. DOI: $10.1038 /$ nrc2091

4 Edwards PA: Fusion genes and chromosome translocations in the common epithelial cancers. J Pathol 220(2): 244-254, 2010. PMID: 19921709. DOI: $10.1002 /$ path.2632

5 Zheng J: Oncogenic chromosomal translocations and human cancer (review). Oncol Rep 30(5): 2011-2019, 2013. PMID: 23970180. DOI: 10.3892/or.2013.2677

6 Reshmi SC, Harvey RC, Roberts KG, Stonerock E, Smith A, Jenkins H, Chen IM, Valentine M, Liu Y, Li Y, Shao Y, Easton J, Payne-Turner D, Gu Z, Tran TH, Nguyen JV, Devidas M, Dai Y, Heerema NA, Carroll AJ 3rd, Raetz EA, Borowitz MJ, Wood BL, Angiolillo AL, Burke MJ, Salzer WL, Zweidler-McKay PA, Rabin KR, Carroll WL, Zhang J, Loh ML, Mullighan CG, Willman CL, Gastier-Foster JM and Hunger SP: Targetable kinase gene fusions in high-risk B-ALL: A study from the children's oncology group. Blood 129(25): 3352-3361, 2017. PMID: 28408464. DOI: 10.1182/blood-2016-12-758979

7 Xiao X, Garbutt CC, Hornicek F, Guo Z and Duan Z: Advances in chromosomal translocations and fusion genes in sarcomas and potential therapeutic applications. Cancer Treat Rev 63: 61-70, 2018. PMID: 29247978. DOI: 10.1016/j.ctrv.2017.12.001

8 Matsukawa $\mathrm{T}$ and Aplan PD: Clinical and molecular consequences of fusion genes in myeloid malignancies. Stem Cells 38(11): 1366-1374, 2020. PMID: 32745287. DOI: 10.1002/stem. 3263

9 Pederzoli F, Bandini M, Marandino L, Ali SM, Madison R, Chung J, Ross JS and Necchi A: Targetable gene fusions and aberrations in genitourinary oncology. Nat Rev Urol 17(11): 613-625, 2020. PMID: 33046892. DOI: 10.1038/s41585-020-00379-4

10 Mitelman F, Johansson B and Mertens F: Fusion genes and rearranged genes as a linear function of chromosome aberrations in cancer. Nat Genet 36(4): 331-334, 2004. PMID: 15054488. DOI: $10.1038 / \mathrm{ng} 1335$

11 Heim S and Mitelman F: Cancer cytogenetics: Chromosomal and molecular genetic abberations of tumor cells. Fourth edition edn. Wiley-Blackwell, 2015.

12 Mitelman F, Johansson B and Mertens F: Mitelman Database of Chromosome Aberrations and Gene Fusions in Cancer, 2021. Available at: https://mitelmandatabase.isb-cgc.org/[Last accessed on March 16, 2021]

13 Johansson B, Mertens F, Schyman T, Björk J, Mandahl N and Mitelman F: Most gene fusions in cancer are stochastic events. Genes Chromosomes Cancer 58(9): 607-611, 2019. PMID: 30807681. DOI: $10.1002 / \mathrm{gcc} .22745$

14 Gauwerky CE and Croce CM: Chromosomal translocations in leukaemia. Semin Cancer Biol 4(6): 333-340, 1993. PMID: 8142618.

15 Hunger SP and Cleary ML: Chimaeric oncoproteins resulting from chromosomal translocations in acute lymphoblastic leukaemia. Semin Cancer Biol 4(6): 387-399, 1993. PMID: 8142624.

16 Ladanyi M: The emerging molecular genetics of sarcoma translocations. Diagn Mol Pathol 4(3): 162-173, 1995. PMID: 7493135. DOI: 10.1097/00019606-199509000-00003

17 Brenner JC and Chinnaiyan AM: Translocations in epithelial cancers. Biochim Biophys Acta 1796(2): 201-215, 2009. PMID: 19406209. DOI: 10.1016/j.bbcan.2009.04.005
18 Nowell PC and Croce CM: Chromosomal approaches to oncogenes and oncogenesis. FASEB J 2(15): 3054-3060, 1988. PMID: 3056765. DOI: 10.1096/fasebj.2.15.3056765

19 Dong JT: Chromosomal deletions and tumor suppressor genes in prostate cancer. Cancer Metastasis Rev 20(3-4): 173-193, 2001. PMID: 12085961. DOI: 10.1023/a:1015575125780

20 Chen M, Yang Y, Liu Y and Chen C: The role of chromosome deletions in human cancers. Adv Exp Med Biol 1044: 135-148, 2018. PMID: 29956295. DOI: 10.1007/978-981-13-0593-1_9

21 Francke U and Kung F: Sporadic bilateral retinoblastoma and 13q- chromosomal deletion. Med Pediatr Oncol 2(4): 379-385, 1976. PMID: 1004381. DOI: 10.1002/mpo.2950020404

22 Knudson AG Jr, Meadows AT, Nichols WW and Hill R: Chromosomal deletion and retinoblastoma. N Engl J Med 295(20): 1120-1123, 1976. PMID: 980006. DOI: 10.1056/ NEJM197611112952007

23 Noel B, Quack B and Rethore MO: Partial deletions and trisomies of chromosome 13; Mapping of bands associated with particular malformations. Clin Genet 9(6): 593-602, 1976. PMID: 1277571. DOI: 10.1111/j.1399-0004.1976.tb01618.x

24 Benedict WF, Murphree AL, Banerjee A, Spina CA, Sparkes MC and Sparkes RS: Patient with 13 chromosome deletion: Evidence that the retinoblastoma gene is a recessive cancer gene. Science 219(4587): 973-975, 1983. PMID: 6336308. DOI: 10.1126/ science. 6336308

25 Dryja TP, Friend S and Weinberg RA: Genetic sequences that predispose to retinoblastoma and osteosarcoma. Symp Fundam Cancer Res 39: 115-119, 1986. PMID: 3480547.

26 Friend SH, Bernards R, Rogelj S, Weinberg RA, Rapaport JM, Albert DM and Dryja TP: A human DNA segment with properties of the gene that predisposes to retinoblastoma and osteosarcoma. Nature 323(6089): 643-646, 1986. PMID: 2877398. DOI: $10.1038 / 323643 \mathrm{a} 0$

27 Sherr CJ: Principles of tumor suppression. Cell 116(2): 235-246, 2004. PMID: 14744434. DOI: 10.1016/s0092-8674(03)01075-4

28 Kamb A, Gruis NA, Weaver-Feldhaus J, Liu Q, Harshman K, Tavtigian SV, Stockert E, Day RS 3rd, Johnson BE and Skolnick MH: A cell cycle regulator potentially involved in genesis of many tumor types. Science 264(5157): 436-440, 1994. PMID: 8153634. DOI: $10.1126 /$ science. 8153634

29 Nobori T, Miura K, Wu DJ, Lois A, Takabayashi K and Carson DA: Deletions of the cyclin-dependent kinase-4 inhibitor gene in multiple human cancers. Nature 368(6473): 753-756, 1994. PMID: 8152487. DOI: $10.1038 / 368753 \mathrm{a} 0$

30 Sasaki S, Kitagawa Y, Sekido Y, Minna JD, Kuwano H, Yokota $\mathrm{J}$ and Kohno T: Molecular processes of chromosome 9p21 deletions in human cancers. Oncogene 22(24): 3792-3798, 2003. PMID: 12802286. DOI: 10.1038/sj.onc.1206589

31 Kohno T and Yokota J: Molecular processes of chromosome 9p21 deletions causing inactivation of the p16 tumor suppressor gene in human cancer: Deduction from structural analysis of breakpoints for deletions. DNA Repair (Amst) 5(9-10): 1273-1281, 2006. PMID: 16931177. DOI: 10.1016/j.dnarep.2006.05.021

32 Fero ML, Randel E, Gurley KE, Roberts JM and Kemp CJ: The murine gene p27Kip1 is haplo-insufficient for tumour suppression. Nature 396(6707): 177-180, 1998. PMID: 9823898. DOI: $10.1038 / 24179$

33 Quon KC and Berns A: Haplo-insufficiency? Let me count the ways. Genes Dev 15(22): 2917-2921, 2001. PMID: 11711426. DOI: $10.1101 / \mathrm{gad} .949001$ 
34 Johnson AF, Nguyen HT and Veitia RA: Causes and effects of haploinsufficiency. Biol Rev Camb Philos Soc 94(5): 1774-1785, 2019. PMID: 31149781 . DOI: $10.1111 /$ brv.12527

35 Maher CA, Kumar-Sinha C, Cao X, Kalyana-Sundaram S, Han B, Jing X, Sam L, Barrette T, Palanisamy N and Chinnaiyan AM: Transcriptome sequencing to detect gene fusions in cancer. Nature 458(7234): 97-101, 2009. PMID: 19136943. DOI: 10.1038/nature07638

36 Kumar S, Razzaq SK, Vo AD, Gautam M and Li H: Identifying fusion transcripts using next generation sequencing. Wiley Interdiscip Rev RNA 7(6): 811-823, 2016. PMID: 27485475. DOI: $10.1002 /$ wrna.1382

37 McLeer-Florin A, Duruisseaux M, Pinsolle J, Dubourd S, Mondet J, Phillips Houlbracq M, Magnat N, Fauré J, Chatagnon A, de Fraipont F, Giaj Levra M, Toffart AC, Ferretti G, Hainaut P, Brambilla E, Moro-Sibilot D and Lantuejoul S: ALK fusion variants detection by targeted RNA-next generation sequencing and clinical responses to crizotinib in ALK-positive non-small cell lung cancer. Lung Cancer 116: 15-24, 2018. PMID: 29413046. DOI: 10.1016/j.lungcan.2017.12.004

38 Heyer EE, Deveson IW, Wooi D, Selinger CI, Lyons RJ, Hayes VM, O'Toole SA, Ballinger ML, Gill D, Thomas DM, Mercer TR and Blackburn J: Diagnosis of fusion genes using targeted RNA sequencing. Nat Commun 10(1): 1388, 2019. PMID: 30918253. DOI: 10.1038/s41467-019-09374-9

39 Avenarius MR, Miller CR, Arnold MA, Koo S, Roberts R, Hobby M, Grossman T, Moyer Y, Wilson RK, Mardis ER, Gastier-Foster JM and Pfau RB: Genetic characterization of pediatric sarcomas by targeted RNA sequencing. J Mol Diagn 22(10): 1238-1245, 2020. PMID: 32745614. DOI: 10.1016/j.jmoldx.2020.07.004

40 Arias-Stella JA 3rd, Benayed R, Oliva E, Young RH, Hoang LN, Lee CH, Jungbluth AA, Frosina D, Soslow RA, Antonescu CR, Ladanyi M and Chiang S: Novel PLAG1 gene rearrangement distinguishes a subset of uterine myxoid leiomyosarcoma from other uterine myxoid mesenchymal tumors. Am J Surg Pathol 43(3): 382-388, 2019. PMID: 30489320. DOI: 10.1097/PAS.0000000000001196

41 Zhu G, Benayed R, Ho C, Mullaney K, Sukhadia P, Rios K, Berry R, Rubin BP, Nafa K, Wang L, Klimstra DS, Ladanyi M and Hameed MR: Diagnosis of known sarcoma fusions and novel fusion partners by targeted RNA sequencing with identification of a recurrent ACTB-FOSB fusion in pseudomyogenic hemangioendothelioma. Mod Pathol 32(5): 609-620, 2019. PMID: 30459475. DOI: 10.1038/s41379-018$0175-7$

42 Panagopoulos I, Gorunova L, Andersen K, Lund-Iversen M, Lobmaier I, Micci F and Heim S: NDRG1-PLAG1 and TRPS1PLAG1 fusion genes in chondroid syringoma. Cancer Genomics Proteomics 17(3): 237-248, 2020. PMID: 32345665. DOI: 10.21873/cgp.20184

43 Akiva P, Toporik A, Edelheit S, Peretz Y, Diber A, Shemesh R, Novik A and Sorek R: Transcription-mediated gene fusion in the human genome. Genome Res 16(1): 30-36, 2006. PMID: 16344562. DOI: $10.1101 /$ gr.4137606

44 Parra G, Reymond A, Dabbouseh N, Dermitzakis ET, Castelo R, Thomson TM, Antonarakis SE and Guigó R: Tandem chimerism as a means to increase protein complexity in the human genome. Genome Res 16(1): 37-44, 2006. PMID: 16344564. DOI: $10.1101 /$ gr.4145906
45 Greger L, Su J, Rung J, Ferreira PG, Geuvadis consortium., Lappalainen T, Dermitzakis ET and Brazma A: Tandem RNA chimeras contribute to transcriptome diversity in human population and are associated with intronic genetic variants. PLoS One 9(8): e104567, 2014. PMID: 25133550. DOI: 10.1371/journal.pone.0104567

46 Ren G, Zhang Y, Mao X, Liu X, Mercer E, Marzec J, Ding D, Jiao Y, Qiu Q, Sun Y, Zhang B, Yeste-Velasco M, Chelala C, Berney D and Lu YJ: Transcription-mediated chimeric RNAs in prostate cancer: Time to revisit old hypothesis? OMICS 18(10): 615-624, 2014. PMID: 25188740. DOI: 10.1089/omi.2014.0042

47 Barresi V, Cosentini I, Scuderi C, Napoli S, Di Bella V, Spampinato $\mathrm{G}$ and Condorelli DF: Fusion transcripts of adjacent genes: New insights into the world of human complex transcripts in cancer. Int J Mol Sci 20(21):5252, 2019. PMID: 31652751. DOI: $10.3390 /$ ijms 20215252

48 Lu G, Wu J, Zhao G, Wang Z, Chen W and Mu S: Abundant and broad expression of transcription-induced chimeras and protein products in mammalian genomes. Biochem Biophys Res Commun 470(3): 759-765, 2016. PMID: 26718406. DOI: 10.1016/j.bbrc.2015.12.084

49 Prakash T, Sharma VK, Adati N, Ozawa R, Kumar N, Nishida Y, Fujikake T, Takeda T and Taylor TD: Expression of conjoined genes: Another mechanism for gene regulation in eukaryotes. PLoS One 5(10): e13284, 2010. PMID: 20967262. DOI: 10.1371/journal.pone.0013284

50 He Y, Yuan C, Chen L, Lei M, Zellmer L, Huang H and Liao DJ: Transcriptional-readthrough RNAs reflect the phenomenon of "A Gene Contains Gene(s)" or "Gene(s) within a Gene" in the Human Genome, and thus are not chimeric RNAs. Genes (Basel) 9(1):40, 2018. PMID: 29337901. DOI: 10.3390/genes9010040

51 Rickman DS, Pflueger D, Moss B, VanDoren VE, Chen CX, de la Taille A, Kuefer R, Tewari AK, Setlur SR, Demichelis F and Rubin MA: SLC45A3-ELK4 is a novel and frequent erythroblast transformation-specific fusion transcript in prostate cancer. Cancer Res 69(7): 2734-2738, 2009. PMID: 19293179. DOI: 10.1158/0008-5472.CAN-08-4926

52 Kumar-Sinha C, Kalyana-Sundaram S and Chinnaiyan AM: SLC45A3-ELK4 chimera in prostate cancer: Spotlight on cissplicing. Cancer Discov 2(7): 582-585, 2012. PMID: 22787087. DOI: $10.1158 / 2159-8290 . C D-12-0212$

53 Zhang Y, Gong M, Yuan H, Park HG, Frierson HF and Li H: Chimeric transcript generated by cis-splicing of adjacent genes regulates prostate cancer cell proliferation. Cancer Discov 2(7): 598-607, 2012. PMID: 22719019. DOI: 10.1158/2159-8290.CD12-0042

54 Vulprecht J, David A, Tibelius A, Castiel A, Konotop G, Liu F, Bestvater F, Raab MS, Zentgraf H, Izraeli S and Krämer A: STIL is required for centriole duplication in human cells. J Cell Sci 125(Pt 5): 1353-1362, 2012. PMID: 22349705. DOI: 10.1242 /jcs.104109

55 Hsu HL, Huang L, Tsan JT, Funk W, Wright WE, Hu JS, Kingston $\mathrm{RE}$ and Baer R: Preferred sequences for DNA recognition by the TAL1 helix-loop-helix proteins. Mol Cell Biol 14(2): 1256-1265, 1994. PMID: 8289805. DOI: $10.1128 / \mathrm{mcb} .14 .2 .1256$

56 Aplan PD, Lombardi DP, Ginsberg AM, Cossman J, Bertness VL and Kirsch IR: Disruption of the human SCL locus by "illegitimate" V-(D)-J recombinase activity. Science 250(4986): 1426-1429, 1990. PMID: 2255914. DOI: $10.1126 /$ science. 2255914 
57 Brown L, Cheng JT, Chen Q, Siciliano MJ, Crist W, Buchanan $\mathrm{G}$ and Baer R: Site-specific recombination of the tal-1 gene is a common occurrence in human T cell leukemia. EMBO J 9(10): 3343-3351, 1990. PMID: 2209547.

58 Chopra A, Soni S, Verma D, Kumar D, Dwivedi R, Vishwanathan A, Vishwakama G, Bakhshi S, Seth R, Gogia A, Kumar L and Kumar R: Prevalence of common fusion transcripts in acute lymphoblastic leukemia: A report of 304 cases. Asia Pac J Clin Oncol 11(4): 293-298, 2015. PMID: 26264145. DOI: 10.1111/ajco. 12400

59 D'Angiò M, Valsecchi MG, Testi AM, Conter V, Nunes V, Parasole R, Colombini A, Santoro N, Varotto S, Caniglia M, Silvestri D, Consarino C, Levati L, Magrin E, Locatelli F, Basso G, Foà R, Biondi A and Cazzaniga G: Clinical features and outcome of SIL/TAL1-positive T-cell acute lymphoblastic leukemia in children and adolescents: A 10-year experience of the AIEOP group. Haematologica 100(1): e10-e13, 2015. PMID: 25304610. DOI: 10.3324/haematol.2014.112151

60 Liu Y, Easton J, Shao Y, Maciaszek J, Wang Z, Wilkinson MR, McCastlain K, Edmonson M, Pounds SB, Shi L, Zhou X, Ma X, Sioson E, Li Y, Rusch M, Gupta P, Pei D, Cheng C, Smith MA, Auvil JG, Gerhard DS, Relling MV, Winick NJ, Carroll AJ, Heerema NA, Raetz E, Devidas M, Willman CL, Harvey RC, Carroll WL, Dunsmore KP, Winter SS, Wood BL, Sorrentino BP, Downing JR, Loh ML, Hunger SP, Zhang J and Mullighan CG: The genomic landscape of pediatric and young adult T-lineage acute lymphoblastic leukemia. Nat Genet 49(8): 1211-1218, 2017. PMID: 28671688. DOI: 10.1038/ng.3909

61 Bash RO, Crist WM, Shuster JJ, Link MP, Amylon M, Pullen J, Carroll AJ, Buchanan GR, Smith RG and Baer R: Clinical features and outcome of T-cell acute lymphoblastic leukemia in childhood with respect to alterations at the TAL1 locus: A Pediatric Oncology Group study. Blood 81(8): 2110-2117, 1993. PMID: 8471769.

62 Wang D, Zhu G, Wang N, Zhou X, Yang Y, Zhou S, Xiong J, He J, Jiang L, Li C, Xu D, Huang L and Zhou J: SIL-TAL1 rearrangement is related with poor outcome: A study from a Chinese institution. PLoS One 8(9): e73865, 2013. PMID: 24040098. DOI: 10.1371/journal.pone.0073865

63 Ballerini P, Landman-Parker J, Cayuela JM, Asnafi V, Labopin M, Gandemer V, Perel Y, Michel G, Leblanc T, Schmitt C, Fasola S, Hagemejier A, Sigaux F, Auclerc MF, Douay L, Leverger G and Baruchel A: Impact of genotype on survival of children with T-cell acute lymphoblastic leukemia treated according to the French protocol FRALLE-93: The effect of TLX3/HOX11L2 gene expression on outcome. Haematologica 93(11): 1658-1665, 2008. PMID: 18835836. DOI: 10.3324/haematol.13291

64 Mansur MB, Emerenciano M, Brewer L, Sant'Ana M, Mendonça N, Thuler LC, Koifman S and Pombo-de-Oliveira MS: SILTAL1 fusion gene negative impact in T-cell acute lymphoblastic leukemia outcome. Leuk Lymphoma 50(8): 1318-1325, 2009. PMID: 19562638. DOI: 10.1080/10428190903040014

65 Kelliher MA, Seldin DC and Leder P: Tal-1 induces T cell acute lymphoblastic leukemia accelerated by casein kinase IIalpha. EMBO J 15(19): 5160-5166, 1996. PMID: 8895560.

66 Tremblay M, Tremblay CS, Herblot S, Aplan PD, Hébert J, Perreault $\mathrm{C}$ and Hoang T: Modeling T-cell acute lymphoblastic leukemia induced by the SCL and LMO1 oncogenes. Genes Dev 24(11): 1093-1105, 2010. PMID: 20516195. DOI: 10.1101/ gad. 1897910
67 Wiesner T, He J, Yelensky R, Esteve-Puig R, Botton T, Yeh I, Lipson D, Otto G, Brennan K, Murali R, Garrido M, Miller VA, Ross JS, Berger MF, Sparatta A, Palmedo G, Cerroni L, Busam KJ, Kutzner H, Cronin MT, Stephens PJ and Bastian BC: Kinase fusions are frequent in spitz tumours and spitzoid melanomas. Nat Commun 5: 3116, 2014. PMID: 24445538. DOI: $10.1038 /$ ncomms 4116

68 Agaram NP, Zhang L, Sung YS, Chen CL, Chung CT, Antonescu CR and Fletcher CD: Recurrent NTRK1 gene fusions define a novel subset of locally aggressive lipofibromatosis-like neural tumors. Am J Surg Pathol 40(10): 1407-1416, 2016. PMID: 27259011. DOI: 10.1097/PAS.0000000000000675

69 Haller F, Knopf J, Ackermann A, Bieg M, Kleinheinz K, Schlesner M, Moskalev EA, Will R, Satir AA, Abdelmagid IE, Giedl J, Carbon R, Rompel O, Hartmann A, Wiemann S, Metzler $\mathrm{M}$ and Agaimy A: Paediatric and adult soft tissue sarcomas with NTRK1 gene fusions: A subset of spindle cell sarcomas unified by a prominent myopericytic/haemangiopericytic pattern. J Pathol 238(5): 700-710, 2016. PMID: 26863915. DOI: 10.1002/ path. 4701

70 Park DY, Choi C, Shin E, Lee JH, Kwon CH, Jo HJ, Kim HR, Kim HS, Oh N, Lee JS, Park OK, Park E, Park J, Shin JY, Kim JI, Seo JS, Park HD and Park J: NTRK1 fusions for the therapeutic intervention of Korean patients with colon cancer. Oncotarget 7(7): 8399-8412, 2016. PMID: 26716414. DOI: 10.18632/oncotarget.6724

71 Sartore-Bianchi A, Ardini E, Bosotti R, Amatu A, Valtorta E, Somaschini A, Raddrizzani L, Palmeri L, Banfi P, Bonazzina E, Misale S, Marrapese G, Leone A, Alzani R, Luo D, Hornby Z, Lim J, Veronese S, Vanzulli A, Bardelli A, Martignoni M, Davite C, Galvani A, Isacchi A and Siena S: Sensitivity to entrectinib associated with a novel LMNA-NTRK1 gene fusion in metastatic colorectal cancer. J Natl Cancer Inst 108(1): , 2015. PMID: 26563355. DOI: 10.1093/jnci/djv306

72 Wong V, Pavlick D, Brennan T, Yelensky R, Crawford J, Ross JS, Miller VA, Malicki D, Stephens PJ, Ali SM and Ahn H: Evaluation of a congenital infantile fibrosarcoma by comprehensive genomic profiling reveals an LMNA-NTRK1 gene fusion responsive to crizotinib. J Natl Cancer Inst 108(1): 2015. PMID: 26563356. DOI: 10.1093/jnci/djv307

73 Pavlick D, Schrock AB, Malicki D, Stephens PJ, Kuo DJ, Ahn $\mathrm{H}$, Turpin B, Allen JM, Rosenzweig M, Badizadegan K, Ross JS, Miller VA, Wong V and Ali SM: Identification of NTRK fusions in pediatric mesenchymal tumors. Pediatr Blood Cancer 64(8): , 2017. PMID: 28097808. DOI: 10.1002/pbc.26433

74 Chiang S, Cotzia P, Hyman DM, Drilon A, Tap WD, Zhang L, Hechtman JF, Frosina D, Jungbluth AA, Murali R, Park KJ, Soslow RA, Oliva E, Iafrate AJ, Benayed R, Ladanyi M and Antonescu CR: NTRK fusions define a novel uterine sarcoma subtype with features of fibrosarcoma. Am J Surg Pathol 42(6): 791-798, 2018. PMID: 29553955. DOI: 10.1097/PAS.00000 00000001055

75 Gao Q, Liang WW, Foltz SM, Mutharasu G, Jayasinghe RG, Cao S, Liao WW, Reynolds SM, Wyczalkowski MA, Yao L, Yu L, Sun SQ, Fusion Analysis Working Group., Cancer Genome Atlas Research Network., Chen K, Lazar AJ, Fields RC, Wendl MC, Van Tine BA, Vij R, Chen F, Nykter M, Shmulevich I and Ding L: Driver fusions and their implications in the development and treatment of human cancers. Cell Rep 23(1): 227-238.e3, 2018. PMID: 29617662. DOI: 10.1016/j.celrep.2018.03.050 
76 Pozdeyev N, Gay LM, Sokol ES, Hartmaier R, Deaver KE, Davis S, French JD, Borre PV, LaBarbera DV, Tan AC, Schweppe RE, Fishbein L, Ross JS, Haugen BR and Bowles DW: Genetic analysis of 779 advanced differentiated and anaplastic thyroid cancers. Clin Cancer Res 24(13): 3059-3068, 2018. PMID: 29615459. DOI: 10.1158/1078-0432.CCR-18-0373

77 Suurmeijer AJH, Dickson BC, Swanson D, Zhang L, Sung YS, Cotzia P, Fletcher CDM and Antonescu CR: A novel group of spindle cell tumors defined by S100 and CD34 co-expression shows recurrent fusions involving RAF1, BRAF, and NTRK1/2 genes. Genes Chromosomes Cancer 57(12): 611-621, 2018. PMID: 30276917. DOI: $10.1002 / \mathrm{gcc} .22671$

78 Wegert J, Vokuhl C, Collord G, Del Castillo Velasco-Herrera M, Farndon SJ, Guzzo C, Jorgensen M, Anderson J, Slater O, Duncan C, Bausenwein S, Streitenberger H, Ziegler B, Furtwängler R, Graf N, Stratton MR, Campbell PJ, Jones DT, Koelsche C, Pfister SM, Mifsud W, Sebire N, Sparber-Sauer M, Koscielniak E, Rosenwald A, Gessler M and Behjati S: Recurrent intragenic rearrangements of EGFR and BRAF in soft tissue tumors of infants. Nat Commun 9(1): 2378, 2018. PMID: 29915264. DOI: 10.1038/s41467-018-04650-6

79 Zhou N, Schäfer R, Li T, Fang M and Liu L: A primary undifferentiated pleomorphic sarcoma of the lumbosacral region harboring a LMNA-NTRK1 gene fusion with durable clinical response to crizotinib: A case report. BMC Cancer 18(1): 842, 2018. PMID: 30134855. DOI: 10.1186/s12885-018-4749-Z

80 Hsiao SJ, Zehir A, Sireci AN and Aisner DL: Detection of tumor NTRK gene fusions to identify patients who may benefit from tyrosine kinase (TRK) inhibitor therapy. J Mol Diagn 21(4): 553571, 2019. PMID: 31075511. DOI: 10.1016/j.jmoldx 2019.03.008

81 Doebele RC, Davis LE, Vaishnavi A, Le AT, Estrada-Bernal A, Keysar S, Jimeno A, Varella-Garcia M, Aisner DL, Li Y, Stephens PJ, Morosini D, Tuch BB, Fernandes M, Nanda N and Low JA: An oncogenic NTRK fusion in a patient with soft-tissue sarcoma with response to the tropomyosin-related kinase inhibitor LOXO-101. Cancer Discov 5(10): 1049-1057, 2015. PMID: 26216294. DOI: 10.1158/2159-8290.CD-15-0443

82 Russo M, Misale S, Wei G, Siravegna G, Crisafulli G, Lazzari L, Corti G, Rospo G, Novara L, Mussolin B, Bartolini A, Cam N, Patel R, Yan S, Shoemaker R, Wild R, Di Nicolantonio F, Bianchi AS, Li G, Siena S and Bardelli A: Acquired resistance to the TRK inhibitor entrectinib in colorectal cancer. Cancer Discov 6(1): 36-44, 2016. PMID: 26546295. DOI: 10.1158/21598290.CD-15-0940

83 Bhangoo MS and Sigal D: TRK Inhibitors: Clinical development of larotrectinib. Curr Oncol Rep 21(2): 14, 2019. PMID: 30715603. DOI: 10.1007/s11912-019-0761-y

84 Dupuis M, Shen Y, Curcio C, Meis JM, Wang WL, Amini B, Rhines L, Reuther J, Roy A, Fisher KE, Conley AP and Andrew Livingston J: Successful treatment of lipofibromatosis-like neural tumor of the lumbar spine with an NTRK-fusion inhibitor. Clin Sarcoma Res 10: 14, 2020. PMID: 32782782. DOI: 10.1186/s13569-020-00136-6

85 Walker A: Neurotrophic tyrosine kinase inhibitors: A review of implications for patients, clinicians and healthcare services. J Oncol Pharm Pract 26(8): 2015-2019, 2020. PMID: 32957860. DOI: $10.1177 / 1078155220959428$

86 Frattini V, Trifonov V, Chan JM, Castano A, Lia M, Abate F, Keir ST, Ji AX, Zoppoli P, Niola F, Danussi C, Dolgalev I, Porrati P,
Pellegatta S, Heguy A, Gupta G, Pisapia DJ, Canoll P, Bruce JN, McLendon RE, Yan H, Aldape K, Finocchiaro G, Mikkelsen T, Privé GG, Bigner DD, Lasorella A, Rabadan R and Iavarone A: The integrated landscape of driver genomic alterations in glioblastoma. Nat Genet 45(10): 1141-1149, 2013. PMID: 23917401. DOI: 10.1038/ng.2734

87 Shah N, Lankerovich M, Lee H, Yoon JG, Schroeder B and Foltz G: Exploration of the gene fusion landscape of glioblastoma using transcriptome sequencing and copy number data. BMC Genomics 14: 818, 2013. PMID: 24261984. DOI: 10.1186/14712164-14-818

88 Kim J, Lee Y, Cho HJ, Lee YE, An J, Cho GH, Ko YH, Joo KM and Nam DH: NTRK1 fusion in glioblastoma multiforme. PLoS One 9(3): e91940, 2014. PMID: 24647444. DOI: 10.1371/journal.pone.0091940

89 Sigal DS, Bhangoo MS, Hermel JA, Pavlick DC, Frampton G, Miller VA, Ross JS and Ali SM: Comprehensive genomic profiling identifies novel NTRK fusions in neuroendocrine tumors. Oncotarget 9(88): 35809-35812, 2018. PMID: 30533196. DOI: $10.18632 /$ oncotarget.26260

90 Cook PJ, Thomas R, Kannan R, de Leon ES, Drilon A, Rosenblum MK, Scaltriti M, Benezra R and Ventura A: Somatic chromosomal engineering identifies BCAN-NTRK1 as a potent glioma driver and therapeutic target. Nat Commun 8: 15987, 2017. PMID: 28695888. DOI: $10.1038 /$ ncomms 15987

91 Burki TK: Larotrectinib in TRK fusion-positive cancers. Lancet Oncol 19(4): e187, 2018. PMID: 29503244. DOI: 10.1016/S14702045(18)30190-6

92 Drilon A, Laetsch TW, Kummar S, DuBois SG, Lassen UN, Demetri GD, Nathenson M, Doebele RC, Farago AF, Pappo AS, Turpin B, Dowlati A, Brose MS, Mascarenhas L, Federman N, Berlin J, El-Deiry WS, Baik C, Deeken J, Boni V, Nagasubramanian R, Taylor M, Rudzinski ER, Meric-Bernstam F, Sohal DPS, Ma PC, Raez LE, Hechtman JF, Benayed R, Ladanyi M, Tuch BB, Ebata K, Cruickshank S, Ku NC, Cox MC, Hawkins DS, Hong DS and Hyman DM: Efficacy of larotrectinib in TRK fusion-positive cancers in adults and children. N Engl J Med 378(8): 731-739, 2018. PMID: 29466156. DOI: 10.1056/NEJMoa1714448

93 Kheder ES and Hong DS: Emerging targeted therapy for tumors with NTRK fusion proteins. Clin Cancer Res 24(23): 58075814, 2018. PMID: 29986850. DOI: 10.1158/1078-0432.CCR$18-1156$

94 Gambella A, Senetta R, Collemi G, Vallero SG, Monticelli M, Cofano F, Zeppa P, Garbossa D, Pellerino A, Rudà R, Soffietti R, Fagioli F, Papotti M, Cassoni P and Bertero L: NTRK fusions in central nervous system tumors: A rare, but worthy target. Int J Mol Sci 21(3):753, 2020. PMID: 31979374. DOI: $10.3390 / \mathrm{ijms} 21030753$

95 Marcus L, Donoghue M, Aungst S, Myers CE, Helms WS, Shen G, Zhao H, Stephens O, Keegan P and Pazdur R: FDA approval summary: Entrectinib for the treatment of NTRK gene fusion solid tumors. Clin Cancer Res 27(4): 928-932, 2021. PMID: 32967940. DOI: 10.1158/1078-0432.CCR-20-2771

96 Olsen TK, Panagopoulos I, Meling TR, Micci F, Gorunova L, Thorsen J, Due-Tønnessen B, Scheie D, Lund-Iversen M, Krossnes B, Saxhaug C, Heim S and Brandal P: Fusion genes with ALK as recurrent partner in ependymoma-like gliomas: A new brain tumor entity? Neuro Oncol 17(10): 1365-1373, 2015. PMID: 25795305. DOI: 10.1093/neuonc/nov039 
97 Shimada Y, Kohno T, Ueno H, Ino Y, Hayashi H, Nakaoku T, Sakamoto Y, Kondo S, Morizane C, Shimada K, Okusaka T and Hiraoka N: An oncogenic $A L K$ fusion and an RRAS mutation in $K R A S$ mutation-negative pancreatic ductal adenocarcinoma. Oncologist 22(2): 158-164, 2017. PMID: 28167572. DOI: 10.1634/theoncologist.2016-0194

98 Subbiah V, McMahon C, Patel S, Zinner R, Silva EG, Elvin JA, Subbiah IM, Ohaji C, Ganeshan DM, Anand D, Levenback CF, Berry J, Brennan T, Chmielecki J, Chalmers ZR, Mayfield J, Miller VA, Stephens PJ, Ross JS and Ali SM: STUMP un"stumped": Anti-tumor response to anaplastic lymphoma kinase (ALK) inhibitor based targeted therapy in uterine inflammatory myofibroblastic tumor with myxoid features harboring DCTN1-ALK fusion. J Hematol Oncol 8: 66, 2015. PMID: 26062823. DOI: 10.1186/s13045-015-0160-2

99 Ji JH, Oh YL, Hong M, Yun JW, Lee HW, Kim D, Ji Y, Kim DH, Park WY, Shin HT, Kim KM, Ahn MJ, Park K and Sun JM: Identification of driving ALK fusion genes and genomic landscape of medullary thyroid cancer. PLoS Genet 11(8): e1005467, 2015. PMID: 26295973. DOI: 10.1371/journal.pgen.1005467

$100 \mathrm{He}$ Z, Wu X, Ma S, Zhang C, Zhang Z, Wang S, Yu S and Wang Q: Next-generation sequencing identified a novel WDPCP-ALK fusion sensitive to crizotinib in lung adenocarcinoma. Clin Lung Cancer 20(5): e548-e551, 2019. PMID: 31281052. DOI: 10.1016/j.cllc.2019.06.001

101 Qin BD, Jiao XD, Liu K, Wu Y and Zang YS: Identification of a novel EML4-ALK, BCL11A-ALK double-fusion variant in lung adenocarcinoma using next-generation sequencing and response to crizotinib. J Thorac Oncol 14(6): e115-e117, 2019. PMID: 31122560. DOI: 10.1016/j.jtho.2019.01.032

102 Tian Q, Deng WJ and Li ZW: Identification of a novel crizotinibsensitive BCL11A-ALK gene fusion in a nonsmall cell lung cancer patient. Eur Respir J 49(4): 2017. PMID: 28404650. DOI: 10.1183/13993003.02149-2016

103 Chen Y, Zhang X, Jiang Q, Wang B, Wang Y and Junrong Y: Lung adenocarcinoma with a novel SRBD1-ALK fusion responding to crizotinib. Lung Cancer 146: 370-372, 2020. PMID: 32527613. DOI: 10.1016/j.lungcan.2020.04.031

104 Hou X, Xu H and Chen L: SRBD1-ALK, a novel ALK fusion gene identified in an adenocarcinoma patient by next-generation sequencing. J Thorac Oncol 14(4): e72-e73, 2019. PMID: 30922581. DOI: 10.1016/j.jtho.2018.11.027

105 Su C, Jiang Y, Jiang W, Wang H, Liu S, Shao Y, Zhao W, Ning $\mathrm{R}$ and $\mathrm{Yu} \mathrm{Q}: S T R N-A L K$ fusion in lung adenocarcinoma with excellent response upon alectinib treatment: A case report and literature review. Onco Targets Ther 13: 12515-12519, 2020. PMID: 33311990. DOI: 10.2147/OTT.S282933

106 Yang Y, Qin SK, Zhu J, Wang R, Li YM, Xie ZY and Wu Q: A rare $S T R N-A L K$ fusion in lung adenocarcinoma identified using next-generation sequencing-based circulating tumor DNA profiling exhibits excellent response to crizotinib. Mayo Clin Proc Innov Qual Outcomes 1(1): 111-116, 2017. PMID: 30225407. DOI: 10.1016/j.mayocpiqo.2017.04.003

107 Rüschoff JH, Gradhand E, Kahraman A, Rees H, Ferguson JL, Curioni-Fontecedro A, Zoche M, Moch H and Vrugt B: STRN $A L K$ rearranged malignant peritoneal mesothelioma with dramatic response following ceritinib treatment. JCO Precis Oncol 3: 2019. PMID: 32914035. DOI: 10.1200/PO.19.00048

108 Pérot G, Soubeyran I, Ribeiro A, Bonhomme B, Savagner F, Boutet-Bouzamondo N, Hostein I, Bonichon F, Godbert Y and
Chibon F: Identification of a recurrent STRN/ALK fusion in thyroid carcinomas. PLoS One 9(1): e87170, 2014. PMID: 24475247. DOI: 10.1371/journal.pone.0087170

109 Mano H: ALKoma: A cancer subtype with a shared target. Cancer Discov 2(6): 495-502, 2012. PMID: 22614325. DOI: 10.1158/2159-8290.CD-12-0009

110 Iragavarapu C, Mustafa M, Akinleye A, Furqan M, Mittal V, Cang S and Liu D: Novel ALK inhibitors in clinical use and development. J Hematol Oncol 8: 17, 2015. PMID: 25888090. DOI: $10.1186 / \mathrm{s} 13045-015-0122-8$

111 Mano H: Second-generation ALK inhibitors. Clin Adv Hematol Oncol 13(7): 416-417, 2015. PMID: 26353035.

112 Rolfo C, Ruiz R, Giovannetti E, Gil-Bazo I, Russo A, Passiglia F, Giallombardo M, Peeters M and Raez L: Entrectinib: A potent new TRK, ROS1, and ALK inhibitor. Expert Opin Investig Drugs 24(11): 1493-1500, 2015. PMID: 26457764. DOI: 10.1517/13543784.2015.1096344

113 Chan EL, Chin CH and Lui VW: An update of ALK inhibitors in human clinical trials. Future Oncol 12(1): 71-81, 2016. PMID: 26618223. DOI: 10.2217 /fon. 15.293

114 Farina F and Gambacorti-Passerini C: ALK inhibitors for clinical use in cancer therapy. Front Biosci (Elite Ed) 8: 46-60, 2016. PMID: 26709645.

115 Beardslee T and Lawson J: Alectinib and brigatinib: New secondgeneration ALK inhibitors for the treatment of non-small cell lung cancer. J Adv Pract Oncol 9(1): 94-101, 2018. PMID: 30564472 .

116 Vendrell JA, Taviaux S, Béganton B, Godreuil S, Audran P, Grand D, Clermont E, Serre I, Szablewski V, Coopman P, Mazières J, Costes V, Pujol JL, Brousset P, Rouquette I and Solassol J: Detection of known and novel ALK fusion transcripts in lung cancer patients using next-generation sequencing approaches. Sci Rep 7(1): 12510, 2017. PMID: 28970558. DOI: 10.1038/s41598-017-12679-8

117 Kaufmann I, Martin G, Friedlein A, Langen H and Keller W: Human Fip1 is a subunit of CPSF that binds to U-rich RNA elements and stimulates poly(A) polymerase. EMBO J 23(3): 616626, 2004. PMID: 14749727. DOI: 10.1038/sj.emboj. 7600070

118 Claesson-Welsh L, Eriksson A, Westermark B and Heldin CH: cDNA cloning and expression of the human A-type platelet-derived growth factor (PDGF) receptor establishes structural similarity to the B-type PDGF receptor. Proc Natl Acad Sci USA 86(13): 49174921, 1989. PMID: 2544881. DOI: 10.1073/pnas.86.13.4917

119 Matsui T, Heidaran M, Miki T, Popescu N, La Rochelle W, Kraus $\mathrm{M}$, Pierce $\mathrm{J}$ and Aaronson S: Isolation of a novel receptor cDNA establishes the existence of two PDGF receptor genes. Science 243(4892): 800-804, 1989. PMID: 2536956. DOI: 10.1126/ science. 2536956

120 Chen PH, Chen X and He X: Platelet-derived growth factors and their receptors: Structural and functional perspectives. Biochim Biophys Acta 1834(10): 2176-2186, 2013. PMID: 23137658. DOI: 10.1016/j.bbapap.2012.10.015

121 Robinson DR, Wu YM and Lin SF: The protein tyrosine kinase family of the human genome. Oncogene 19(49): 5548-5557, 2000. PMID: 11114734. DOI: 10.1038/sj.onc.1203957

122 Reilly JT: Class III receptor tyrosine kinases: Role in leukaemogenesis. Br J Haematol 116(4): 744-757, 2002. PMID: 11886377. DOI: 10.1046/j.0007-1048.2001.03294.x

123 Berenstein R: Class III receptor tyrosine kinases in acute leukemia - Biological functions and modern laboratory analysis. 
Biomark Insights 10(Suppl 3): 1-14, 2015. PMID: 26309392. DOI: 10.4137/BMI.S22433

124 Ségaliny AI, Tellez-Gabriel M, Heymann MF and Heymann D: Receptor tyrosine kinases: Characterisation, mechanism of action and therapeutic interests for bone cancers. J Bone Oncol 4(1): 112, 2015. PMID: 26579483. DOI: 10.1016/j.jbo.2015.01.001

125 Cools J, DeAngelo DJ, Gotlib J, Stover EH, Legare RD, Cortes J, Kutok J, Clark J, Galinsky I, Griffin JD, Cross NC, Tefferi A, Malone J, Alam R, Schrier SL, Schmid J, Rose M, Vandenberghe P, Verhoef G, Boogaerts M, Wlodarska I, Kantarjian H, Marynen P, Coutre SE, Stone R and Gilliland DG: A tyrosine kinase created by fusion of the PDGFRA and FIP1L1 genes as a therapeutic target of imatinib in idiopathic hypereosinophilic syndrome. N Engl J Med 348(13): 1201-1214, 2003. PMID: 12660384. DOI: 10.1056/NEJMoa025217

126 Bain BJ, Gilliland DG, Horny HP and Vardiman JW: Myeloid and lymphoid neoplasms with eosinophilia and abnormalities of PDGFRA, PDGFRB or FGFR1. In: WHO classification of tumours of haematopoietic and 1Lymphoid tissues. 4th ed. Swerdlow SH, Campo E, Harris NL, Jaffe ES, Pileri SA, Stein $\mathrm{H}$, Thiele J and Vardiman JW (eds.). International Agency for Research on Cancer (IARC) Lyon, pp. 68-73, 2008.

127 Arber DA, Orazi A, Hasserjian R, Thiele J, Borowitz MJ, Le Beau MM, Bloomfield CD, Cazzola M and Vardiman JW: The 2016 revision to the World Health Organization classification of myeloid neoplasms and acute leukemia. Blood 127(20): 2391-2405, 2016. PMID: 27069254. DOI: 10.1182/blood-2016-03-643544

128 Bain BJ, Horny HP, Arber DA, Tefferi A and Hasserjian RP: Myeloid/lymphoid neoplasms with PDGFRA rearrangement. In: WHO classification of tumours of haematopoietic and lymphoid tissues. 5th ed. Swerdlow SH, Campo E, Harris NL, Jaffe ES, Pileri SA, Stein H, Thiele J, Arber DA, Hasserjian RP, Le Beau MM, Orazi A and Siebert R (eds.). International Agency for Research on Cancer (IARC) Lyon, pp. 73-75, 2017.

129 Qu SQ, Qin TJ, Xu ZF, Zhang Y, Ai XF, Li B, Zhang HL, Fang LW, Pan LJ, Hu NB and Xiao ZJ: Long-term outcomes of imatinib in patients with FIP1L1/ PDGFRA associated chronic eosinophilic leukemia: Experience of a single center in China. Oncotarget 7(22): 33229-33236, 2016. PMID: 27120808. DOI: 10.18632 /oncotarget.8906

130 Metzgeroth G, Schwaab J, Naumann N, Jawhar M, Haferlach T, Fabarius A, Hochhaus A, Hofmann WK, Cross NCP and Reiter A: Treatment-free remission in FIP1L1-PDGFRA-positive myeloid/lymphoid neoplasms with eosinophilia after imatinib discontinuation. Blood Adv 4(3): 440-443, 2020. PMID: 31995156. DOI: 10.1182/bloodadvances.2019001111

131 Golub TR, Barker GF, Lovett M and Gilliland DG: Fusion of PDGF receptor beta to a novel ets-like gene, tel, in chronic myelomonocytic leukemia with $\mathrm{t}(5 ; 12)$ chromosomal translocation. Cell 77(2): 307-316, 1994. PMID: 8168137. DOI: 10.1016/0092-8674(94)90322-0

132 Lengline E, Beldjord K, Dombret H, Soulier J, Boissel N and Clappier E: Successful tyrosine kinase inhibitor therapy in a refractory B-cell precursor acute lymphoblastic leukemia with EBF1-PDGFRB fusion. Haematologica 98(11): e146-e148, 2013. PMID: 24186319. DOI: 10.3324/haematol.2013.095372

133 Weston BW, Hayden MA, Roberts KG, Bowyer S, Hsu J, Fedoriw G, Rao KW and Mullighan CG: Tyrosine kinase inhibitor therapy induces remission in a patient with refractory EBF1-PDGFRB-positive acute lymphoblastic leukemia. J Clin
Oncol 31(25): e413-e416, 2013. PMID: 23835704. DOI: 10.1200/JCO.2012.47.6770

134 Gosenca D, Kellert B, Metzgeroth G, Haferlach C, Fabarius A, Schwaab J, Kneba M, Scheid C, Töpelt K, Erben P, Haferlach T, Cross NC, Hofmann WK, Seifarth W and Reiter A: Identification and functional characterization of imatinib-sensitive DTD1PDGFRB and CCDC88C-PDGFRB fusion genes in eosinophiliaassociated myeloid/lymphoid neoplasms. Genes Chromosomes Cancer 53(5): 411-421, 2014. PMID: 24772479. DOI: $10.1002 / \mathrm{gcc} .22153$

135 Cheah CY, Burbury K, Apperley JF, Huguet F, Pitini V, Gardembas M, Ross DM, Forrest D, Genet P, Rousselot P, Patton $\mathrm{N}$, Smith G, Dunbar CE, Ito S, Aguiar RC, Odenike O, Gimelfarb A, Cross NC and Seymour JF: Patients with myeloid malignancies bearing PDGFRB fusion genes achieve durable long-term remissions with imatinib. Blood 123(23): 3574-3577, 2014. PMID: 24687085. DOI: 10.1182/blood-2014-02-555607

136 Appiah-Kubi K, Lan T, Wang Y, Qian H, Wu M, Yao X, Wu Y and Chen Y: Platelet-derived growth factor receptors (PDGFRs) fusion genes involvement in hematological malignancies. Crit Rev Oncol Hematol 109: 20-34, 2017. PMID: 28010895. DOI: 10.1016/j.critrevonc.2016.11.008

137 Horiuchi M, Yoshida M, Yamasaki K, Sakagami R, Aoyama T, Tatsumi N, Tsutsumi M, Nakaya Y, Fuseya H, Yoshimura T, Hayashi Y, Nakao T and Yamane T: Effective treatment with imatinib for acute B-lymphoblastic leukaemia with EBF1PDGFRB fusion. Ann Hematol 2020. PMID: 33150465. DOI: 10.1007/s00277-020-04332-8

138 Oya S, Morishige S, Ozawa H, Sasaki K, Semba Y, Yamasaki Y, Nakamura T, Aoyama K, Seki R, Mouri F, Osaki K, Miyamoto $\mathrm{T}$, Maeda $\mathrm{T}$ and Nagafuji K: Beneficial tyrosine kinase inhibitor therapy in a patient with relapsed BCR-ABL1-like acute lymphoblastic leukemia with CCDC88C-PDGFRB fusion. Int J Hematol 113(2): 285-289, 2021. PMID: 32951102. DOI: 10.1007/s12185-020-03006-5

139 Zimmermann N, Nassiri M, Zhou J, Miller AM and Zhang S: Myeloid neoplasm with a novel cryptic PDGFRB rearrangement detected by next-generation sequencing. Cancer Genet 244: 55-59, 2020. PMID: 32442889. DOI: 10.1016/j.cancergen.2020.03.002

140 Sakurai Y, Sarashina T, Toriumi N, Hatakeyama N, Kanayama T, Imamura T, Osumi T, Ohki K, Kiyokawa N and Azuma H: Bcell precursor-acute lymphoblastic leukemia with EBF1PDGFRB fusion treated with hematopoietic stem cell transplantation and imatinib: A case report and literature review. J Pediatr Hematol Oncol 43(1): e105-e108, 2021. PMID: 32068648. DOI: 10.1097/MPH.0000000000001743

141 Roberts KG, Morin RD, Zhang J, Hirst M, Zhao Y, Su X, Chen SC, Payne-Turner D, Churchman ML, Harvey RC, Chen X, Kasap C, Yan C, Becksfort J, Finney RP, Teachey DT, Maude SL, Tse K, Moore R, Jones S, Mungall K, Birol I, Edmonson MN, Hu Y, Buetow KE, Chen IM, Carroll WL, Wei L, Ma J, Kleppe M, Levine RL, Garcia-Manero G, Larsen E, Shah NP, Devidas M, Reaman G, Smith M, Paugh SW, Evans WE, Grupp SA, Jeha S, Pui CH, Gerhard DS, Downing JR, Willman CL, Loh M, Hunger SP, Marra MA and Mullighan CG: Genetic alterations activating kinase and cytokine receptor signaling in high-risk acute lymphoblastic leukemia. Cancer Cell 22(2): 153166, 2012. PMID: 22897847. DOI: 10.1016/j.ccr.2012.06.005

142 Schwab C, Ryan SL, Chilton L, Elliott A, Murray J, Richardson S, Wragg C, Moppett J, Cummins M, Tunstall O, Parker CA, 
Saha V, Goulden N, Vora A, Moorman AV and Harrison CJ: EBF1-PDGFRB fusion in pediatric B-cell precursor acute lymphoblastic leukemia (BCP-ALL): Genetic profile and clinical implications. Blood 127(18): 2214-2218, 2016. PMID: 26872634. DOI: 10.1182/blood-2015-09-670166

143 Fazio F, Barberi W, Cazzaniga G, Fazio G, Messina M, Della Starza I, De Propris MS, Mancini F, Mohamed S, Del Giudice I, Chiaretti S, Moleti ML, Guarini A, Foà R and Testi AM: Efficacy of imatinib and chemotherapy in a pediatric patient with Philadelphia-like acute lymphoblastic leukemia with Ebfl-Pdgfrb fusion transcript. Leuk Lymphoma 61(2): 469-472, 2020. PMID: 31558067. DOI: 10.1080/10428194.2019.1668938

144 Roberts KG, Li Y, Payne-Turner D, Harvey RC, Yang YL, Pei D, McCastlain K, Ding L, Lu C, Song G, Ma J, Becksfort J, Rusch M, Chen SC, Easton J, Cheng J, Boggs K, SantiagoMorales N, Iacobucci I, Fulton RS, Wen J, Valentine M, Cheng C, Paugh SW, Devidas M, Chen IM, Reshmi S, Smith A, Hedlund E, Gupta P, Nagahawatte P, Wu G, Chen X, Yergeau D, Vadodaria B, Mulder H, Winick NJ, Larsen EC, Carroll WL, Heerema NA, Carroll AJ, Grayson G, Tasian SK, Moore AS, Keller F, Frei-Jones M, Whitlock JA, Raetz EA, White DL, Hughes TP, Guidry Auvil JM, Smith MA, Marcucci G, Bloomfield CD, Mrózek K, Kohlschmidt J, Stock W, Kornblau SM, Konopleva M, Paietta E, Pui CH, Jeha S, Relling MV, Evans WE, Gerhard DS, Gastier-Foster JM, Mardis E, Wilson RK, Loh ML, Downing JR, Hunger SP, Willman CL, Zhang J and Mullighan CG: Targetable kinase-activating lesions in Ph-like acute lymphoblastic leukemia. N Engl J Med 371(11): 10051015, 2014. PMID: 25207766. DOI: 10.1056/NEJMoa1403088

145 Ross DM, Altamura HK, Hahn CN, Nicola M, Yeoman AL, Holloway MR, Geoghegan J, Feng J, Schreiber AW, Branford S, Moore S and Scott HS: Delayed diagnosis leading to acceleratedphase chronic eosinophilic leukemia due to a cytogenetically cryptic, imatinib-responsive TNIP1-PDFGRB fusion gene. Leukemia 30(6): 1402-1405, 2016. PMID: 26503642. DOI: 10.1038/leu.2015.301

146 Maccaferri M, Pierini V, Di Giacomo D, Zucchini P, Forghieri F, Bonacorsi G, Paolini A, Quadrelli C, Giacobbi F, Fontana F, Cappelli G, Potenza L, Marasca R, Luppi M and Mecucci C: The importance of cytogenetic and molecular analyses in eosinophilia-associated myeloproliferative neoplasms: An unusual case with normal karyotype and TNIP1- PDGFRB rearrangement and overview of PDGFRB partner genes. Leuk Lymphoma 58(2): 489-493, 2017. PMID: 27337990. DOI: 10.1080/10428194.2016.1197396

147 Liu YF, Wang BY, Zhang WN, Huang JY, Li BS, Zhang M, Jiang L, Li JF, Wang MJ, Dai YJ, Zhang ZG, Wang Q, Kong J, Chen B, Zhu YM, Weng XQ, Shen ZX, Li JM, Wang J, Yan XJ, Li Y, Liang YM, Liu L, Chen XQ, Zhang WG, Yan JS, Hu JD, Shen SH, Chen J, Gu LJ, Pei D, Li Y, Wu G, Zhou X, Ren RB, Cheng C, Yang JJ, Wang KK, Wang SY, Zhang J, Mi JQ, Pui CH, Tang JY, Chen Z and Chen SJ: Genomic profiling of adult and pediatric B-cell acute lymphoblastic leukemia. EBioMedicine 8: 173-183, 2016. PMID: 27428428. DOI: 10.1016/j.ebiom.2016.04.038

148 Al-Ibraheemi A, Folpe AL, Perez-Atayde AR, Perry K, Hofvander J, Arbajian E, Magnusson L, Nilsson J and Mertens F: Aberrant receptor tyrosine kinase signaling in lipofibromatosis: A clinicopathological and molecular genetic study of 20 cases. Mod Pathol 32(3): 423-434, 2019. PMID: 30310176. DOI: 10.1038/s41379-018-0150-3
149 Birchmeier C, Birnbaum D, Waitches G, Fasano O and Wigler M: Characterization of an activated human ros gene. Mol Cell Biol 6(9): 3109-3116, 1986. PMID: 3785223. DOI: 10.1128/ mcb.6.9.3109

150 Matsushime H, Wang LH and Shibuya M: Human c-ros-1 gene homologous to the v-ros sequence of UR2 sarcoma virus encodes for a transmembrane receptorlike molecule. Mol Cell Biol 6(8): 3000-3004, 1986. PMID: 3023956. DOI: $10.1128 / \mathrm{mcb} .6 .8 .3000$

151 Nagarajan L, Louie E, Tsujimoto Y, Balduzzi PC, Huebner K and Croce CM: The human c-ros gene (ROS) is located at chromosome region 6q16- -6q22. Proc Natl Acad Sci USA 83(17): 6568-6572, 1986. PMID: 3529088. DOI: 10.1073/pnas.83.17.6568

152 Birchmeier C, Sharma S and Wigler M: Expression and rearrangement of the ROS 1 gene in human glioblastoma cells. Proc Natl Acad Sci USA 84(24): 9270-9274, 1987. PMID: 2827175. DOI: $10.1073 /$ pnas.84.24.9270

153 Rabin M, Birnbaum D, Young D, Birchmeier C, Wigler M and Ruddle FH: Human ros 1 and mas 1 oncogenes located in regions of chromosome 6 associated with tumor-specific rearrangements. Oncogene Res 1(2): 169-178, 1987. PMID: 3329713.

154 Satoh H, Yoshida MC, Matsushime H, Shibuya M and Sasaki M: Regional localization of the human c-ros-1 on $6 \mathrm{q} 22$ and flt on 13q12. Jpn J Cancer Res 78(8): 772-775, 1987. PMID: 3115921.

155 Birchmeier $\mathrm{C}$, O'Neill $\mathrm{K}$, Riggs $\mathrm{M}$ and Wigler $\mathrm{M}$ : Characterization of ROS1 cDNA from a human glioblastoma cell line. Proc Natl Acad Sci USA 87(12): 4799-4803, 1990. PMID: 2352949. DOI: $10.1073 /$ pnas.87.12.4799

156 Sharma S, Birchmeier C, Nikawa J, O’Neill K, Rodgers L and Wigler M: Characterization of the ros1-gene products expressed in human glioblastoma cell lines. Oncogene Res 5(2): 91-100, 1989. PMID: 2691958.

157 Zhao JF and Sharma S: Expression of the ROS1 oncogene for tyrosine receptor kinase in adult human meningiomas. Cancer Genet Cytogenet 83(2): 148-154, 1995. PMID: 7553586. DOI: 10.1016/0165-4608(95)00043-o

158 Maxwell M, Galanopoulos T, Nevillegolden J and Antoniades H: Overexpression of the ros 1 gene in primary human gliomas may contribute to malignant progression. Int J Oncol 8(4): 713-718, 1996. PMID: 21544418. DOI: 10.3892/ijo.8.4.713

159 Uguen A and De Braekeleer M: ROS1 fusions in cancer: A review. Future Oncol 12(16): 1911-1928, 2016. PMID: 27256160. DOI: $10.2217 /$ fon-2016-0050

160 Drilon A, Jenkins C, Iyer S, Schoenfeld A, Keddy C and Davare MA: ROS1-dependent cancers - biology, diagnostics and therapeutics. Nat Rev Clin Oncol 18(1): 35-55, 2021. PMID: 32760015. DOI: 10.1038/s41571-020-0408-9

161 Huang RSP, Haberberger J, Sokol E, Schrock AB, Danziger N, Madison R, Trabucco S, Jin D, Pavlick D, Ramanan V, Hole K, McGregor K, Venstrom J and Ross JS: Clinicopathologic, genomic and protein expression characterization of 356 ROS1 fusion driven solid tumors cases. Int J Cancer 148(7): 1778-1788, 2021. PMID: 33336398. DOI: 10.1002/ijc.33447

162 Lan S, Li H, Liu Y, Xu J, Huang Z, Yan S, Zhang Q and Cheng Y: A novel ROS1-FBXL17 fusion co-existing with CD74-ROS1 fusion may improve sensitivity to crizotinib and prolong progression-free survival of patients with lung adenocarcinoma. Onco Targets Ther 13: 11499-11504, 2020. PMID: 33204104. DOI: $10.2147 / O T T . S 278907$

163 Li J, Liu L, Zhang Q, Huang Y, Zhang Y, Gan X, Liu S, Yue Z and Wei Y: A novel TJP1-ROS1 fusion in malignant peripheral 
nerve sheath tumor responding to crizotinib: A case report. Medicine (Baltimore) 99(26): e20725, 2020. PMID: 32590748. DOI: 10.1097/MD.0000000000020725

164 Suehara Y, Kohsaka S, Hayashi T, Akaike K, Kurisaki-Arakawa A, Sato S, Kobayashi E, Mizuno S, Ueno T, Morii T, Okuma T, Kurihara T, Hasegawa N, Sano K, Sasa K, Okubo T, Kim Y, Mano H and Saito T: Identification of a novel MAN1A1-ROS1 fusion gene through mRNA-based Screening for tyrosine kinase gene aberrations in a patient with leiomyosarcoma. Clin Orthop Relat Res 2020. PMID: 33196586. DOI: 10.1097/CORR. 0000000000001548

165 Zhang Y, Yu M, Yuan M, Chen R and Huang MJ: Identification of a novel RBPMS-ROS1 fusion in an adolescent patient with microsatellite-instable advanced lung adenocarcinoma sensitive to crizotinib: A case report. Clin Lung Cancer 21(2): e78-e83, 2020. PMID: 31722815. DOI: 10.1016/j.cllc.2019.09.003

166 Davare MA, Henderson JJ, Agarwal A, Wagner JP, Iyer SR, Shah N, Woltjer R, Somwar R, Gilheeney SW, DeCarvalo A, Mikkelson T, Van Meir EG, Ladanyi M and Druker BJ: Rare but recurrent ROS1 fusions resulting from chromosome 6q22 microdeletions are targetable oncogenes in glioma. Clin Cancer Res 24(24): 6471-6482, 2018. PMID: 30171048. DOI: 10.1158/1078-0432.CCR-18-1052

167 Morris TA, Khoo C and Solomon BJ: Targeting ROS1 rearrangements in non-small cell lung cancer: Crizotinib and newer generation tyrosine kinase inhibitors. Drugs 79(12): 1277-1286, 2019. PMID: 31313100. DOI: 10.1007/s40265-019-01164-3

168 Richardson TE, Tang K, Vasudevaraja V, Serrano J, William CM, Mirchia K, Pierson CR, Leonard JR, AbdelBaki MS, Schieffer KM, Cottrell CE, Tovar-Spinoza Z, Comito MA, Boué DR, Jour $\mathrm{G}$ and Snuderl M: GOPC-ROS1 fusion due to microdeletion at $6 \mathrm{q} 22$ is an oncogenic driver in a subset of pediatric gliomas and glioneuronal tumors. J Neuropathol Exp Neurol 78(12): 10891099, 2019. PMID: 31626289. DOI: 10.1093/jnen/nlz093

169 Araujo JM, Gomez AC, Pinto JA, Rolfo C and Raez LE: Profile of entrectinib in the treatment of ROS1-positive non-small cell lung cancer: Evidence to date. Hematol Oncol Stem Cell Ther : , 2020. PMID: 33290717. DOI: 10.1016/j.hemonc.2020.11.005

170 Fischer H, Ullah M, de la Cruz CC, Hunsaker T, Senn C, Wirz T, Wagner B, Draganov D, Vazvaei F, Donzelli M, Paehler A, Merchant M and Yu L: Entrectinib, a TRK/ROS1 inhibitor with anti-CNS tumor activity: Differentiation from other inhibitors in its class due to weak interaction with P-glycoprotein. Neuro Oncol 22(6): 819-829, 2020. PMID: 32383735. DOI: 10.1093/neuonc/noaa052

171 Sehgal K, Piper-Vallillo AJ, Viray H, Khan AM, Rangachari D and Costa DB: Cases of ROS1-rearranged lung cancer: When to use crizotinib, entrectinib, lorlatinib, and beyond? Precis Cancer Med 3: 2020. PMID: 32776005. DOI: 10.21037/pcm-2020-potb02

172 Charest A, Lane K, McMahon K, Park J, Preisinger E, Conroy $\mathrm{H}$ and Housman D: Fusion of FIG to the receptor tyrosine kinase ROS in a glioblastoma with an interstitial del(6)(q21q21). Genes Chromosomes Cancer 37(1): 58-71, 2003. PMID: 12661006. DOI: $10.1002 / \mathrm{gcc} .10207$

173 Charest A, Kheifets V, Park J, Lane K, McMahon K, Nutt CL and Housman D: Oncogenic targeting of an activated tyrosine kinase to the golgi apparatus in a glioblastoma. Proc Natl Acad Sci USA 100(3): 916-921, 2003. PMID: 12538861. DOI: $10.1073 /$ pnas. 242741799
174 Gu TL, Deng X, Huang F, Tucker M, Crosby K, Rimkunas V, Wang Y, Deng G, Zhu L, Tan Z, Hu Y, Wu C, Nardone J, MacNeill J, Ren J, Reeves C, Innocenti G, Norris B, Yuan J, Yu J, Haack H, Shen B, Peng C, Li H, Zhou X, Liu X, Rush J and Comb MJ: Survey of tyrosine kinase signaling reveals ROS kinase fusions in human cholangiocarcinoma. PLoS One 6(1): e15640, 2011. PMID: 21253578. DOI: 10.1371/journal.pone.0015640

175 Suehara Y, Arcila M, Wang L, Hasanovic A, Ang D, Ito T, Kimura Y, Drilon A, Guha U, Rusch V, Kris MG, Zakowski MF, Rizvi N, Khanin R and Ladanyi M: Identification of KIF5B-RET and GOPC-ROS1 fusions in lung adenocarcinomas through a comprehensive mRNA-based screen for tyrosine kinase fusions. Clin Cancer Res 18(24): 6599-6608, 2012. PMID: 23052255. DOI: $10.1158 / 1078-0432 . C C R-12-0838$

176 Guerreiro Stucklin AS, Ryall S, Fukuoka K, Zapotocky M, Lassaletta A, Li C, Bridge T, Kim B, Arnoldo A, Kowalski PE, Zhong Y, Johnson M, Li C, Ramani AK, Siddaway R, Nobre LF, de Antonellis P, Dunham C, Cheng S, Boué DR, Finlay JL, Coven SL, de Prada I, Perez-Somarriba M, Faria CC, Grotzer MA, Rushing E, Sumerauer D, Zamecnik J, Krskova L, Garcia Ariza M, Cruz O, Morales La Madrid A, Solano P, Terashima K, Nakano Y, Ichimura K, Nagane M, Sakamoto H, Gil-da-Costa MJ, Silva R, Johnston DL, Michaud J, Wilson B, van Landeghem FKH, Oviedo A, McNeely PD, Crooks B, Fried I, Zhukova N, Hansford JR, Nageswararao A, Garzia L, Shago M, Brudno M, Irwin MS, Bartels U, Ramaswamy V, Bouffet E, Taylor MD, Tabori U and Hawkins C: Alterations in ALK/ROS1/NTRK/MET drive a group of infantile hemispheric gliomas. Nat Commun 10(1): 4343, 2019. PMID: 31554817. DOI: 10.1038/s41467-019-12187-5

177 Dong D, Shen G, Da Y, Zhou M, Yang G, Yuan M and Chen R: Successful treatment of patients with refractory high-grade serous ovarian cancer with GOPC-ROS1 fusion using crizotinib: A case report. Oncologist 25(11): e1720-e1724, 2020. PMID: 32652753. DOI: 10.1634/theoncologist.2019-0609

178 Arai Y, Totoki Y, Takahashi H, Nakamura H, Hama N, Kohno T, Tsuta K, Yoshida A, Asamura H, Mutoh M, Hosoda F, Tsuda H and Shibata T: Mouse model for ROS1-rearranged lung cancer. PLoS One 8(2): e56010, 2013. PMID: 23418494. DOI: 10.1371/journal.pone. 0056010

179 Yoshida A, Kohno T, Tsuta K, Wakai S, Arai Y, Shimada Y, Asamura H, Furuta K, Shibata T and Tsuda H: ROS1-rearranged lung cancer: A clinicopathologic and molecular study of 15 surgical cases. Am J Surg Pathol 37(4): 554-562, 2013. PMID: 23426121. DOI: 10.1097/PAS.0b013e3182758fe6

180 Li H, Pan Y, Wang R, Li Y, Sun Y and Chen H: Response to crizotinib observed in metastatic mediastinum lymph node from a non-small cell lung cancer patient harboring EZR-ROS1 fusion. J Cancer Res Clin Oncol 141(1): 185-187, 2015. PMID: 25230898. DOI: $10.1007 / \mathrm{s} 00432-014-1821-1$

181 Lin JJ and Shaw AT: Recent advances in targeting ROS1 in lung cancer. J Thorac Oncol 12(11): 1611-1625, 2017. PMID: 28818606. DOI: $10.1016 /$ j.jtho.2017.08.002

182 Dong L, Xia J, Zhang J, Zhang Y, Zhu N, Zhang P, Zhang Y, Zhang $\mathrm{X}$ and Li S: Long-term progression-free survival in an advanced lung adenocarcinoma patient harboring EZR-ROS1 rearrangement: A case report. BMC Pulm Med 18(1): 13, 2018. PMID: 29361925. DOI: 10.1186/s12890-018-0585-9

183 Capizzi E, Dall'Olio FG, Gruppioni E, Sperandi F, Altimari A, Giunchi F, Fiorentino M and Ardizzoni A: Clinical significance of ROS1 5' deletions in non-small cell lung cancer. Lung Cancer 
135: 88-91, 2019. PMID: 31447007. DOI: 10.1016/j.lungcan. 2019.07.017

184 He Y, Sheng W, Hu W, Lin J, Liu J, Yu B, Mao X, Zhang L, Huang $\mathrm{J}$ and Wang G: Different types of ROS1 fusion partners yield comparable efficacy to crizotinib. Oncol Res 27(8): 901-910, 2019. PMID: 30940295. DOI: 10.3727/096504019X15509372008132

185 Giacomini CP, Sun S, Varma S, Shain AH, Giacomini MM, Balagtas J, Sweeney RT, Lai E, Del Vecchio CA, Forster AD, Clarke N, Montgomery KD, Zhu S, Wong AJ, van de Rijn M, West RB and Pollack JR: Breakpoint analysis of transcriptional and genomic profiles uncovers novel gene fusions spanning multiple human cancer types. PLoS Genet 9(4): e1003464, 2013. PMID: 23637631. DOI: 10.1371/journal.pgen.1003464

186 Stransky N, Cerami E, Schalm S, Kim JL and Lengauer C: The landscape of kinase fusions in cancer. Nat Commun 5: 4846, 2014. PMID: 25204415. DOI: $10.1038 /$ ncomms5846

187 Yang L, Lee MS, Lu H, Oh DY, Kim YJ, Park D, Park G, Ren X, Bristow CA, Haseley PS, Lee S, Pantazi A, Kucherlapati R, Park WY, Scott KL, Choi YL and Park PJ: Analyzing somatic genome rearrangements in human cancers by using whole-exome sequencing. Am J Hum Genet 98(5): 843-856, 2016. PMID: 27153396. DOI: 10.1016/j.ajhg.2016.03.017

188 Johnson A, Severson E, Gay L, Vergilio JA, Elvin J, Suh J, Daniel S, Covert M, Frampton GM, Hsu S, Lesser GJ, StognerUnderwood K, Mott RT, Rush SZ, Stanke JJ, Dahiya S, Sun J, Reddy P, Chalmers ZR, Erlich R, Chudnovsky Y, Fabrizio D, Schrock AB, Ali S, Miller V, Stephens PJ, Ross J, Crawford JR and Ramkissoon SH: Comprehensive genomic profiling of 282 pediatric low- and high-grade gliomas reveals genomic drivers, tumor mutational burden, and hypermutation signatures. Oncologist 22(12): 1478-1490, 2017. PMID: 28912153. DOI: 10.1634/theoncologist.2017-0242

189 Wang X, Angelis N and Thein SL: MYB - A regulatory factor in hematopoiesis. Gene 665: 6-17, 2018. PMID: 29704633. DOI: 10.1016/j.gene.2018.04.065

190 Fry EA and Inoue K: c-MYB and DMTF1 in cancer. Cancer Invest 37(1): 46-65, 2019. PMID: 30599775. DOI: 10.1080/ 07357907.2018.1550090

191 Ness SA: Myb binding proteins: Regulators and cohorts in transformation. Oncogene 18(19): 3039-3046, 1999. PMID: 10378699. DOI: $10.1038 /$ sj.onc. 1202726

$192 \mathrm{Oh}$ IH and Reddy EP: The myb gene family in cell growth, differentiation and apoptosis. Oncogene 18(19): 3017-3033, 1999. PMID: 10378697. DOI: 10.1038/sj.onc.1202839

193 Ramsay RG and Gonda TJ: MYB function in normal and cancer cells. Nat Rev Cancer 8(7): 523-534, 2008. PMID: 18574464. DOI: $10.1038 / \mathrm{nrc} 2439$

194 Kastan MB, Slamon DJ and Civin CI: Expression of protooncogene c-myb in normal human hematopoietic cells. Blood 73(6): 1444-1451, 1989. PMID: 2469491.

195 Zorbas M, Sicurella C, Bertoncello I, Venter D, Ellis S, Mucenski ML and Ramsay RG: c-Myb is critical for murine colon development. Oncogene 18(42): 5821-5830, 1999. PMID: 10523863. DOI: $10.1038 /$ sj.onc. 1202971

196 Malaterre J, Mantamadiotis T, Dworkin S, Lightowler S, Yang Q, Ransome MI, Turnley AM, Nichols NR, Emambokus NR, Frampton $\mathrm{J}$ and Ramsay RG: c-Myb is required for neural progenitor cell proliferation and maintenance of the neural stem cell niche in adult brain. Stem Cells 26(1): 173-181, 2008. PMID: 17901403. DOI: 10.1634/stemcells.2007-0293
197 Uttarkar S, Frampton J and Klempnauer KH: Targeting the transcription factor Myb by small-molecule inhibitors. Exp Hematol 47: 31-35, 2017. PMID: 28017646. DOI: 10.1016/j.exphem.2016.12.003

198 Liu X, Xu Y, Han L and Yi Y: Reassessing the potential of Mybtargeted anti-cancer therapy. J Cancer 9(7): 1259-1266, 2018. PMID: 29675107. DOI: 10.7150/jca.23992

199 Li ZZ, Kondo T, Murata T, Ebersole TA, Nishi T, Tada K, Ushio Y, Yamamura $\mathrm{K}$ and Abe K: Expression of Hqk encoding a KH RNA binding protein is altered in human glioma. Jpn J Cancer Res 93(2): 167-177, 2002. PMID: 11856480. DOI: 10.1111/j.1349-7006.2002.tb01255.x

200 Backx L, Fryns JP, Marcelis C, Devriendt K, Vermeesch J and Van Esch H: Haploinsufficiency of the gene Quaking (QKI) is associated with the $6 \mathrm{q}$ terminal deletion syndrome. Am J Med Genet A 152A(2): 319-326, 2010. PMID: 20082458. DOI: 10.1002/ajmg.a.33202

201 Caines R, Cochrane A, Kelaini S, Vila-Gonzalez M, Yang C, Eleftheriadou M, Moez A, Stitt AW, Zeng L, Grieve DJ and Margariti A: The RNA-binding protein QKI controls alternative splicing in vascular cells, producing an effective model for therapy. J Cell Sci 132(16): 2019. PMID: 31331967. DOI: $10.1242 /$ jcs 230276

202 Roth JJ, Santi M, Rorke-Adams LB, Harding BN, Busse TM, Tooke LS and Biegel JA: Diagnostic application of high resolution single nucleotide polymorphism array analysis for children with brain tumors. Cancer Genet 207(4): 111-123, 2014. PMID: 24767714. DOI: 10.1016/j.cancergen.2014.03.002

203 Zhang J, Wu G, Miller CP, Tatevossian RG, Dalton JD, Tang B, Orisme W, Punchihewa C, Parker M, Qaddoumi I, Boop FA, Lu C, Kandoth C, Ding L, Lee R, Huether R, Chen X, Hedlund E, Nagahawatte P, Rusch M, Boggs K, Cheng J, Becksfort J, Ma J, Song G, Li Y, Wei L, Wang J, Shurtleff S, Easton J, Zhao D, Fulton RS, Fulton LL, Dooling DJ, Vadodaria B, Mulder HL, Tang C, Ochoa K, Mullighan CG, Gajjar A, Kriwacki R, Sheer D, Gilbertson RJ, Mardis ER, Wilson RK, Downing JR, Baker SJ, Ellison DW and St. Jude Children's Research HospitalWashington University Pediatric Cancer Genome Project: Wholegenome sequencing identifies genetic alterations in pediatric lowgrade gliomas. Nat Genet 45(6): 602-612, 2013. PMID: 23583981. DOI: $10.1038 / \mathrm{ng} .2611$

204 Bandopadhayay P, Ramkissoon LA, Jain P, Bergthold G, Wala J, Zeid R, Schumacher SE, Urbanski L, O'Rourke R, Gibson WJ, Pelton K, Ramkissoon SH, Han HJ, Zhu Y, Choudhari N, Silva A, Boucher K, Henn RE, Kang YJ, Knoff D, Paolella BR, Gladden-Young A, Varlet P, Pages M, Horowitz PM, Federation A, Malkin H, Tracy AA, Seepo S, Ducar M, Van Hummelen P, Santi M, Buccoliero AM, Scagnet M, Bowers DC, Giannini C, Puget S, Hawkins C, Tabori U, Klekner A, Bognar L, Burger PC, Eberhart C, Rodriguez FJ, Hill DA, Mueller S, Haas-Kogan DA, Phillips JJ, Santagata S, Stiles CD, Bradner JE, Jabado N, Goren A, Grill J, Ligon AH, Goumnerova L, Waanders AJ, Storm PB, Kieran MW, Ligon KL, Beroukhim R and Resnick AC: MYB-QKI rearrangements in angiocentric glioma drive tumorigenicity through a tripartite mechanism. Nat Genet 48(3): 273-282, 2016. PMID: 26829751. DOI: $10.1038 / \mathrm{ng} .3500$

205 D'Aronco L, Rouleau C, Gayden T, Crevier L, Décarie JC, Perreault S, Jabado N, Bandopadhayay P, Ligon KL and Ellezam $\mathrm{B}$ : Brainstem angiocentric gliomas with MYB-QKI 
rearrangements. Acta Neuropathol 134(4): 667-669, 2017. PMID: 28803398. DOI: 10.1007/s00401-017-1763-1

206 Lake JA, Donson AM, Prince E, Davies KD, Nellan A, Green AL, Mulcahy Levy J, Dorris K, Vibhakar R, Hankinson TC, Foreman NK, Ewalt MD, Kleinschmidt-DeMasters BK, Hoffman LM and Gilani A: Targeted fusion analysis can aid in the classification and treatment of pediatric glioma, ependymoma, and glioneuronal tumors. Pediatr Blood Cancer 67(1): e28028, 2020. PMID: 31595628 . DOI: $10.1002 / p b c .28028$

207 Lian F, Wang LM, Qi XL, Liu LN, Wang XF, Fu J, Xiong J, Lu $\mathrm{DH}$ and Piao YS: MYB-QKI rearrangement in angiocentric glioma. Clin Neuropathol 39(6): 263-270, 2020. PMID: 32589128. DOI: $10.5414 / \mathrm{NP} 301284$

208 Sithanandam G, Kolch W, Duh FM and Rapp UR: Complete coding sequence of a human B-raf cDNA and detection of B-raf protein kinase with isozyme specific antibodies. Oncogene 5(12): 1775-1780, 1990. PMID: 2284096.

209 Eychène A, Barnier JV, Apiou F, Dutrillaux B and Calothy G: Chromosomal assignment of two human B-raf(Rmil) protooncogene loci: B-raf-1 encoding the p94Braf/Rmil and B-raf-2, a processed pseudogene. Oncogene 7(8): 1657-1660, 1992. PMID: 1630826.

210 Sithanandam G, Druck T, Cannizzaro LA, Leuzzi G, Huebner K and Rapp UR: B-raf and a B-raf pseudogene are located on 7q in man. Oncogene 7(4): 795-799, 1992. PMID: 1565476.

211 Leicht DT, Balan V, Kaplun A, Singh-Gupta V, Kaplun L, Dobson $\mathrm{M}$ and Tzivion G: Raf kinases: Function, regulation and role in human cancer. Biochim Biophys Acta 1773(8): 11961212, 2007. PMID: 17555829. DOI: 10.1016/j.bbamcr. 2007.05.001

212 Matallanas D, Birtwistle M, Romano D, Zebisch A, Rauch J, von Kriegsheim A and Kolch W: Raf family kinases: Old dogs have learned new tricks. Genes Cancer 2(3): 232-260, 2011. PMID: 21779496. DOI: $10.1177 / 1947601911407323$

213 Karoulia Z, Gavathiotis E and Poulikakos PI: New perspectives for targeting RAF kinase in human cancer. Nat Rev Cancer 17(11): 676-691, 2017. PMID: 28984291. DOI: 10.1038/ nrc.2017.79

214 Zaman A, Wu W and Bivona TG: Targeting oncogenic BRAF: Past, present, and future. Cancers (Basel) 11(8):1197, 2019. PMID: 31426419. DOI: 10.3390/cancers11081197

215 Pratilas CA, Xing F and Solit DB: Targeting oncogenic BRAF in human cancer. Curr Top Microbiol Immunol 355: 83-98, 2012. PMID: 21818706. DOI: 10.1007/82_2011_162

216 Pisapia P, Pepe F, Iaccarino A, Sgariglia R, Nacchio M, Russo G, Gragnano G, Malapelle U and Troncone G: BRAF: A TwoFaced Janus. Cells 9(12):2549, 2020. PMID: 33260892. DOI: 10.3390/cells9122549

217 Dankner M, Rose AAN, Rajkumar S, Siegel PM and Watson IR: Classifying BRAF alterations in cancer: New rational therapeutic strategies for actionable mutations. Oncogene 37(24): 3183-3199, 2018. PMID: 29540830. DOI: 10.1038/s41388-018-0171-x

218 Proietti I, Skroza N, Michelini S, Mambrin A, Balduzzi V, Bernardini N, Marchesiello A, Tolino E, Volpe S, Maddalena P, Di Fraia M, Mangino G, Romeo G and Potenza C: BRAF inhibitors: Molecular targeting and immunomodulatory actions. Cancers (Basel) 12(7):1823, 2020. PMID: 32645969. DOI: $10.3390 /$ cancers 12071823

219 Cin H, Meyer C, Herr R, Janzarik WG, Lambert S, Jones DT, Jacob K, Benner A, Witt H, Remke M, Bender S, Falkenstein F,
Van Anh TN, Olbrich H, von Deimling A, Pekrun A, Kulozik AE, Gnekow A, Scheurlen W, Witt O, Omran H, Jabado N, Collins VP, Brummer T, Marschalek R, Lichter P, Korshunov A and Pfister SM: Oncogenic FAM131B-BRAF fusion resulting from $7 \mathrm{q} 34$ deletion comprises an alternative mechanism of MAPK pathway activation in pilocytic astrocytoma. Acta Neuropathol 121(6): 763-774, 2011. PMID: 21424530. DOI: 10.1007/s00401-011-0817-z

220 Roth JJ, Santi M, Pollock AN, Harding BN, Rorke-Adams LB, Tooke LS and Biegel JA: Chromosome band 7q34 deletions resulting in KIAA1549-BRAF and FAM131B-BRAF fusions in pediatric low-grade gliomas. Brain Pathol 25(2): 182-192, 2015. PMID: 25040262. DOI: 10.1111/bpa.12167

221 Busse TM, Roth JJ, Wilmoth D, Wainwright L, Tooke L and Biegel JA: Copy number alterations determined by single nucleotide polymorphism array testing in the clinical laboratory are indicative of gene fusions in pediatric cancer patients. Genes Chromosomes Cancer 56(10): 730-749, 2017. PMID: 28597942. DOI: $10.1002 / \mathrm{gcc} .22477$

222 Kokubo H, Lun Y and Johnson RL: Identification and expression of a novel family of bHLH cDNAs related to Drosophila hairy and enhancer of split. Biochem Biophys Res Commun 260(2): 459-465, 1999. PMID: 10403790. DOI: 10.1006/bbrc.1999.0880

223 Leimeister C, Externbrink A, Klamt B and Gessler M: Hey genes: A novel subfamily of hairy- and enhancer of split related genes specifically expressed during mouse embryogenesis. Mech Dev 85(1-2): 173-177, 1999. PMID: 10415358. DOI: 10.1016/ s0925-4773(99)00080-5

224 Chin MT, Maemura K, Fukumoto S, Jain MK, Layne MD, Watanabe M, Hsieh CM and Lee ME: Cardiovascular basic helix loop helix factor 1, a novel transcriptional repressor expressed preferentially in the developing and adult cardiovascular system. J Biol Chem 275(9): 6381-6387, 2000. PMID: 10692439. DOI: 10.1074/jbc.275.9.6381

225 Steidl C, Leimeister C, Klamt B, Maier M, Nanda I, Dixon M, Clarke R, Schmid M and Gessler M: Characterization of the human and mouse HEY1, HEY2, and HEYL genes: Cloning, mapping, and mutation screening of a new bHLH gene family. Genomics 66(2): 195-203, 2000. PMID: 10860664. DOI: 10.1006/geno.2000.6200

226 Voegel JJ, Heine MJ, Zechel C, Chambon P and Gronemeyer H: TIF2, a $160 \mathrm{kDa}$ transcriptional mediator for the liganddependent activation function AF-2 of nuclear receptors. EMBO J 15(14): 3667-3675, 1996. PMID: 8670870.

227 Hong H, Kohli K, Garabedian MJ and Stallcup MR: GRIP1, a transcriptional coactivator for the AF-2 transactivation domain of steroid, thyroid, retinoid, and vitamin D receptors. Mol Cell Biol 17(5): 2735-2744, 1997. PMID: 9111344. DOI: 10.1128/ mcb.17.5.2735

228 Carapeti M, Aguiar RC, Goldman JM and Cross NC: A novel fusion between MOZ and the nuclear receptor coactivator TIF2 in acute myeloid leukemia. Blood 91(9): 3127-3133, 1998. PMID: 9558366.

229 Liang J, Prouty L, Williams BJ, Dayton MA and Blanchard KL: Acute mixed lineage leukemia with an inv(8)(p11q13) resulting in fusion of the genes for MOZ and TIF2. Blood 92(6): 21182122, 1998. PMID: 9731070.

230 Nakayama R, Miura Y, Ogino J, Susa M, Watanabe I, Horiuchi $\mathrm{K}$, Anazawa U, Toyama Y, Morioka H, Mukai M and Hasegawa T: Detection of HEY1-NCOA2 fusion by fluorescence in-situ 
hybridization in formalin-fixed paraffin-embedded tissues as a possible diagnostic tool for mesenchymal chondrosarcoma. Pathol Int 62(12): 823-826, 2012. PMID: 23252872. DOI: $10.1111 /$ pin. 12022

231 Wang L, Motoi T, Khanin R, Olshen A, Mertens F, Bridge J, Dal Cin P, Antonescu CR, Singer S, Hameed M, Bovee JV, Hogendoorn PC, Socci N and Ladanyi M: Identification of a novel, recurrent HEY1-NCOA2 fusion in mesenchymal chondrosarcoma based on a genome-wide screen of exon-level expression data. Genes Chromosomes Cancer 51(2): 127-139, 2012. PMID: 22034177. DOI: $10.1002 / \mathrm{gcc} .20937$

232 Andersson C, Osterlundh G, Enlund F, Kindblom LG and Hansson M: Primary spinal intradural mesenchymal chondrosarcoma with detection of fusion gene HEY1-NCOA2: A paediatric case report and review of the literature. Oncol Lett 8(4): 1608-1612, 2014. PMID: 25202377. DOI: 10.3892/ ol.2014.2364

233 Moriya K, Katayama S, Onuma M, Rikiishi T, Hosaka M, Watanabe M, Hasegawa T, Sasahara $\mathrm{Y}$ and Kure $\mathrm{S}$ : Mesenchymal chondrosarcoma diagnosed on FISH for HEY1NCOA2 fusion gene. Pediatr Int 56(5): e55-e57, 2014. PMID: 25336010. DOI: $10.1111 /$ ped.12407

234 Panagopoulos I, Gorunova L, Bjerkehagen B, Boye K and Heim S: Chromosome aberrations and HEY1-NCOA2 fusion gene in a mesenchymal chondrosarcoma. Oncol Rep 32(1): 40-44, 2014. PMID: 24839999. DOI: 10.3892/or.2014.3180

235 Cohen JN, Solomon DA, Horvai AE and Kakar S: Pancreatic involvement by mesenchymal chondrosarcoma harboring the HEY1-NCOA2 gene fusion. Hum Pathol 58: 35-40, 2016. PMID: 27544802. DOI: 10.1016/j.humpath.2016.07.026

236 Toki S, Motoi T, Miyake M, Kobayashi E, Kawai A and Yoshida A: Minute mesenchymal chondrosarcoma within osteochondroma: An unexpected diagnosis confirmed by HEY1NCOA2 fusion. Hum Pathol 81: 255-260, 2018. PMID: 29596896. DOI: 10.1016/j.humpath.2018.03.014

237 Kas K, Voz ML, Röijer E, Aström AK, Meyen E, Stenman G and Van de Ven WJ: Promoter swapping between the genes for a novel zinc finger protein and beta-catenin in pleiomorphic adenomas with $\mathrm{t}(3 ; 8)(\mathrm{p} 21 ; \mathrm{q} 12)$ translocations. Nat Genet $15(2)$ : 170-174, 1997. PMID: 9020842. DOI: 10.1038/ng0297-170

238 Kas K, Voz ML, Hensen K, Meyen E and Van de Ven WJ: Transcriptional activation capacity of the novel PLAG family of zinc finger proteins. J Biol Chem 273(36): 23026-23032, 1998. PMID: 9722527. DOI: 10.1074/jbc.273.36.23026

239 Van Dyck F, Declercq J, Braem CV and Van de Ven WJ: PLAG1, the prototype of the PLAG gene family: Versatility in tumour development (review). Int J Oncol 30(4): 765-774, 2007. PMID: 17332914.

240 Juma AR, Damdimopoulou PE, Grommen SV, Van de Ven WJ and De Groef B: Emerging role of PLAG1 as a regulator of growth and reproduction. J Endocrinol 228(2): R45-R56, 2016. PMID: 26577933. DOI: 10.1530/JOE-15-0449

241 Kas K, Röijer E, Voz M, Meyen E, Stenman G and Van de Ven WJ: A 2-Mb YAC contig and physical map covering the chromosome 8q12 breakpoint cluster region in pleomorphic adenomas of the salivary glands. Genomics 43(3): 349-358, 1997. PMID: 9268638. DOI: 10.1006/geno.1997.4819

242 Voz ML, Aström AK, Kas K, Mark J, Stenman G and Van de Ven WJ: The recurrent translocation $\mathrm{t}(5 ; 8)(\mathrm{p} 13 ; \mathrm{q} 12)$ in pleomorphic adenomas results in upregulation of PLAG1 gene expression under control of the LIFR promoter. Oncogene 16(11): 14091416, 1998. PMID: 9525740. DOI: 10.1038/sj.onc.1201660

243 Aström AK, Voz ML, Kas K, Röijer E, Wedell B, Mandahl N, Van de Ven W, Mark J and Stenman G: Conserved mechanism of PLAG1 activation in salivary gland tumors with and without chromosome 8q12 abnormalities: Identification of SII as a new fusion partner gene. Cancer Res 59(4): 918-923, 1999. PMID: 10029085.

244 Hibbard MK, Kozakewich HP, Dal Cin P, Sciot R, Tan X, Xiao $\mathrm{S}$ and Fletcher JA: PLAG1 fusion oncogenes in lipoblastoma. Cancer Res 60(17): 4869-4872, 2000. PMID: 10987300.

245 Persson F, Winnes M, Andrén Y, Wedell B, Dahlenfors R, Asp J, Mark J, Enlund F and Stenman G: High-resolution array CGH analysis of salivary gland tumors reveals fusion and amplification of the FGFR1 and PLAG1 genes in ring chromosomes. Oncogene 27(21): 3072-3080, 2008. PMID: 18059337. DOI: 10.1038/sj.onc.1210961

246 Yoshida H, Miyachi M, Ouchi K, Kuwahara Y, Tsuchiya K, Iehara T, Konishi E, Yanagisawa A and Hosoi H: Identification of COL3A1 and RAB2A as novel translocation partner genes of PLAG1 in lipoblastoma. Genes Chromosomes Cancer 53(7): 606-611, 2014. PMID: 24700772. DOI: 10.1002/gcc.22170

247 Voz ML, Agten NS, Van de Ven WJ and Kas K: PLAG1, the main translocation target in pleomorphic adenoma of the salivary glands, is a positive regulator of IGF-II. Cancer Res 60(1): 106113, 2000. PMID: 10646861

248 Voz ML, Mathys J, Hensen K, Pendeville H, Van Valckenborgh I, Van Huffel C, Chavez M, Van Damme B, De Moor B, Moreau $\mathrm{Y}$ and Van de Ven WJ: Microarray screening for target genes of the proto-oncogene PLAG1. Oncogene 23(1): 179-191, 2004. PMID: 14712223. DOI: 10.1038/sj.onc.1207013

249 Declercq J, Van Dyck F, Braem CV, Van Valckenborgh IC, Voz M, Wassef M, Schoonjans L, Van Damme B, Fiette L and Van de Ven WJ: Salivary gland tumors in transgenic mice with targeted PLAG1 proto-oncogene overexpression. Cancer Res 65(11): 4544-4553, 2005. PMID: 15930271. DOI: 10.1158/00085472.CAN-04-4041

250 Declercq J, Van Dyck F, Van Damme B and Van de Ven WJ: Upregulation of Igf and Wnt signalling associated genes in pleomorphic adenomas of the salivary glands in PLAG1 transgenic mice. Int J Oncol 32(5): 1041-1047, 2008. PMID: 18425330.

251 Wang Y, Shang W, Lei X, Shen S, Zhang H, Wang Z, Huang L, Yu Z, Ong H, Yin X, Yang W and Zhang C: Opposing functions of PLAG1 in pleomorphic adenoma: A microarray analysis of PLAG1 transgenic mice. Biotechnol Lett 35(9): 1377-1385, 2013. PMID: 23690029. DOI: 10.1007/s10529013-1213-7

252 Watanabe K and Yamaguchi Y: Molecular identification of a putative human hyaluronan synthase. J Biol Chem 271(38): 22945-22948, 1996. PMID: 8798477. DOI: 10.1074/jbc. 271.38.22945

253 Spicer AP, Seldin MF, Olsen AS, Brown N, Wells DE, Doggett NA, Itano $\mathrm{N}$, Kimata $\mathrm{K}$, Inazawa $\mathrm{J}$ and McDonald JA: Chromosomal localization of the human and mouse hyaluronan synthase genes. Genomics 41(3): 493-497, 1997. PMID: 9169154. DOI: 10.1006/geno.1997.4696

254 Monslow J, Williams JD, Norton N, Guy CA, Price IK, Coleman SL, Williams NM, Buckland PR, Spicer AP, Topley N, Davies M and Bowen T: The human hyaluronan synthase genes: genomic structures, proximal promoters and polymorphic microsatellite 
markers. Int J Biochem Cell Biol 35(8): 1272-1283, 2003. PMID: 12757764. DOI: $10.1016 / \mathrm{s} 1357-2725(03) 00048-7$

255 Passi A, Vigetti D, Buraschi S and Iozzo RV: Dissecting the role of hyaluronan synthases in the tumor microenvironment. FEBS J 286(15): 2937-2949, 2019. PMID: 30974514. DOI: $10.1111 /$ febs. 14847

256 Kobayashi T, Chanmee T and Itano N: Hyaluronan: Metabolism and function. Biomolecules 10(11):1525, 2020. PMID 33171800. DOI: 10.3390/biom10111525

257 Morerio C, Rapella A, Rosanda C, Tassano E, Gambini C, Romagnoli $G$ and Panarello $C$ : PLAG1-HAS2 fusion in lipoblastoma with masked $8 \mathrm{q}$ intrachromosomal rearrangement. Cancer Genet Cytogenet 156(2): 183-184, 2005. PMID: 15642402. DOI: $10.1016 / j$.cancergencyto.2004.04.017

258 Warren M, Turpin BK, Mark M, Smolarek TA and Li X: Undifferentiated myxoid lipoblastoma with PLAG1-HAS2 fusion in an infant; Morphologically mimicking primitive myxoid mesenchymal tumor of infancy (PMMTI)-diagnostic importance of cytogenetic and molecular testing and literature review. Cancer Genet 209(1-2): 21-29, 2016. PMID: 26701195. DOI: $10.1016 /$ j.cancergen.2015.11.004

259 Wang G, Guzman MA and Batanian JR: Three novel aberrations involving PLAG1 leading to lipoblastoma in three different patients: High amplification, partial deletion, and a unique complex rearrangement. Cytogenet Genome Res 159(2): 81-87, 2019. PMID: 31614359 . DOI: 10.1159/000503158

260 Gai Z, Gui T and Muragaki Y: The function of TRPS1 in the development and differentiation of bone, kidney, and hair follicles. Histol Histopathol 26(7): 915-921, 2011. PMID: 21630221. DOI: 10.14670/HH-26.915

261 Kokame K, Kato H and Miyata T: Homocysteine-respondent genes in vascular endothelial cells identified by differential display analysis. GRP78/BiP and novel genes. J Biol Chem 271(47): 29659-29665, 1996. PMID: 8939898. DOI: 10.1074/jbc.271.47.29659

262 van Belzen N, Dinjens WN, Diesveld MP, Groen NA, van der Made AC, Nozawa Y, Vlietstra R, Trapman J and Bosman FT: A novel gene which is up-regulated during colon epithelial cell differentiation and down-regulated in colorectal neoplasms. Lab Invest 77(1): 85-92, 1997. PMID: 9251681.

263 Zhou D, Salnikow K and Costa M: Cap43, a novel gene specifically induced by Ni2+ compounds. Cancer Res 58(10): 2182-2189, 1998. PMID: 9605764.

264 Kalaydjieva L, Gresham D, Gooding R, Heather L, Baas F, de Jonge R, Blechschmidt K, Angelicheva D, Chandler D, Worsley P, Rosenthal A, King RH and Thomas PK: N-myc downstreamregulated gene 1 is mutated in hereditary motor and sensory neuropathy-Lom. Am J Hum Genet 67(1): 47-58, 2000. PMID: 10831399. DOI: $10.1086 / 302978$

265 von Lindern M, Poustka A, Lerach H and Grosveld G: The $(6 ; 9)$ chromosome translocation, associated with a specific subtype of acute nonlymphocytic leukemia, leads to aberrant transcription of a target gene on 9q34. Mol Cell Biol 10(8): 4016-4026, 1990. PMID: 2370860. DOI: 10.1128/mcb.10.8.4016

266 von Lindern M, Breems D, van Baal S, Adriaansen H and Grosveld G: Characterization of the translocation breakpoint sequences of two DEK-CAN fusion genes present in $\mathrm{t}(6 ; 9)$ acute myeloid leukemia and a SET-CAN fusion gene found in a case of acute undifferentiated leukemia. Genes Chromosomes Cancer 5(3): 227234, 1992. PMID: 1384675. DOI: 10.1002/gcc.2870050309
267 von Lindern M, van Baal S, Wiegant J, Raap A, Hagemeijer A and Grosveld G: Can, a putative oncogene associated with myeloid leukemogenesis, may be activated by fusion of its 3' half to different genes: Characterization of the set gene. Mol Cell Biol 12(8): 3346-3355, 1992. PMID: 1630450. DOI: 10.1128/ mcb.12.8.3346

268 Seo SB, McNamara P, Heo S, Turner A, Lane WS and Chakravarti D: Regulation of histone acetylation and transcription by INHAT, a human cellular complex containing the set oncoprotein. Cell 104(1): 119-130, 2001. PMID: 11163245. DOI: 10.1016/s0092-8674(01)00196-9

269 Cervoni N, Detich N, Seo SB, Chakravarti D and Szyf M: The oncoprotein Set/TAF-1beta, an inhibitor of histone acetyltransferase, inhibits active demethylation of DNA, integrating DNA methylation and transcriptional silencing. J Biol Chem 277(28): 25026-25031, 2002. PMID: 11978794. DOI: $10.1074 /$ jbc.M202256200

270 Mendes A and Fahrenkrog B: NUP214 in Leukemia: It's more than transport. Cells 8(1):76, 2019. PMID: 30669574. DOI: 10.3390/cells 8010076

271 Saito S, Miyaji-Yamaguchi $M$ and Nagata K: Aberrant intracellular localization of SET-CAN fusion protein, associated with a leukemia, disorganizes nuclear export. Int J Cancer 111(4): 501-507, 2004. PMID: 15239126. DOI: 10.1002/ijc.20296

272 Oka M, Mura S, Otani M, Miyamoto Y, Nogami J, Maehara K, Harada A, Tachibana T, Yoneda Y and Ohkawa Y: Chromatinbound CRM1 recruits SET-Nup214 and NPM1c onto HOX clusters causing aberrant $H O X$ expression in leukemia cells. Elife 8: e46667, 2019. PMID: 31755865. DOI: 10.7554/eLife.46667

273 Saito S, Nouno K, Shimizu R, Yamamoto M and Nagata K: Impairment of erythroid and megakaryocytic differentiation by a leukemia-associated and $\mathrm{t}(9 ; 9)$-derived fusion gene product, SET/TAF-Ibeta-CAN/Nup214. J Cell Physiol 214(2): 322-333, 2008. PMID: 17620317. DOI: 10.1002/jcp.21199

274 Rosati R, La Starza R, Barba G, Gorello P, Pierini V, Matteucci C, Roti G, Crescenzi B, Aloisi T, Aversa F, Martelli MF and Mecucci C: Cryptic chromosome 9q34 deletion generates TAFIalpha/CAN and TAF-Ibeta/CAN fusion transcripts in acute myeloid leukemia. Haematologica 92(2): 232-235, 2007. PMID: 17296573. DOI: $10.3324 /$ haematol.10538

275 Van Vlierberghe P, van Grotel M, Tchinda J, Lee C, Beverloo HB, van der Spek PJ, Stubbs A, Cools J, Nagata K, Fornerod M, Buijs-Gladdines J, Horstmann M, van Wering ER, Soulier J, Pieters R and Meijerink JP: The recurrent SET-NUP214 fusion as a new HOXA activation mechanism in pediatric T-cell acute lymphoblastic leukemia. Blood 111(9): 4668-4680, 2008. PMID: 18299449. DOI: 10.1182/blood-2007-09-111872

276 Quentmeier H, Schneider B, Röhrs S, Romani J, Zaborski M, Macleod RA and Drexler HG: SET-NUP214 fusion in acute myeloid leukemia- and T-cell acute lymphoblastic leukemiaderived cell lines. J Hematol Oncol 2: 3, 2009. PMID: 19166587. DOI: $10.1186 / 1756-8722-2-3$

277 Gorello P, La Starza R, Varasano E, Chiaretti S, Elia L, Pierini V, Barba G, Brandimarte L, Crescenzi B, Vitale A, Messina M, Grammatico S, Mancini M, Matteucci C, Bardi A, Guarini A, Martelli MF, Foà $\mathrm{R}$ and Mecucci C: Combined interphase fluorescence in situ hybridization elucidates the genetic heterogeneity of T-cell acute lymphoblastic leukemia in adults. Haematologica 95(1): 79-86, 2010. PMID: 20065082. DOI: 10.3324/haematol.2009.010413 
278 Kim J, Lee SG, Song J, Kim SJ, Rha SY, Lee KA, Park TS and Choi JR: Molecular characterization of alternative SET-NUP214 fusion transcripts in a case of acute undifferentiated leukemia. Cancer Genet Cytogenet 201(2): 73-80, 2010. PMID: 20682390. DOI: $10.1016 / j$.cancergencyto.2010.05.010

279 Zhu HH, Zhao XS, Qin YZ, Lai YY and Jiang H: B-cell acute lymphoblastic leukemia associated with SET-NUP214 rearrangement: A case report and review of the literature. Oncol Lett 11(4): 2644-2650, 2016. PMID: 27073532. DOI: 10.3892/ol.2016.4260

280 Papenhausen P, Kelly CA, Zhang Z, Tepperberg J, Burnside RD and Schwartz S: Multidisciplinary analysis of pediatric T-ALL: 9q34 gene fusions. Cancer Genet 231-232: 1-13, 2019. PMID: 30803551. DOI: 10.1016/j.cancergen.2018.12.002

281 Zhang H, Zhang L, Li Y, Gu H and Wang X: SET-CAN fusion gene in acute leukemia and myeloid neoplasms: Report of three cases and a literature review. Onco Targets Ther 13: 7665-7681, 2020. PMID: 32821125. DOI: 10.2147/OTT.S258365

282 Chen B, Jiang L, Zhong ML, Li JF, Li BS, Peng LJ, Dai YT, Cui BW, Yan TQ, Zhang WN, Weng XQ, Xie YY, Lu J, Ren RB, Chen SN, Hu JD, Wu DP, Chen Z, Tang JY, Huang JY, Mi JQ and Chen SJ: Identification of fusion genes and characterization of transcriptome features in T-cell acute lymphoblastic leukemia. Proc Natl Acad Sci USA 115(2): 373-378, 2018. PMID: 29279377. DOI: 10.1073/pnas.1717125115

283 Gao MG, Hong Y, Qin YZ, Chang YJ, Wang Y, Zhang XH, Xu LP, Huang XJ and Zhao XS: Prognostic significance of SETNUP214 fusion gene in acute leukemia after allogeneic hematopoietic stem cell transplantation. Medicine (Baltimore) 99(50): e23569, 2020. PMID: 33327316. DOI: 10.1097/ MD.0000000000023569

284 Bass AJ, Lawrence MS, Brace LE, Ramos AH, Drier Y, Cibulskis K, Sougnez C, Voet D, Saksena G, Sivachenko A, Jing R, Parkin M, Pugh T, Verhaak RG, Stransky N, Boutin AT, Barretina J, Solit DB, Vakiani E, Shao W, Mishina Y, Warmuth M, Jimenez J, Chiang DY, Signoretti S, Kaelin WG Jr, Spardy N, Hahn WC, Hoshida Y, Ogino S, DePinho RA, Chin L, Garraway LA, Fuchs CS, Baselga J, Tabernero J, Gabriel S, Lander ES, Getz G and Meyerson M: Genomic sequencing of colorectal adenocarcinomas identifies a recurrent VTI1A-TCF7L2 fusion. Nat Genet 43(10): 964-968, 2011. PMID: 21892161. DOI: 10.1038/ng.936

285 Xu Y, Wong SH, Tang BL, Subramaniam VN, Zhang T and Hong W: A 29-kilodalton golgi soluble N-ethylmaleimide-sensitive factor attachment protein receptor (Vti1-rp2) implicated in protein trafficking in the secretory pathway. J Biol Chem 273(34): 21783-21789, 1998. PMID: 9705316. DOI: 10.1074/ jbc. 273.34 .21783

286 Flowerdew SE and Burgoyne RD: A VAMP7/Vtila SNARE complex distinguishes a non-conventional traffic route to the cell surface used by KChIP1 and Kv4 potassium channels. Biochem J 418(3): 529-540, 2009. PMID: 19138172. DOI: 10.1042/ BJ20081736

$287 \mathrm{Jin} \mathrm{T}$ : Current understanding on role of the Wnt signaling pathway effector TCF7L2 in glucose homeostasis. Endocr Rev 37(3): 254-277, 2016. PMID: 27159876. DOI: 10.1210/er.20151146

288 Bem J, Brożko N, Chakraborty C, Lipiec MA, Koziński K, Nagalski A, Szewczyk ŁM and Wiśniewska MB: Wnt/ß-catenin signaling in brain development and mental disorders: Keeping
TCF7L2 in mind. FEBS Lett 593(13): 1654-1674, 2019. PMID: 31218672. DOI: $10.1002 / 1873-3468.13502$

289 Prokunina-Olsson L, Welch C, Hansson O, Adhikari N, Scott LJ, Usher N, Tong M, Sprau A, Swift A, Bonnycastle LL, Erdos MR, He Z, Saxena R, Harmon B, Kotova O, Hoffman EP, Altshuler D, Groop L, Boehnke M, Collins FS and Hall JL: Tissue-specific alternative splicing of TCF7L2. Hum Mol Genet 18(20): 37953804, 2009. PMID: 19602480. DOI: 10.1093/hmg/ddp321

290 Nome T, Hoff AM, Bakken AC, Rognum TO, Nesbakken A and Skotheim RI: High frequency of fusion transcripts involving TCF7L2 in colorectal cancer: Novel fusion partner and splice variants. PLoS One 9(3): e91264, 2014. PMID: 24608966. DOI: 10.1371/journal.pone.0091264

291 Davidsen J, Larsen S, Coskun M, Gögenur I, Dahlgaard K, Bennett EP and Troelsen JT: The VTI1A-TCF4 colon cancer fusion protein is a dominant negative regulator of Wnt signaling and is transcriptionally regulated by intestinal homeodomain factor CDX2. PLoS One 13(7): e0200215, 2018. PMID: 29975781. DOI: 10.1371/journal.pone.0200215

292 Caslini C, Yang Z, El-Osta M, Milne TA, Slany RK and Hess JL: Interaction of MLL amino terminal sequences with menin is required for transformation. Cancer Res 67(15): 7275-7283, 2007. PMID: 17671196. DOI: 10.1158/0008-5472.CAN-06-2369

293 Cosgrove MS and Patel A: Mixed lineage leukemia: A structurefunction perspective of the MLL1 protein. FEBS J 277(8): 18321842, 2010. PMID: 20236310. DOI: 10.1111/j.17424658.2010.07609.x

294 Grembecka J, Belcher AM, Hartley T and Cierpicki T: Molecular basis of the mixed lineage leukemia-menin interaction: Implications for targeting mixed lineage leukemias. J Biol Chem 285(52): 40690-40698, 2010. PMID: 20961854. DOI: 10.1074/jbc.M110.172783

295 Marschalek R: Mechanisms of leukemogenesis by MLL fusion proteins. Br J Haematol 152(2): 141-154, 2011. PMID: 21118195. DOI: 10.1111/j.1365-2141.2010.08459.x

296 Muntean AG: Mechanisms of mixed-lineage leukemia. Int J Hematol Oncol 2(3): 207-217, 2013. PMID: 24563734. DOI: 10.2217/ijh.13.20

297 Marschalek R: Systematic classification of mixed-lineage leukemia fusion partners predicts additional cancer pathways. Ann Lab Med 36(2): 85-100, 2016. PMID: 26709255. DOI: 10.3343/alm.2016.36.2.85

298 Fu JF, Hsu JJ, Tang TC and Shih LY: Identification of CBL, a proto-oncogene at 11q23.3, as a novel MLL fusion partner in a patient with de novo acute myeloid leukemia. Genes Chromosomes Cancer 37(2): 214-219, 2003. PMID: 12696071. DOI: $10.1002 / \mathrm{gcc} .10204$

299 Meyer C, Hofmann J, Burmeister T, Gröger D, Park TS, Emerenciano M, Pombo de Oliveira M, Renneville A, Villarese P, Macintyre E, Cavé H, Clappier E, Mass-Malo K, Zuna J, Trka J, De Braekeleer E, De Braekeleer M, Oh SH, Tsaur G, Fechina L, van der Velden VH, van Dongen JJ, Delabesse E, Binato R, Silva ML, Kustanovich A, Aleinikova O, Harris MH, Lund-Aho T, Juvonen V, Heidenreich O, Vormoor J, Choi WW, Jarosova M, Kolenova A, Bueno C, Menendez P, Wehner S, Eckert C, Talmant P, Tondeur S, Lippert E, Launay E, Henry C, Ballerini $\mathrm{P}$, Lapillone H, Callanan MB, Cayuela JM, Herbaux C, Cazzaniga G, Kakadiya PM, Bohlander S, Ahlmann M, Choi JR, Gameiro P, Lee DS, Krauter J, Cornillet-Lefebvre P, Te Kronnie G, Schäfer BW, Kubetzko S, Alonso CN, zur Stadt U, Sutton R, 
Venn NC, Izraeli S, Trakhtenbrot L, Madsen HO, Archer P, Hancock J, Cerveira N, Teixeira MR, Lo Nigro L, Möricke A, Stanulla M, Schrappe M, Sedék L, Szczepański T, Zwaan CM, Coenen EA, van den Heuvel-Eibrink MM, Strehl S, Dworzak M, Panzer-Grümayer R, Dingermann $\mathrm{T}$, Klingebiel $\mathrm{T}$ and Marschalek R: The MLL recombinome of acute leukemias in 2013. Leukemia 27(11): 2165-2176, 2013. PMID: 23628958. DOI: $10.1038 /$ leu.2013.135

300 Meyer C, Burmeister T, Gröger D, Tsaur G, Fechina L, Renneville A, Sutton R, Venn NC, Emerenciano M, Pombo-deOliveira MS, Barbieri Blunck C, Almeida Lopes B, Zuna J, Trka J, Ballerini P, Lapillonne H, De Braekeleer M, Cazzaniga G, Corral Abascal L, van der Velden VHJ, Delabesse E, Park TS, Oh SH, Silva MLM, Lund-Aho T, Juvonen V, Moore AS, Heidenreich O, Vormoor J, Zerkalenkova E, Olshanskaya Y, Bueno C, Menendez P, Teigler-Schlegel A, Zur Stadt U, Lentes J, Göhring G, Kustanovich A, Aleinikova O, Schäfer BW, Kubetzko S, Madsen HO, Gruhn B, Duarte X, Gameiro P, Lippert E, Bidet A, Cayuela JM, Clappier E, Alonso CN, Zwaan $\mathrm{CM}$, van den Heuvel-Eibrink MM, Izraeli S, Trakhtenbrot L, Archer P, Hancock J, Möricke A, Alten J, Schrappe M, Stanulla M, Strehl S, Attarbaschi A, Dworzak M, Haas OA, PanzerGrümayer R, Sedék L, Szczepański T, Caye A, Suarez L, Cavé $\mathrm{H}$ and Marschalek R: The MLL recombinome of acute leukemias in 2017. Leukemia 32(2): 273-284, 2018. PMID: 28701730. DOI: $10.1038 /$ leu.2017.213

301 Kourlas PJ, Strout MP, Becknell B, Veronese ML, Croce CM, Theil KS, Krahe R, Ruutu T, Knuutila S, Bloomfield CD and Caligiuri MA: Identification of a gene at 11q23 encoding a guanine nucleotide exchange factor: Evidence for its fusion with MLL in acute myeloid leukemia. Proc Natl Acad Sci USA 97(5): 2145-2150, 2000. PMID: 10681437. DOI: 10.1073/pnas.040569197

302 Shih LY, Liang DC, Fu JF, Wu JH, Wang PN, Lin TL, Dunn P, Kuo MC, Tang TC, Lin TH and Lai CL: Characterization of fusion partner genes in 114 patients with de novo acute myeloid leukemia and MLL rearrangement. Leukemia 20(2): 218-223, 2006. PMID: 16341046. DOI: 10.1038/sj.leu.2404024

303 Sevov M, Bunikis I, Häggqvist S, Höglund M, Rosenquist R, Ameur A and Cavelier L: Targeted RNA sequencing assay efficiently identifies Cryptic KMT2A (MLL)-fusions in acute leukemia patients. Blood 124(21): 2406-2406, 2019. DOI: 10.1182/blood.V124.21.2406.2406

304 Jung HS, Lin F, Wolpaw A, Reilly AF, Margolskee E, Luo M, Wertheim GB and Li MM: A novel KMT2A-ARHGEF12 fusion gene identified in a high-grade B-cell lymphoma. Cancer Genet 246-247: 41-43, 2020. PMID: 32805689. DOI: 10.1016/ j.cancergen.2020.08.003

305 Panagopoulos I, Andersen K, Eilert-Olsen M, Zeller B, MuntheKaas MC, Buechner J, Osnes LTN, Micci F and Heim S: Therapy-induced deletion in 11q23 leading to fusion of $K M T 2 A$ With ARHGEF12 and development of $\mathrm{B}$ lineage acute lymphoplastic leukemia in a child treated for acute myeloid leukemia Caused by $\mathrm{t}(9 ; 11)(\mathrm{p} 21 ; \mathrm{q} 23) /$ KMT2A-MLLT3. Cancer Genomics Proteomics 18(1): 67-81, 2021. PMID: 33419897. DOI: $10.21873 / \mathrm{cgp} .20242$

306 Meyer C, Schneider B, Reichel M, Angermueller S, Strehl S, Schnittger S, Schoch C, Jansen MW, van Dongen JJ, Pieters R, Haas OA, Dingermann T, Klingebiel $\mathrm{T}$ and Marschalek R: Diagnostic tool for the identification of MLL rearrangements including unknown partner genes. Proc Natl Acad Sci USA 102(2): 449-454, 2005. PMID: 15626757. DOI: 10.1073/pnas.0406994102

307 Katoh M and Katoh M: Identification and characterization of human FOXN5 and rat Foxn5 genes in silico. Int J Oncol 24(5): 1339-1344, 2004. PMID: 15067358.

308 Petit FG, Kervarrec C, Jamin SP, Smagulova F, Hao C, Becker E, Jégou B, Chalmel $\mathrm{F}$ and Primig M: Combining RNA and protein profiling data with network interactions identifies genes associated with spermatogenesis in mouse and human. Biol Reprod 92(3): 71, 2015. PMID: 25609838. DOI: 10.1095/ biolreprod.114.126250

309 Santo EE, Ebus ME, Koster J, Schulte JH, Lakeman A, van Sluis P, Vermeulen J, Gisselsson D, Øra I, Lindner S, Buckley PG, Stallings RL, Vandesompele J, Eggert A, Caron HN, Versteeg R and Molenaar JJ: Oncogenic activation of FOXR1 by 11q23 intrachromosomal deletion-fusions in neuroblastoma. Oncogene 31(12): 1571-1581, 2012. PMID: 21860421. DOI: 10.1038/onc. 2011.344

310 Honeyman JN, Simon EP, Robine N, Chiaroni-Clarke R, Darcy DG, Lim II, Gleason CE, Murphy JM, Rosenberg BR, Teegan L, Takacs CN, Botero S, Belote R, Germer S, Emde AK, Vacic V, Bhanot U, LaQuaglia MP and Simon SM: Detection of a recurrent DNAJB1-PRKACA chimeric transcript in fibrolamellar hepatocellular carcinoma. Science 343(6174): 1010-1014, 2014. PMID: 24578576. DOI: 10.1126/science. 1249484

311 Cornella H, Alsinet C, Sayols S, Zhang Z, Hao K, Cabellos L, Hoshida Y, Villanueva A, Thung S, Ward SC, Rodriguez-Carunchio L, Vila-Casadesús M, Imbeaud S, Lachenmayer A, Quaglia A, Nagorney DM, Minguez B, Carrilho F, Roberts LR, Waxman S, Mazzaferro V, Schwartz M, Esteller M, Heaton ND, Zucman-Rossi $\mathrm{J}$ and Llovet JM: Unique genomic profile of fibrolamellar hepatocellular carcinoma. Gastroenterology 148(4): 806-18.e10, 2015. PMID: 25557953. DOI: 10.1053/j.gastro.2014.12.028

312 Darcy DG, Chiaroni-Clarke R, Murphy JM, Honeyman JN, Bhanot U, LaQuaglia MP and Simon SM: The genomic landscape of fibrolamellar hepatocellular carcinoma: Whole genome sequencing of ten patients. Oncotarget 6(2): 755-770, 2015. PMID: 25605237. DOI: 10.18632/oncotarget.2712

313 Graham RP, Jin L, Knutson DL, Kloft-Nelson SM, Greipp PT, Waldburger N, Roessler S, Longerich T, Roberts LR, Oliveira AM, Halling KC, Schirmacher P and Torbenson MS: DNAJB1PRKACA is specific for fibrolamellar carcinoma. Mod Pathol 28(6): 822-829, 2015. PMID: 25698061. DOI: 10.1038/ modpathol.2015.4

314 Simon EP, Freije CA, Farber BA, Lalazar G, Darcy DG, Honeyman JN, Chiaroni-Clarke R, Dill BD, Molina H, Bhanot UK, La Quaglia MP, Rosenberg BR and Simon SM: Transcriptomic characterization of fibrolamellar hepatocellular carcinoma. Proc Natl Acad Sci USA 112(44): E5916-E5925, 2015. PMID: 26489647. DOI: 10.1073/pnas.1424894112

315 Xu L, Hazard FK, Zmoos AF, Jahchan N, Chaib H, Garfin PM, Rangaswami A, Snyder MP and Sage J: Genomic analysis of fibrolamellar hepatocellular carcinoma. Hum Mol Genet 24(1): 50-63, 2015. PMID: 25122662. DOI: $10.1093 / \mathrm{hmg} / \mathrm{ddu} 418$

316 Dinh TA, Vitucci EC, Wauthier E, Graham RP, Pitman WA, Oikawa T, Chen M, Silva GO, Greene KG, Torbenson MS, Reid LM and Sethupathy P: Comprehensive analysis of the cancer genome atlas reveals a unique gene and non-coding RNA signature of fibrolamellar carcinoma. Sci Rep 7: 44653, 2017. PMID: 28304380. DOI: $10.1038 /$ srep44653 
317 Singhi AD, Wood LD, Parks E, Torbenson MS, Felsenstein M, Hruban RH, Nikiforova MN, Wald AI, Kaya C, Nikiforov YE, Favazza L, He J, McGrath K, Fasanella KE, Brand RE, Lennon AM, Furlan A, Dasyam AK, Zureikat AH, Zeh HJ, Lee K, Bartlett DL and Slivka A: Recurrent rearrangements in PRKACA and PRKACB in intraductal oncocytic papillary neoplasms of the pancreas and bile duct. Gastroenterology 158(3): 573-582.e2, 2020. PMID: 31678302. DOI: 10.1053/ j.gastro.2019.10.028

318 Vyas M, Hechtman JF, Zhang Y, Benayed R, Yavas A, Askan G, Shia J, Klimstra DS and Basturk O: DNAJB1-PRKACA fusions occur in oncocytic pancreatic and biliary neoplasms and are not specific for fibrolamellar hepatocellular carcinoma. Mod Pathol 33(4): 648-656, 2020. PMID: 31676785. DOI: 10.1038/s41379019-0398-2

319 Qiu XB, Shao YM, Miao S and Wang L: The diversity of the DnaJ/Hsp40 family, the crucial partners for Hsp70 chaperones. Cell Mol Life Sci 63(22): 2560-2570, 2006. PMID: 16952052. DOI: $10.1007 / \mathrm{s} 00018-006-6192-6$

320 Liu Q, Liang C and Zhou L: Structural and functional analysis of the Hsp70/Hsp40 chaperone system. Protein Sci 29(2): 378390, 2020. PMID: 31509306. DOI: 10.1002/pro.3725

321 Turnham RE and Scott JD: Protein kinase A catalytic subunit isoform PRKACA; History, function and physiology. Gene 577(2): 101-108, 2016. PMID: 26687711. DOI: 10.1016/ j.gene.2015.11.052

322 Søberg K, Moen LV, Skålhegg BS and Laerdahl JK: Evolution of the cAMP-dependent protein kinase (PKA) catalytic subunit isoforms. PLoS One 12(7): e0181091, 2017. PMID: 28742821. DOI: 10.1371 /journal.pone.0181091

323 Engelholm LH, Riaz A, Serra D, Dagnæs-Hansen F, Johansen JV, Santoni-Rugiu E, Hansen SH, Niola $\mathrm{F}$ and Frödin M: CRISPR/Cas9 engineering of adult mouse liver demonstrates that the Dnajb1-Prkaca gene fusion is sufficient to induce tumors resembling fibrolamellar hepatocellular carcinoma. Gastroenterology 153(6): 1662-1673.e10, 2017. PMID: 28923495. DOI: $10.1053 /$ j.gastro.2017.09.008

324 Kastenhuber ER, Lalazar G, Houlihan SL, Tschaharganeh DF, Baslan T, Chen CC, Requena D, Tian S, Bosbach B, Wilkinson JE, Simon SM and Lowe SW: DNAJB1-PRKACA fusion kinase interacts with $\beta$-catenin and the liver regenerative response to drive fibrolamellar hepatocellular carcinoma. Proc Natl Acad Sci USA 114(50): 13076-13084, 2017. PMID: 29162699. DOI: $10.1073 /$ pnas. 1716483114

325 Tomlins SA, Rhodes DR, Perner S, Dhanasekaran SM, Mehra R, Sun XW, Varambally S, Cao X, Tchinda J, Kuefer R, Lee C, Montie JE, Shah RB, Pienta KJ, Rubin MA and Chinnaiyan AM: Recurrent fusion of TMPRSS2 and ETS transcription factor genes in prostate cancer. Science 310(5748): 644-648, 2005. PMID: 16254181. DOI: 10.1126/science.1117679

326 Cerveira N, Ribeiro FR, Peixoto A, Costa V, Henrique R, Jerónimo $\mathrm{C}$ and Teixeira MR: TMPRSS2-ERG gene fusion causing ERG overexpression precedes chromosome copy number changes in prostate carcinomas and paired HGPIN lesions. Neoplasia 8(10): 826-832, 2006. PMID: 17032499. DOI: $10.1593 /$ neo.06427

327 Hermans KG, van Marion R, van Dekken H, Jenster G, van Weerden WM and Trapman J: TMPRSS2:ERG fusion by translocation or interstitial deletion is highly relevant in androgen-dependent prostate cancer, but is bypassed in late-stage androgen receptor-negative prostate cancer. Cancer Res 66(22): 10658-10663, 2006. PMID: 17108102. DOI: 10.1158/00085472.CAN-06-1871

328 Soller MJ, Isaksson M, Elfving P, Soller W, Lundgren R and Panagopoulos I: Confirmation of the high frequency of the TMPRSS2/ERG fusion gene in prostate cancer. Genes Chromosomes Cancer 45(7): 717-719, 2006. PMID: 16575875. DOI: $10.1002 / \mathrm{gcc} .20329$

329 Yoshimoto M, Joshua AM, Chilton-Macneill S, Bayani J, Selvarajah S, Evans AJ, Zielenska M and Squire JA: Three-color FISH analysis of TMPRSS2/ERG fusions in prostate cancer indicates that genomic microdeletion of chromosome 21 is associated with rearrangement. Neoplasia 8(6): 465-469, 2006. PMID: 16820092. DOI: 10.1593/neo.06283

330 Lapointe J, Kim YH, Miller MA, Li C, Kaygusuz G, van de Rijn M, Huntsman DG, Brooks JD and Pollack JR: A variant TMPRSS2 isoform and ERG fusion product in prostate cancer with implications for molecular diagnosis. Mod Pathol 20(4): 467-473, 2007. PMID: 17334351. DOI: 10.1038/modpathol. 3800759

331 Mosquera JM, Perner S, Genega EM, Sanda M, Hofer MD, Mertz KD, Paris PL, Simko J, Bismar TA, Ayala G, Shah RB, Loda M and Rubin MA: Characterization of TMPRSS2-ERG fusion high-grade prostatic intraepithelial neoplasia and potential clinical implications. Clin Cancer Res 14(11): 33803385, 2008. PMID: 18519767. DOI: 10.1158/1078-0432.CCR07-5194

332 Paoloni-Giacobino A, Chen H, Peitsch MC, Rossier C and Antonarakis SE: Cloning of the TMPRSS2 gene, which encodes a novel serine protease with transmembrane, LDLRA, and SRCR domains and maps to 21q22.3. Genomics 44(3): 309-320, 1997. PMID: 9325052. DOI: 10.1006/geno.1997.4845

333 Bugge TH, Antalis TM and Wu Q: Type II transmembrane serine proteases. J Biol Chem 284(35): 23177-23181, 2009. PMID: 19487698. DOI: $10.1074 /$ jbc.R109.021006

334 Tanabe LM and List K: The role of type II transmembrane serine protease-mediated signaling in cancer. FEBS J 284(10): 14211436, 2017. PMID: 27870503. DOI: 10.1111/febs.13971

335 Wang Q, Li W, Liu XS, Carroll JS, Jänne OA, Keeton EK, Chinnaiyan AM, Pienta KJ and Brown M: A hierarchical network of transcription factors governs androgen receptor-dependent prostate cancer growth. Mol Cell 27(3): 380-392, 2007. PMID: 17679089. DOI: $10.1016 /$ j.molcel.2007.05.041

336 Clinckemalie L, Spans L, Dubois V, Laurent M, Helsen C, Joniau $\mathrm{S}$ and Claessens F: Androgen regulation of the TMPRSS2 gene and the effect of a SNP in an androgen response element. Mol Endocrinol 27(12): 2028-2040, 2013. PMID: 24109594. DOI: 10.1210/me.2013-1098

337 Reddy ES, Rao VN and Papas TS: The erg gene: A human gene related to the ets oncogene. Proc Natl Acad Sci USA 84(17): 6131-6135, 1987. PMID: 3476934. DOI: 10.1073/ pnas.84.17.6131

338 Rao VN, Modi WS, Drabkin HD, Patterson D, O’Brien SJ, Papas TS and Reddy ES: The human erg gene maps to chromosome 21, band q22: Relationship to the $8 ; 21$ translocation of acute myelogenous leukemia. Oncogene 3(5): 497-500, 1988. PMID: 3274086 .

339 Adamo P and Ladomery MR: The oncogene ERG: A key factor in prostate cancer. Oncogene 35(4): 403-414, 2016. PMID: 25915839. DOI: 10.1038/onc.2015.109 
340 Tu JJ, Rohan S, Kao J, Kitabayashi N, Mathew S and Chen YT: Gene fusions between TMPRSS2 and ETS family genes in prostate cancer: Frequency and transcript variant analysis by RT-PCR and FISH on paraffin-embedded tissues. Mod Pathol 20(9): 921-928, 2007. PMID: 17632455 . DOI: 10.1038/modpathol.3800903

341 Yoshimoto M, Ludkovski O, Bayani J, Graham C, Zielenska M and Squire JA: Microdeletion and concurrent translocation associated with a complex TMPRSS2:ERG prostate cancer gene fusion. Genes Chromosomes Cancer 46(9): 861-863, 2007. PMID: 17584912 . DOI: $10.1002 /$ gcc.20470

342 Teixeira MR: Chromosome mechanisms giving rise to the TMPRSS2-ERG fusion oncogene in prostate cancer and HGPIN lesions. Am J Surg Pathol 32(4): 642-4; author reply 644, 2008. PMID: 18317354. DOI: 10.1097/PAS.0b013e31815b6056

343 Ishkanian AS, Mallof CA, Ho J, Meng A, Albert M, Syed A, van der Kwast T, Milosevic M, Yoshimoto M, Squire JA, Lam WL and Bristow RG: High-resolution array CGH identifies novel regions of genomic alteration in intermediate-risk prostate cancer. Prostate 69(10): 1091-1100, 2009. PMID: 19350549. DOI: 10.1002/pros.20959

344 Qu X, Randhawa G, Friedman C, O'Hara-Larrivee S, Kroeger K, Dumpit R, True L, Vakar-Lopez F, Porter C, Vessella R, Nelson P and Fang M: A novel four-color fluorescence in situ hybridization assay for the detection of TMPRSS2 and ERG rearrangements in prostate cancer. Cancer Genet 206(1-2): 1-11, 2013. PMID: 23352841. DOI: 10.1016/j.cancergen.2012.12.004

345 Magi-Galluzzi C, Tsusuki T, Elson P, Simmerman K, LaFargue C, Esgueva R, Klein E, Rubin MA and Zhou M: TMPRSS2-ERG gene fusion prevalence and class are significantly different in prostate cancer of Caucasian, African-American and Japanese patients. Prostate 71(5): 489-497, 2011. PMID: 20878952. DOI: 10.1002/pros.21265

346 Song $\mathrm{C}$ and Chen $\mathrm{H}$ : Predictive significance of TMRPSS2-ERG fusion in prostate cancer: A meta-analysis. Cancer Cell Int 18: 177, 2018. PMID: 30459527. DOI: 10.1186/s12935-018-0672-2

347 Murphy SJ, Kosari F, Karnes RJ, Nasir A, Johnson SH, Gaitatzes AG, Smadbeck JB, Rangel LJ, Vasmatzis G and Cheville JC: Retention of interstitial genes between TMPRSS2 and ERG is associated with low-risk prostate cancer. Cancer Res 77(22): 6157-6167, 2017. PMID: 29127096. DOI: 10.1158/00085472.CAN-17-0529

348 Linn DE, Penney KL, Bronson RT, Mucci LA and Li Z: Deletion of interstitial genes between TMPRSS2 and ERG promotes prostate cancer progression. Cancer Res 76(7): 1869-1881, 2016. PMID: 26880803. DOI: 10.1158/0008-5472.CAN-15-1911

349 Pandey A, Ozaki K, Baumann H, Levin SD, Puel A, Farr AG, Ziegler SF, Leonard WJ and Lodish HF: Cloning of a receptor subunit required for signaling by thymic stromal lymphopoietin. Nat Immunol 1(1): 59-64, 2000. PMID: 10881176. DOI: $10.1038 / 76923$

350 Reche PA, Soumelis V, Gorman DM, Clifford T, Liu Mr, Travis M, Zurawski SM, Johnston J, Liu YJ, Spits H, de Waal Malefyt R, Kastelein RA and Bazan JF: Human thymic stromal lymphopoietin preferentially stimulates myeloid cells. J Immunol 167(1): 336-343, 2001. PMID: 11418668. DOI: 10.4049/ jimmunol.167.1.336

351 Tonozuka Y, Fujio K, Sugiyama T, Nosaka T, Hirai M and Kitamura T: Molecular cloning of a human novel type I cytokine receptor related to delta1/TSLPR. Cytogenet Cell Genet 93(1-2): 23-25, 2001. PMID: 11474172. DOI: 10.1159/000056941
352 Zhang W, Wang J, Wang Q, Chen G, Zhang J, Chen T, Wan T, Zhang Y and Cao X: Identification of a novel type I cytokine receptor CRL2 preferentially expressed by human dendritic cells and activated monocytes. Biochem Biophys Res Commun 281(4): 878-883, 2001. PMID: 11237741. DOI: 10.1006/bbrc.2001.4432

353 Cantagrel V, Lossi AM, Boulanger S, Depetris D, Mattei MG, Gecz J, Schwartz CE, Van Maldergem L and Villard L: Disruption of a new $\mathrm{X}$ linked gene highly expressed in brain in a family with two mentally retarded males. J Med Genet 41(10): 736-742, 2004. PMID: 15466006. DOI: 10.1136/jmg.2004.021626

354 Liu YJ: TSLP in epithelial cell and dendritic cell cross talk. Adv Immunol 101: 1-25, 2009. PMID: 19231591. DOI: 10.1016/ S0065-2776(08)01001-8

355 Zhong J, Sharma J, Raju R, Palapetta SM, Prasad TS, Huang TC, Yoda A, Tyner JW, van Bodegom D, Weinstock DM, Ziegler SF and Pandey A: TSLP signaling pathway map: A platform for analysis of TSLP-mediated signaling. Database (Oxford) 2014: bau007, 2014. PMID: 24573880. DOI: 10.1093/database/bau007

356 Marković I and Savvides SN: Modulation of signaling mediated by TSLP and IL-7 in inflammation, autoimmune diseases, and cancer. Front Immunol 11: 1557, 2020. PMID: 32849527. DOI: 10.3389/fimmu.2020.01557

357 Muppidi JR, Lu E and Cyster JG: The G protein-coupled receptor P2RY8 and follicular dendritic cells promote germinal center confinement of B cells, whereas S1PR3 can contribute to their dissemination. J Exp Med 212(13): 2213-2222, 2015. PMID: 26573295. DOI: $10.1084 /$ jem.20151250

$358 \mathrm{Lu}$ E and Cyster JG: G-protein coupled receptors and ligands that organize humoral immune responses. Immunol Rev 289(1): 158172, 2019. PMID: 30977196. DOI: 10.1111/imr.12743

359 Lu E, Wolfreys FD, Muppidi JR, Xu Y and Cyster JG: SGeranylgeranyl-L-glutathione is a ligand for human B cellconfinement receptor P2RY8. Nature 567(7747): 244-248, 2019. PMID: 30842656. DOI: 10.1038/s41586-019-1003-Z

360 Mullighan CG, Collins-Underwood JR, Phillips LA, Loudin MG, Liu W, Zhang J, Ma J, Coustan-Smith E, Harvey RC, Willman CL, Mikhail FM, Meyer J, Carroll AJ, Williams RT, Cheng J, Heerema NA, Basso G, Pession A, Pui CH, Raimondi SC, Hunger SP, Downing JR, Carroll WL and Rabin KR: Rearrangement of CRLF2 in B-progenitor- and Down syndromeassociated acute lymphoblastic leukemia. Nat Genet 41(11): 1243-1246, 2009. PMID: 19838194. DOI: 10.1038/ng.469

361 Russell LJ, Capasso M, Vater I, Akasaka T, Bernard OA, Calasanz MJ, Chandrasekaran T, Chapiro E, Gesk S, Griffiths M, Guttery DS, Haferlach C, Harder L, Heidenreich O, Irving J, Kearney L, Nguyen-Khac F, Machado L, Minto L, Majid A, Moorman AV, Morrison H, Rand V, Strefford JC, Schwab C, Tönnies H, Dyer MJ, Siebert R and Harrison CJ: Deregulated expression of cytokine receptor gene, CRLF2, is involved in lymphoid transformation in B-cell precursor acute lymphoblastic leukemia. Blood 114(13): 2688-2698, 2009. PMID: 19641190. DOI: 10.1182/blood-2009-03-208397

362 Cario G, Zimmermann M, Romey R, Gesk S, Vater I, Harbott J, Schrauder A, Moericke A, Izraeli S, Akasaka T, Dyer MJ, Siebert $\mathrm{R}$, Schrappe M and Stanulla M: Presence of the P2RY8-CRLF2 rearrangement is associated with a poor prognosis in non-highrisk precursor B-cell acute lymphoblastic leukemia in children treated according to the ALL-BFM 2000 protocol. Blood 115(26): 5393-5397, 2010. PMID: 20378752. DOI: 10.1182/ blood-2009-11-256131 
363 Morak M, Attarbaschi A, Fischer S, Nassimbeni C, Grausenburger R, Bastelberger S, Krentz S, Cario G, Kasper D, Schmitt K, Russell LJ, Pötschger U, Stanulla M, Eckert C, Mann G, Haas OA and Panzer-Grümayer R: Small sizes and indolent evolutionary dynamics challenge the potential role of P2RY8CRLF2-harboring clones as main relapse-driving force in childhood ALL. Blood 120(26): 5134-5142, 2012. PMID: 23091296. DOI: 10.1182/blood-2012-07-443218

364 Palmi C, Vendramini E, Silvestri D, Longinotti G, Frison D, Cario G, Shochat C, Stanulla M, Rossi V, Di Meglio AM, Villa T, Giarin E, Fazio G, Leszl A, Schrappe M, Basso G, Biondi A, Izraeli S, Conter V, Valsecchi MG, Cazzaniga $\mathrm{G}$ and Te Kronnie G: Poor prognosis for P2RY8-CRLF2 fusion but not for CRLF2 over-expression in children with intermediate risk B-cell precursor acute lymphoblastic leukemia. Leukemia 26(10): 22452253, 2012. PMID: 22484421. DOI: 10.1038/leu.2012.101

365 Vesely C, Frech C, Eckert C, Cario G, Mecklenbräuker A, Zur Stadt U, Nebral K, Kraler F, Fischer S, Attarbaschi A, Schuster M, Bock C, Cavé H, von Stackelberg A, Schrappe M, Horstmann MA, Mann G, Haas OA and Panzer-Grümayer R: Genomic and transcriptional landscape of P2RY8-CRLF2-positive childhood acute lymphoblastic leukemia. Leukemia 31(7): 1491-1501, 2017. PMID: 27899802. DOI: 10.1038/leu.2016.365
366 Panzer-Grümayer R, Köhrer S and Haas OA: The enigmatic role(s) of P2RY8-CRLF2. Oncotarget 8(57): 96466-96467, 2017. PMID: 29228539. DOI: 10.18632/oncotarget.22098

367 Potter N, Jones L, Blair H, Strehl S, Harrison CJ, Greaves M, Kearney L and Russell LJ: Single-cell analysis identifies CRLF2 rearrangements as both early and late events in Down syndrome and non-Down syndrome acute lymphoblastic leukaemia. Leukemia 33(4): 893-904, 2019. PMID: 30487598. DOI: $10.1038 / \mathrm{s} 41375-018-0297-4$
Received February 26, 2021

Revised March 15, 2021

Accepted March 16, 2021 